\title{
Prostanoid receptors in GtoPdb v.2021.2
}

Lucie Clapp ${ }^{1}$, Mark Giembycz ${ }^{2}$, Akos Heinemann ${ }^{3}$, Robert L. Jones ${ }^{4}$, Shuh Narumiya ${ }^{5}$, Xavier Norel $^{6}$, Yukihiko Sugimoto $^{7}$, David F. Woodward ${ }^{8}$ and Chengcan Yao $^{9}$

1. University College London, UK

2. University of Calgary, Canada

3. Otto Loewi Research Center (for Vascular Biology, Immunology and Inflammation), Austria

4. University of Strathclyde, UK

5. Kyoto University Faculty of Medicine, Japan

6. Laboratory for Vascular Translational Science, France

7. Kumamoto University, Japan

8. Allergan plc, USA

9. University of Edinburgh, UK

\begin{abstract}
Prostanoid receptors (nomenclature as agreed by the NC-IUPHAR Subcommittee on Prostanoid Receptors [694]) are activated by the endogenous ligands prostaglandins $\mathrm{PGD}_{2}, \mathrm{PGE}_{1}$, $\mathrm{PGE}_{2}, \mathrm{PGF}_{2 \alpha}, \mathrm{PGH}_{2}$, prostacyclin $\left[\mathrm{PGI}_{2}\right]$ and thromboxane $\mathrm{A}_{2}$. Differences and similarities between human and rodent prostanoid receptor orthologues, and their specific roles in pathophysiologic conditions are reviewed in [448]. Measurement of the potency of $\mathrm{PGI}_{2}$ and thromboxane $\mathrm{A}_{2}$ is hampered by their instability in physiological salt solution; they are often replaced by cicaprost and U46619, respectively, in receptor characterization studies.
\end{abstract}

\section{Contents}

This is a citation summary for Prostanoid receptors in the Guide to Pharmacology database (GtoPdb). It exists purely as an adjunct to the database to facilitate the recognition of citations to and from the database by citation analyzers. Readers will almost certainly want to visit the relevant sections of the database which are given here under database links.

GtoPdb is an expert-driven guide to pharmacological targets and the substances that act on them. GtoPdb is a reference work which is most usefully represented as an on-line database. As in any publication this work should be appropriately cited, and the papers it cites should also be recognized. This document provides a citation for the relevant parts of the database, and also provides a reference list for the research cited by those parts. For further details see [76].

Please note that the database version for the citations given in GtoPdb are to the most recent preceding version in which the family or its subfamilies and targets were substantially changed. The links below are to the current version. If you need to consult the cited version, rather than the most recent version, please contact the GtoPdb curators.

\section{Database links}

Prostanoid receptors

https://www.guidetopharmacology.org/GRAC/FamilyDisplayForward?familyId=58

Introduction to Prostanoid receptors

https://www.guidetopharmacology.org/GRAC/FamilyIntroductionForward?familyId=58

Receptors

$\mathrm{DP}_{1}$ receptor

https://www.guidetopharmacology.org/GRAC/ObjectDisplayForward?objectId=338

$\mathrm{DP}_{2}$ receptor

https://www.guidetopharmacology.org/GRAC/ObjectDisplayForward?objectId=339

$\mathrm{EP}_{1}$ receptor 
https://www.guidetopharmacology.org/GRAC/ObjectDisplayForward?objectId=340 $\mathrm{EP}_{2}$ receptor

https://www.guidetopharmacology.org/GRAC/ObjectDisplayForward?objectId=341 $\mathrm{EP}_{3}$ receptor

https://www.guidetopharmacology.org/GRAC/ObjectDisplayForward?objectId=342 $\mathrm{EP}_{4}$ receptor

https://www.guidetopharmacology.org/GRAC/ObjectDisplayForward?objectId=343 FP receptor

https://www.guidetopharmacology.org/GRAC/ObjectDisplayForward?objectId=344 IP receptor

https://www.guidetopharmacology.org/GRAC/ObjectDisplayForward?objectId=345 TP receptor

https://www.guidetopharmacology.org/GRAC/ObjectDisplayForward?objectId=346

\section{References}

1. Abe H, Takeshita T, Nagata K, Arita T, Endo Y, Fujita T, Takayama H, Kubo M and Sugamura K. (1999) Molecular cloning, chromosome mapping and characterization of the mouse CRTH2 gene, a putative member of the leukocyte chemoattractant receptor family. Gene 227: 71-7 [PMID:9931443]

2. Abe T, Takeuchi K, Takahashi N, Tsutsumi E, Taniyama Y and Abe K. (1995) Rat kidney thromboxane receptor: molecular cloning, signal transduction, and intrarenal expression localization. J Clin Invest 96: 657-64 [PMID:7635958]

3. Abramovitz M, Adam M, Boie Y, Carrière M, Denis D, Godbout C, Lamontagne S, Rochette C, Sawyer N and Tremblay NM et al.. (2000) The utilization of recombinant prostanoid receptors to determine the affinities and selectivities of prostaglandins and related analogs. Biochim Biophys Acta 1483: 285-93 [PMID:10634944]

4. Abramovitz M, Boie Y, Nguyen T, Rushmore TH, Bayne MA, Metters KM, Slipetz DM and Grygorczyk R. (1994) Cloning and expression of a cDNA for the human prostanoid FP receptor. $J$ Biol Chem 269: 2632-6 [PMID:8300593]

5. Adam M, Boie Y, Rushmore TH, Müller G, Bastien L, McKee KT, Metters KM and Abramovitz M. (1994) Cloning and expression of three isoforms of the human EP3 prostanoid receptor. FEBS Lett 338: 170-174 [PMID:8307176]

6. Adams JL, Smothers J, Srinivasan R and Hoos A. (2015) Big opportunities for small molecules in immuno-oncology. Nat Rev Drug Discov 14: 603-22 [PMID:26228631]

7. af Forselles KJ, Root J, Clarke T, Davey D, Aughton K, Dack K and Pullen N. (2011) In vitro and in vivo characterization of PF-04418948, a novel, potent and selective prostaglandin $\mathrm{EP}_{2}$ receptor antagonist. Br J Pharmacol 164: 1847-56 [PMID:21595651]

8. Ahmad AS, Maruyama T, Narumiya S and Doré S. (2013) PGE2 EP1 receptor deletion attenuates 6-OHDA-induced Parkinsonism in mice: old switch, new target. Neurotox Res 23: 260-6 [PMID:23385625]

9. Aihara E, Nomura Y, Sasaki Y, Ise F, Kita K and Takeuchi K. (2007) Involvement of prostaglandin E receptor EP3 subtype in duodenal bicarbonate secretion in rats. Life Sci $\mathbf{8 0}$ : 2446-53 [PMID:17512019]

10. Akhter MP, Cullen DM, Gong G and Recker RR. (2001) Bone biomechanical properties in prostaglandin EP1 and EP2 knockout mice. Bone 29: 121-5 [PMID:11502472]

11. Akhter MP, Cullen DM and Pan LC. (2006) Bone biomechanical properties in EP4 knockout mice. Calcif Tissue Int 78: 357-62 [PMID:16830205]

12. Allen IC, Hartney JM, Coffman TM, Penn RB, Wess J and Koller BH. (2006) Thromboxane A2 induces airway constriction through an M3 muscarinic acetylcholine receptor-dependent mechanism. Am J Physiol Lung Cell Mol Physiol 290: L526-33 [PMID:16243899]

13. Alvarez R, Eglen RM, Chang LF, Bruno JJ, Artis DR, Kluge AF and Whiting RL. (1991) Stimulation of prostaglandin $\mathrm{D}_{2}$ receptors on human platelets by analogs of prostacyclin. Prostaglandins 42: 105-119 [PMID:1775633]

14. Alvarez R, Taylor A, Fazzari JJ and Jacobs JR. (1981) Regulation of cyclic AMP metabolism in human platelets. Sequential activation of adenylate cyclase and cyclic AMP phosphodiesterase by prostaglandins. Mol Pharmacol 20: 302-9 [PMID:6272089]

15. Amano H, Hayashi I, Endo H, Kitasato H, Yamashina S, Maruyama T, Kobayashi M, Satoh K, Narita M and Sugimoto Y et al.. (2003) Host prostaglandin E(2)-EP3 signaling regulates tumorassociated angiogenesis and tumor growth. J Exp Med 197: 221-32 [PMID:12538661]

16. Amaradhi R, Banik A, Mohammed S, Patro V, Rojas A, Wang W, Motati DR, Dingledine R and Ganesh T. (2020) Potent, Selective, Water Soluble, Brain-Permeable EP2 Receptor Antagonist for Use in Central Nervous System Disease Models. J Med Chem 63: 1032-1050 [PMID:31904232]

17. An S, Yang J, So SW, Zeng L and Goetzl EJ. (1994) Isoforms of the EP3 subtype of human 
prostaglandin E2 receptor transduce both intracellular calcium and cAMP signals. Biochemistry 33: 14496-502 [PMID:7981210]

18. An S, Yang J, Xia M and Goetzl EJ. (1993) Cloning and expression of the EP2 subtype of human receptors for prostaglandin E2. Biochem Biophys Res Commun 197: 263-70 [PMID:8250933]

19. Ando $T$, Ichijo $T$, Katafuchi $T$ and Hori $T$. (1995) Intracerebroventricular injection of prostaglandin E2 increases splenic sympathetic nerve activity in rats. Am J Physiol 269: R662-8 [PMID:7573569]

20. Andoh T, Nishikawa Y, Yamaguchi-Miyamoto T, Nojima H, Narumiya S and Kuraishi Y. (2007) Thromboxane A2 induces itch-associated responses through TP receptors in the skin in mice. $J$ Invest Dermatol 127: 2042-7 [PMID:17429442]

21. Anthony TL, Lindsey JD, Aihara M and Weinreb RN. (2001) Detection of prostaglandin EP(1), EP(2), and FP receptor subtypes in human sclera. Invest Ophthalmol Vis Sci 42: 3182-6 [PMID:11726620]

22. Aoyama T, Liang B, Okamoto T, Matsusaki T, Nishijo K, Ishibe T, Yasura K, Nagayama S, Nakayama T and Nakamura T et al.. (2005) PGE2 signal through EP2 promotes the growth of articular chondrocytes. J Bone Miner Res 20: 377-89 [PMID:15746982]

23. Araki H, Ukawa H, Sugawa Y, Yagi K, Suzuki K and Takeuchi K. (2000) The roles of prostaglandin E receptor subtypes in the cytoprotective action of prostaglandin E2 in rat stomach. Aliment Pharmacol Ther 14 Suppl 1: 116-24 [PMID:10807413]

24. Arehart E, Stitham J, Asselbergs FW, Douville K, MacKenzie T, Fetalvero KM, Gleim S, Kasza Z, Rao Y and Martel L et al.. (2008) Acceleration of cardiovascular disease by a dysfunctional prostacyclin receptor mutation: potential implications for cyclooxygenase-2 inhibition. Circ Res 102: 986-93 [PMID:18323528]

25. Arima M and Fukuda T. (2011) Prostaglandin $\mathrm{D}_{2}$ and $\mathrm{T}(\mathrm{H}) 2$ inflammation in the pathogenesis of bronchial asthma. Korean J Intern Med 26: 8-18 [PMID:21437156]

26. Arimura A, Yasui K, Kishino J, Asanuma F, Hasegawa H, Kakudo S, Ohtani M and Arita H. (2001) Prevention of allergic inflammation by a novel prostaglandin receptor antagonist, S-5751.J Pharmacol Exp Ther 298: 411-9 [PMID:11454901]

27. Ariumi H, Takano Y, Masumi A, Takahashi S, Hirabara Y, Honda K, Saito R and Kamiya HO. (2002) Roles of the central prostaglandin EP3 receptors in cardiovascular regulation in rats. Neurosci Lett 324: 61-4 [PMID:11983295]

28. Armstrong RA, Humphrey PP and Lumley P. (1993) Characteristics of the binding of [3H]GR32191 to the thromboxane (TP-) receptor of human platelets. Br J Pharmacol 110: 539-47 [PMID:8242228]

29. Armstrong RA, Jones RL, MacDermot J and Wilson NH. (1986) Prostaglandin endoperoxide analogues which are both thromboxane receptor antagonists and prostacyclin mimetics. $\mathrm{Br} J$ Pharmacol 87: 543-51 [PMID:3026540]

30. Armstrong RA, Lawrence RA, Jones RL, Wilson NH and Collier A. (1989) Functional and ligand binding studies suggest heterogeneity of platelet prostacyclin receptors. BrJ Pharmacol 97: 657-668 [PMID:2474350]

31. Arns S, Gibe R, Moreau A, Monzur Morshed M and Young RN. (2012) Design and synthesis of novel bone-targeting dual-action pro-drugs for the treatment and reversal of osteoporosis. Bioorg Med Chem 20: 2131-40 [PMID:22341574]

32. Aronoff DM, Canetti C and Peters-Golden M. (2004) Prostaglandin E2 inhibits alveolar macrophage phagocytosis through an E-prostanoid 2 receptor-mediated increase in intracellular cyclic AMP. J Immunol 173: 559-65 [PMID:15210817]

33. Aronoff DM, Lewis C, Serezani CH, Eaton KA, Goel D, Phipps JC, Peters-Golden M and Mancuso P. (2009) E-prostanoid 3 receptor deletion improves pulmonary host defense and protects mice from death in severe Streptococcus pneumoniae infection. J Immunol 183: 2642-9 [PMID:19635910]

34. Arulkumaran S, Kandola MK, Hoffman B, Hanyaloglu AC, Johnson MR and Bennett PR. (2012) The roles of prostaglandin EP 1 and 3 receptors in the control of human myometrial contractility. J Clin Endocrinol Metab 97: 489-98 [PMID:22162473]

35. Asaki T, Hamamoto T, Sugiyama Y, Kuwano K and Kuwabara K. (2007) Structure-activity studies on diphenylpyrazine derivatives: a novel class of prostacyclin receptor agonists. Bioorg Med Chem 15: 6692-704 [PMID:17764960]

36. Asano K, Sagara H, Ichinose M, Hirata M, Nakajima A, Ortega H and Tohda Y. (2020) A Phase 2a Study of $\mathrm{DP}_{2}$ Antagonist GB001 for Asthma. J Allergy Clin Immunol Pract 8: 1275-1283.e1 [PMID:31778823]

37. Asbóth G, Phaneuf S, Europe-Finner GN, Toth M and Bernal AL. (1996) Prostaglandin E2 activates phospholipase $\mathrm{C}$ and elevates intracellular calcium in cultured myometrial cells: involvement of EP1 and EP3 receptor subtypes. Endocrinology 137: 2572-2579 [PMID:8641211]

38. Asbóth G, Phaneuf S and López Bernal AL. (1997) Prostaglandin E receptors in myometrial cells. Acta Physiol Hung 85: 39-50 [PMID:9530435]

39. Ashton AW, Mukherjee S, Nagajyothi FN, Huang H, Braunstein VL, Desruisseaux MS, Factor 
SM, Lopez L, Berman JW and Wittner M et al.. (2007) Thromboxane A2 is a key regulator of pathogenesis during Trypanosoma cruzi infection. J Exp Med 204: 929-40 [PMID:17420269]

40. Aso H, Ito S, Mori A, Suganuma N, Morioka M, Takahara N, Kondo M and Hasegawa Y. (2013) Differential regulation of airway smooth muscle cell migration by e-prostanoid receptor subtypes. Am J Respir Cell Mol Biol 48: 322-9 [PMID:23221043]

41. Attur M, Al-Mussawir HE, Patel J, Kitay A, Dave M, Palmer G, Pillinger MH and Abramson SB. (2008) Prostaglandin E2 exerts catabolic effects in osteoarthritis cartilage: evidence for signaling via the EP4 receptor. J Immunol 181: 5082-8 [PMID:18802112]

42. Audet M, White KL, Breton B, Zarzycka B, Han GW, Lu Y, Gati C, Batyuk A, Popov P and Velasquez J et al.. (2019) Crystal structure of misoprostol bound to the labor inducer prostaglandin $\mathrm{E}_{2}$ receptor. Nat Chem Biol 15: 11-17 [PMID:30510194]

43. Audoly LP, Ruan X, Wagner VA, Goulet JL, Tilley SL, Koller BH, Coffman TM and Arendshorst WJ. (2001) Role of EP(2) and EP(3) PGE(2) receptors in control of murine renal hemodynamics. Am J Physiol Heart Circ Physiol 280: H327-33 [PMID:11123248]

44. Audoly LP, Tilley SL, Goulet J, Key M, Nguyen M, Stock JL, McNeish JD, Koller BH and Coffman TM. (1999) Identification of specific EP receptors responsible for the hemodynamic effects of PGE2. Am J Physiol 277: H924-30 [PMID:10484412]

45. Ayabe S, Murata T, Maruyama T, Hori M and Ozaki H. (2009) Prostaglandin E2 induces contraction of liver myofibroblasts by activating EP3 and FP prostanoid receptors. $\mathrm{Br} J$ Pharmacol 156: 835-45 [PMID:19239477]

46. Ayer LM, Wilson SM, Traves SL, Proud D and Giembycz MA. (2008) 4,5-Dihydro-1H-imidazol-2yl)-[4-(4-isopropoxy-benzyl)-phenyl]-amine (RO1138452) is a selective, pseudo-irreversible orthosteric antagonist at the prostacyclin (IP)-receptor expressed by human airway epithelial cells: IP-receptor-mediated inhibition of CXCL9 and CXCL10 release. J Pharmacol Exp Ther 324: 815-26 [PMID:17962517]

47. Baba H, Kohno T, Moore KA and Woolf CJ. (2001) Direct activation of rat spinal dorsal horn neurons by prostaglandin E2. J Neurosci 21: 1750-6 [PMID:11222664]

48. Badzynska B and Sadowski J. (2008) Opposed effects of prostaglandin E2 on perfusion of rat renal cortex and medulla: interactions with the renin-angiotensin system. Exp Physiol 93: 1292302 [PMID:18586855]

49. Bastien L, Sawyer N, Grygorczyk R, Metters KM and Adam M. (1994) Cloning, functional expression, and characterization of the human prostaglandin E2 receptor EP2 subtype. J Biol Chem 269: 11873-7 [PMID:8163486]

50. Bateman ED, O'Brien C, Rugman P, Luke S, Ivanov S and Uddin M. (2018) Efficacy and safety of the CRTh2 antagonist AZD1981 as add-on therapy to inhaled corticosteroids and long-acting $\beta_{2}$ agonists in patients with atopic asthma. Drug Des Devel Ther 12: 1093-1106 [PMID:29765200]

51. Baxter GS, Clayton JK, Coleman RA, Marshall K, Sangha R and Senior J. (1995) Characterization of the prostanoid receptors mediating constriction and relaxation of human isolated uterine artery. Br J Pharmacol 116: 1692-6 [PMID:8564239]

52. Bayston T, Ramessur S, Reise J, Jones KG and Powell JT. (2003) Prostaglandin E2 receptors in abdominal aortic aneurysm and human aortic smooth muscle cells. J Vasc Surg 38: 354-9 [PMID:12891120]

53. Beck H, Thaler T, Meibom D, Meininghaus M, Jörißen H, Dietz L, Terjung C, Bairlein M, von Bühler C-J and Anlauf S et al.. (2020) Potent and Selective Human Prostaglandin F (FP) Receptor Antagonist (BAY-6672) for the Treatment of Idiopathic Pulmonary Fibrosis (IPF) $\mathrm{J} \mathrm{Med}$ Chem [PMID:32969660]

54. Belley A and Chadee K. (1999) Prostaglandin E(2) stimulates rat and human colonic mucin exocytosis via the EP(4) receptor. Gastroenterology 117: 1352-62 [PMID:10579976]

55. Belley M, Gallant M, Roy B, Houde K, Lachance N, Labelle M, Trimble LA, Chauret N, Li C and Sawyer N et al.. (2005) Structure-activity relationship studies on ortho-substituted cinnamic acids, a new class of selective EP(3) antagonists. Bioorg Med Chem Lett 15: 527-30 [PMID:15664806]

56. Benyahia C, Boukais K, Gomez I, Silverstein A, Clapp L, Fabre A, Danel C, Leséche G, Longrois D and Norel X. (2013) A comparative study of PGI2 mimetics used clinically on the vasorelaxation of human pulmonary arteries and veins, role of the DP-receptor. Prostaglandins Other Lipid Mediat 107: 48-55 [PMID:23850788]

57. Benyahia C, Gomez I, Kanyinda L, Boukais K, Danel C, Leséche G, Longrois D and Norel X. (2012) PGE(2) receptor (EP(4)) agonists: potent dilators of human bronchi and future asthma therapy? Pulm Pharmacol Ther 25: 115-8 [PMID:22244823]

58. Betz R, Lagercrantz J, Kedra D, Dumanski JP and Nordenskjöld A. (1999) Genomic structure, 5' flanking sequences, and precise localization in 1P31.1 of the human prostaglandin $F$ receptor gene. Biochem Biophys Res Commun 254: 413-6 [PMID:9918852]

59. Bexis S, McCormick PA and Docherty JR. (2008) Vascular actions of the prostacyclin receptor antagonist BAY 73-1449 in the portal hypertensive rat. Eur J Pharmacol 590: 322-6 [PMID:18603238] 
60. Bhattacherjee P, Mukhopadhyay P, Tilley SL, Koller BH, Geoghgan T and Paterson CA. (2002) Blood-aqueous barrier in prostaglandin EP2 receptor knockout mice. Ocul Immunol Inflamm 10: 187-96 [PMID:12789594]

61. Bilson HA, Mitchell DL and Ashby B. (2004) Human prostaglandin EP3 receptor isoforms show different agonist-induced internalization patterns. FEBS Lett 572: 271-5 [PMID:15304361]

62. Birrell MA, Maher SA, Buckley J, Dale N, Bonvini S, Raemdonck K, Pullen N, Giembycz MA and Belvisi MG. (2013) Selectivity profiling of the novel EP2 receptor antagonist, PF-04418948, in functional bioassay systems: atypical affinity at the guinea pig EP2 receptor. $\mathrm{Br} J$ Pharmacol 168: 129-38 [PMID:22747912]

63. Biswas S, Bhattacherjee P, Paterson CA, Maruyama T and Narumiya S. (2007) Modulation of ocular inflammatory responses by EP1 receptors in mice. Exp Eye Res 84: 39-43 [PMID:17052707]

64. Biswas S, Bhattacherjee P, Paterson CA, Tilley SL and Koller BH. (2006) Ocular inflammatory responses in the EP2 and EP4 receptor knockout mice. Ocul Immunol Inflamm 14: 157-63 [PMID:16766399]

65. Bley KR, Bhattacharya A, Daniels DV, Gever J, Jahangir A, O'Yang C, Smith S, Srinivasan D, Ford AP and Jett MF. (2006) RO1138452 and RO3244794: characterization of structurally distinct, potent and selective IP (prostacyclin) receptor antagonists. Br J Pharmacol 147: 335-45 [PMID:16331286]

66. Blouin M, Han Y, Burch J, Farand J, Mellon C, Gaudreault M, Wrona M, Lévesque JF, Denis D and Mathieu MC et al.. (2010) The discovery of 4-\{1-[(\{2,5-dimethyl-4-[4(trifluoromethyl)benzyl]-3-thienyl\} carbonyl)amino]cyclopropyl \} benzoic acid (MK-2894), a potent and selective prostaglandin E2 subtype 4 receptor antagonist. J Med Chem 53: 2227-38 [PMID:20163116]

67. Boie Y, Rushmore TH, Darmon-Goodwin A, Grygorczyk R, Slipetz DM, Metters KM and Abramovitz M. (1994) Cloning and expression of a cDNA for the human prostanoid IP receptor. $J$ Biol Chem 269: 12173-8 [PMID:7512962]

68. Boie Y, Sawyer N, Slipetz DM, Metters KM and Abramovitz M. (1995) Molecular cloning and characterization of the human prostanoid DP receptor. J Biol Chem 270: 18910-6 [PMID:7642548]

69. Boie Y, Stocco R, Sawyer N, Slipetz DM, Ungrin MD, Neuschäfer-Rube F, Püschel GP, Metters KM and Abramovitz M. (1997) Molecular cloning and characterization of the four rat prostaglandin E2 prostanoid receptor subtypes. Eur J Pharmacol 340: 227-41 [PMID:9537820]

70. Bondesen BA, Jones KA, Glasgow WC and Pavlath GK. (2007) Inhibition of myoblast migration by prostacyclin is associated with enhanced cell fusion. FASEB J 21: 3338-45 [PMID:17488951]

71. Breyer MD and Breyer RM. (2001) G protein-coupled prostanoid receptors and the kidney. Annu Rev Physiol 63: 579-605 [PMID:11181968]

72. Breyer MD, Davis L, Jacobson HR and Breyer RM. (1996) Differential localization of prostaglandin E receptor subtypes in human kidney. Am J Physiol 270: F912-8 [PMID:8928854]

73. Brittan JE, King CD and Stearns BA. (2011) DP2 ANTAGONIST AND USES THEREOF Patent number: WO2011085033.

74. Brouxhon S, Konger RL, VanBuskirk J, Sheu TJ, Ryan J, Erdle B, Almudevar A, Breyer RM, Scott $\mathrm{G}$ and Pentland AP. (2007) Deletion of prostaglandin E2 EP2 receptor protects against ultraviolet-induced carcinogenesis, but increases tumor aggressiveness. J Invest Dermatol 127: 439-46 [PMID:16977324]

75. Buckley J, Birrell MA, Maher SA, Nials AT, Clarke DL and Belvisi MG. (2011) EP4 receptor as a new target for bronchodilator therapy. Thorax 66: 1029-35 [PMID:21606476]

76. Buneman P, Christie G, Davies JA, Dimitrellou R, Harding SD, Pawson AJ, Sharman JL and Wu Y. (2020) Why data citation isn't working, and what to do about it Database 2020 [PMID:32367113]

77. Burgess LE, Clark CT, Cook A, Corrette CP, Delise RK, Doherty GA, Hunt KW and Romoff T. (2009) 6-substituted phenoxychroman carboxylic acid derivatives Patent number: WO2009158426A1.

78. Båtshake B, Nilsson C and Sundelin J. (1995) Molecular characterization of the mouse prostanoid EP1 receptor gene. Eur J Biochem 231: 809-14 [PMID:7649181]

79. Båtshake B, Nilsson C and Sundelin J. (1999) Structure and expression of the murine thromboxane A2 receptor gene. Biochem Biophys Res Commun 256: 391-7 [PMID:10079195]

80. Böhm E, Sturm GJ, Weiglhofer I, Sandig H, Shichijo M, McNamee A, Pease JE, Kollroser M, Peskar BA and Heinemann A. (2004) 11-Dehydro-thromboxane B2, a stable thromboxane metabolite, is a full agonist of chemoattractant receptor-homologous molecule expressed on TH2 cells (CRTH2) in human eosinophils and basophils. J Biol Chem 279: 7663-70 [PMID:14668348]

81. Caggiano AO and Kraig RP. (1999) Prostaglandin E receptor subtypes in cultured rat microglia and their role in reducing lipopolysaccharide-induced interleukin-1beta production. $J$ Neurochem 72: 565-75 [PMID:9930728]

82. Cameron KO, Lefker BA, Ke HZ, Li M, Zawistoski MP, Tjoa CM, Wright AS, DeNinno SL, 
Paralkar VM and Owen TA et al.. (2009) Discovery of CP-533536: an EP2 receptor selective prostaglandin E2 (PGE2) agonist that induces local bone formation. Bioorg Med Chem Lett 19: 2075-8 [PMID:19250823]

83. Candelario-Jalil E, Slawik H, Ridelis I, Waschbisch A, Akundi RS, Hüll M and Fiebich BL. (2005) Regional distribution of the prostaglandin E2 receptor EP1 in the rat brain: accumulation in Purkinje cells of the cerebellum. J Mol Neurosci 27: 303-10 [PMID:16280600]

84. Cao J, Shayibuzhati M, Tajima T, Kitazawa T and Taneike T. (2002) In vitro pharmacological characterization of the prostanoid receptor population in the non-pregnant porcine myometrium. Eur J Pharmacol 442: 115-23 [PMID:12020689]

85. Cao RY, St Amand T, Li X, Yoon SH, Wang CP, Song H, Maruyama T, Brown PM, Zelt DT and Funk CD. (2012) Prostaglandin receptor EP4 in abdominal aortic aneurysms. Am J Pathol 181: 313-21 [PMID:22595380]

86. Carrasco MP, Asbóth G, Phaneuf S and López Bernal A. (1997) Activation of the prostaglandin FP receptor in human granulosa cells. J Reprod Fertil 111: 309-17 [PMID:9462300]

87. Caselli G, Bonazzi A, Lanza M, Ferrari F, Maggioni D, Ferioli C, Giambelli R, Comi E, Zerbi S and Perrella $\mathrm{M}$ et al.. (2018) Pharmacological characterisation of CR6086, a potent prostaglandin $\mathrm{E}_{2}$ receptor 4 antagonist, as a new potential disease-modifying anti-rheumatic drug. Arthritis Res Ther 20: 39 [PMID:29490676]

88. Chan CL, Jones RL and Lau HY. (2000) Characterization of prostanoid receptors mediating inhibition of histamine release from anti-IgE-activated rat peritoneal mast cells. BrJ Pharmacol 129: 589-97 [PMID:10711359]

89. Chan EC, Dusting GJ, Guo N, Peshavariya HM, Taylor CJ, Dilley R, Narumiya S and Jiang F. (2010) Prostacyclin receptor suppresses cardiac fibrosis: role of CREB phosphorylation. J Mol Cell Cardiol 49: 176-85 [PMID:20403362]

90. Chang CS, Negishi M, Nakano T, Morizawa Y, Matsumura Y and Ichikawa A. (1997) 7,7Difluoroprostacyclin derivative, AFP-07, a highly selective and potent agonist for the prostacyclin receptor. Prostaglandins 53: 83-90 [PMID:9112287]

91. Chen Q, Muramoto K, Masaaki N, Ding Y, Yang H, Mackey M, Li W, Inoue Y, Ackermann K and Shirota $\mathrm{H}$ et al.. (2010) A novel antagonist of the prostaglandin E(2) EP(4) receptor inhibits Th1 differentiation and Th17 expansion and is orally active in arthritis models. BrJ Pharmacol 160: 292-310 [PMID:20423341]

92. Cheng K, Wu TJ, Wu KK, Sturino C, Metters K, Gottesdiener K, Wright SD, Wang Z, O'Neill G and Lai E et al.. (2006) Antagonism of the prostaglandin D2 receptor 1 suppresses nicotinic acid-induced vasodilation in mice and humans. Proc Natl Acad Sci USA 103: 6682-7 [PMID:16617107]

93. Cheng Y, Austin SC, Rocca B, Koller BH, Coffman TM, Grosser T, Lawson JA and FitzGerald GA. (2002) Role of prostacyclin in the cardiovascular response to thromboxane A2. Science 296: 539-41 [PMID:11964481]

94. Chevalier E, Stock J, Fisher T, Dupont M, Fric M, Fargeau H, Leport M, Soler S, Fabien S and Pruniaux MP et al.. (2005) Cutting edge: chemoattractant receptor-homologous molecule expressed on Th2 cells plays a restricting role on IL-5 production and eosinophil recruitment. $J$ Immunol 175: 2056-60 [PMID:16081770]

95. Chow KB, Wong YH and Wise H. (2001) Prostacyclin receptor-independent inhibition of phospholipase C activity by non-prostanoid prostacyclin mimetics. Br J Pharmacol 134: 1375-84 [PMID:11724742]

96. Cimetière B, Dubuffet T, Muller O, Descombes JJ, Simonet S, Laubie M, Verbeuren TJ and Lavielle G. (1998) Synthesis and biological evaluation of new tetrahydronaphthalene derivatives as thromboxane receptor antagonists. Bioorg Med Chem Lett 8: 1375-80 [PMID:9871769]

97. Cipollone F, Fazia ML, Iezzi A, Cuccurullo C, De Cesare D, Ucchino S, Spigonardo F, Marchetti A, Buttitta F and Paloscia L et al.. (2005) Association between prostaglandin E receptor subtype EP4 overexpression and unstable phenotype in atherosclerotic plaques in human. Arterioscler Thromb Vasc Biol 25: 1925-31 [PMID:16020747]

98. Cirillo R, Tos EG, Page P, Missotten M, Quattropani A, Scheer A, Schwarz MK and Chollet A. (2007) Arrest of preterm labor in rat and mouse by an oral and selective nonprostanoid antagonist of the prostaglandin F2alpha receptor (FP). Am J Obstet Gynecol 197: 54.e1-9 [PMID:17618756]

99. Clapp LH and Gurung R. (2015) The mechanistic basis of prostacyclin and its stable analogues in pulmonary arterial hypertension: Role of membrane versus nuclear receptors. Prostaglandins Other Lipid Mediat 120: 56-71 [PMID:25917921]

100. Clark P, Rowland SE, Denis D, Mathieu MC, Stocco R, Poirier H, Burch J, Han Y, Audoly L and Therien AG et al.. (2008) MF498 [N-\{[4-(5,9-Diethoxy-6-oxo-6,8-dihydro-7H-pyrrolo[3,4g]quinolin-7-yl)-3-methylbenzyl]sulfonyl \}-2-(2-methoxyphenyl)acetamide], a selective E prostanoid receptor 4 antagonist, relieves joint inflammation and pain in rodent models of rheumatoid and osteoarthritis. J Pharmacol Exp Ther 325: 425-34 [PMID:18287210]

101. Clarke DL, Belvisi MG, Catley MC, Yacoub MH, Newton R and Giembycz MA. (2004) 
Identification in human airways smooth muscle cells of the prostanoid receptor and signalling pathway through which PGE2 inhibits the release of GM-CSF. Br J Pharmacol 141: 1141-50 [PMID:15023863]

102. Clarke DL, Belvisi MG, Smith SJ, Hardaker E, Yacoub MH, Meja KK, Newton R, Slater DM and Giembycz MA. (2005) Prostanoid receptor expression by human airway smooth muscle cells and regulation of the secretion of granulocyte colony-stimulating factor. Am J Physiol Lung Cell Mol Physiol 288: L238-50 [PMID:15640521]

103. Clarke DL, Giembycz MA, Patel HJ and Belvisi MG. (2004) E-ring 8-isoprostanes inhibit ACh release from parasympathetic nerves innervating guinea-pig trachea through agonism of prostanoid receptors of the EP3-subtype. Br J Pharmacol 141: 600-9 [PMID:14744812]

104. Coleman RA, Kennedy I, Humphrey PPA, Bunce K and Lumley P. (1990) Prostanoids and their receptors. In Comprehensive Medicinal Chemistry Edited by Hansch C, Sammes PG, Taylor JB: Pergamon Press: 643-714 [ISBN: 0080370616]

105. Coleman RA, Kennedy I and Sheldrick RL. (1987) New evidence with selective agonists and antagonists for the subclassification of PGE2-sensitive (EP) receptors. Adv Prostaglandin Thromboxane Leukot Res 17A: 467-70 [PMID:2889338]

106. Coleman RA and Sheldrick RL. (1989) Prostanoid-induced contraction of human bronchial smooth muscle is mediated by TP-receptors. Br J Pharmacol 96: 688-692 [PMID:2720298]

107. Coleman RA, Smith WL and Narumiya S. (1994) International Union of Pharmacology classification of prostanoid receptors: properties, distribution, and structure of the receptors and their subtypes. Pharmacol Rev 46: 205-29 [PMID:7938166]

108. Coleman RA, Woodrooffe AJ, Clark KL, Toris CB, Fan S, Wang JW and Woodward DF. (2019) The affinity, intrinsic activity and selectivity of a structurally novel $\mathrm{EP}_{2}$ receptor agonist at human prostanoid receptors. Br J Pharmacol 176: 687-698 [PMID:30341781]

109. Cooper B and Ahern D. (1979) Characterization of the platelet prostaglandin D2 receptor. Loss of prostaglandin D2 receptors in platelets of patients with myeloproliferative disorders. J Clin Invest 64: 586-90 [PMID:222813]

110. Crosignani S, Jorand-Lebrun C, Campbell G, Prêtre A, Grippi-Vallotton T, Quattropani A, Bouscary-Desforges G, Bombrun A, Missotten M and Humbert Y et al.. (2011) Discovery of a Novel Series of CRTH2 (DP2) Receptor Antagonists Devoid of Carboxylic Acids. ACS Med Chem Lett 2: 938-42 [PMID:24900284]

111. Crowston JG, Lindsey JD, Aihara M and Weinreb RN. (2004) Effect of latanoprost on intraocular pressure in mice lacking the prostaglandin FP receptor. Invest Ophthalmol Vis Sci 45: 3555-9 [PMID:15452062]

112. Crowston JG, Lindsey JD, Morris CA, Wheeler L, Medeiros FA and Weinreb RN. (2005) Effect of bimatoprost on intraocular pressure in prostaglandin FP receptor knockout mice. Invest Ophthalmol Vis Sci 46: 4571-7 [PMID:16303950]

113. Croy BA, Chantakru S, Narumiya S, Ichikawa A and Sugimoto Y. (2000) Prolonged gestation does not extend survival of uterine natural killer lymphocytes in mice deleted in the receptor for prostaglandin F2alpha. J Reprod Immunol 46: 125-9 [PMID:10706943]

114. Cyphert JM, Allen IC, Church RJ, Latour AM, Snouwaert JN, Coffman TM and Koller BH. (2012) Allergic inflammation induces a persistent mechanistic switch in thromboxane-mediated airway constriction in the mouse. Am J Physiol Lung Cell Mol Physiol 302: L140-51 [PMID:21984570]

115. Davis TL and Sharif NA. (2000) Pharmacological characterization of [(3)H]-prostaglandin E(2) binding to the cloned human EP(4) prostanoid receptor. Br J Pharmacol 130: 1919-1926 [PMID:10952683]

116. Diamond JM, Akimova T, Kazi A, Shah RJ, Cantu E, Feng R, Levine MH, Kawut SM, Meyer NJ and Lee JC et al.. (2014) Genetic variation in the prostaglandin E2 pathway is associated with primary graft dysfunction. Am J Respir Crit Care Med 189: 567-75 [PMID:24467603]

117. Ding M, Kinoshita Y, Kishi K, Nakata H, Hassan S, Kawanami C, Sugimoto Y, Katsuyama M, Negishi M and Narumiya S et al.. (1997) Distribution of prostaglandin E receptors in the rat gastrointestinal tract. Prostaglandins 53: 199-216 [PMID:9206801]

118. Dong YJ, Jones RL and Wilson NH. (1986) Prostaglandin E receptor subtypes in smooth muscle: agonist activities of stable prostacyclin analogues. Br J Pharmacol 87: 97-107 [PMID:2420404]

119. Downey JD, Sanders CR and Breyer RM. (2011) Evidence for the presence of a critical disulfide bond in the mouse EP3y receptor. Prostaglandins Other Lipid Mediat 94: 53-8 [PMID:21236356]

120. Duffin R, O'Connor RA, Crittenden S, Forster T, Yu C, Zheng X, Smyth D, Robb CT, Rossi F and Skouras C et al.. (2016) Prostaglandin E2 constrains systemic inflammation through an innate lymphoid cell-IL-22 axis. Science 351: 1333-8 [PMID:26989254]

121. El-Nefiawy N, Abdel-Hakim K, Kanayama N and Terao T. (2005) Role of prostaglandin E2 receptor subtypes in ovarian follicle growth in the rat in vivo. Correlation with interleukin-8 and neutrophils. Histol Histopathol 20: 825-31 [PMID:15944932]

122. Esaki Y, Li Y, Sakata D, Yao C, Segi-Nishida E, Matsuoka T, Fukuda K and Narumiya S. (2010) Dual roles of PGE2-EP4 signaling in mouse experimental autoimmune encephalomyelitis. Proc Natl Acad Sci USA 107: 12233-8 [PMID:20566843] 
123. Exner HJ and Schlicker E. (1995) Prostanoid receptors of the EP3 subtype mediate the inhibitory effect of prostaglandin E2 on noradrenaline release in the mouse brain cortex. Naunyn Schmiedebergs Arch Pharmacol 351: 46-52 [PMID:7715741]

124. Fabre JE, Nguyen M, Athirakul K, Coggins K, McNeish JD, Austin S, Parise LK, FitzGerald GA, Coffman TM and Koller BH. (2001) Activation of the murine EP3 receptor for PGE2 inhibits cAMP production and promotes platelet aggregation. J Clin Invest 107: 603-10 [PMID:11238561]

125. Facemire CS, Nguyen M, Jania L, Beierwaltes WH, Kim HS, Koller BH and Coffman TM. (2011) A major role for the EP4 receptor in regulation of renin. Am J Physiol Renal Physiol 301: F103541 [PMID:21835766]

126. Falcetti E, Hall SM, Phillips PG, Patel J, Morrell NW, Haworth SG and Clapp LH. (2010) Smooth muscle proliferation and role of the prostacyclin (IP) receptor in idiopathic pulmonary arterial hypertension. Am J Respir Crit Care Med 182: 1161-70 [PMID:20622039]

127. Fan H, Chen S, Yuan X, Han S, Zhang H, Xia W, Xu Y, Zhao Q and Wu B. (2019) Structural basis for ligand recognition of the human thromboxane $A_{2}$ receptor. Nat Chem Biol 15: 27-33 [PMID:30510189]

128. Feng C, Beller EM, Bagga S and Boyce JA. (2006) Human mast cells express multiple EP receptors for prostaglandin E2 that differentially modulate activation responses. Blood 107: 3243-50 [PMID:16357326]

129. Fennekohl A, Sugimoto Y, Segi E, Maruyama T, Ichikawa A and Püschel GP. (2002) Contribution of the two Gs-coupled PGE2-receptors EP2-receptor and EP4-receptor to the inhibition by PGE2 of the LPS-induced TNFalpha-formation in Kupffer cells from EP2-or EP4-receptor-deficient mice. Pivotal role for the EP4-receptor in wild type Kupffer cells. J Hepatol 36: 328-34 [PMID:11867175]

130. Feoktistov I, Breyer RM and Biaggioni I. (1997) Prostanoid receptor with a novel pharmacological profile in human erythroleukemia cells. Biochem Pharmacol 54: 917-26 [PMID:9354592]

131. Fernandes B and Crankshaw D. (1995) Functional characterization of the prostanoid DP receptor in human myometrium. Eur J Pharmacol 283: 73-81 [PMID:7498323]

132. Fillion D, Devost D, Sleno R, Inoue A and Hébert TE. (2019) Asymmetric Recruitment of $\beta$ Arrestin1/2 by the Angiotensin II Type I and Prostaglandin F2 $\alpha$ Receptor Dimer. Front Endocrinol (Lausanne) 10: 162 [PMID:30936850]

133. Fleming EF, Athirakul K, Oliverio MI, Key M, Goulet J, Koller BH and Coffman TM. (1998) Urinary concentrating function in mice lacking EP3 receptors for prostaglandin E2. Am J Physiol 275: F955-61 [PMID:9843913]

134. Foord SM, Marks B, Stolz M, Bufflier E, Fraser NJ and Lee MG. (1996) The structure of the prostaglandin EP4 receptor gene and related pseudogenes. Genomics 35: 182-8 [PMID:8661119]

135. Fortner CN, Breyer RM and Paul RJ. (2001) EP2 receptors mediate airway relaxation to substance P, ATP, and PGE2. Am J Physiol Lung Cell Mol Physiol 281: L469-74 [PMID:11435222]

136. Foudi N, Gomez I, Benyahia C, Longrois D and Norel X. (2012) Prostaglandin E2 receptor subtypes in human blood and vascular cells. Eur J Pharmacol 695: 1-6 [PMID:22964467]

137. Foudi N, Kotelevets L, Gomez I, Louedec L, Longrois D, Chastre E and Norel X. (2011) Differential reactivity of human mammary artery and saphenous vein to prostaglandin $\mathrm{E}(2)$ : implication for cardiovascular grafts. Br J Pharmacol 163: 826-34 [PMID:21323896]

138. Foudi N, Kotelevets L, Louedec L, Leséche G, Henin D, Chastre E and Norel X. (2008) Vasorelaxation induced by prostaglandin E2 in human pulmonary vein: role of the EP4 receptor subtype. Br J Pharmacol 154: 1631-9 [PMID:18516068]

139. Fox SC, May JA, Johnson A, Hermann D, Strieter D, Hartman D and Heptinstall S. (2013) Effects on platelet function of an EP3 receptor antagonist used alone and in combination with a P2Y12 antagonist both in-vitro and ex-vivo in human volunteers. Platelets 24: 392-400 [PMID:22866894]

140. Francois H, Athirakul K, Howell D, Dash R, Mao L, Kim HS, Rockman HA, Fitzgerald GA, Koller BH and Coffman TM. (2005) Prostacyclin protects against elevated blood pressure and cardiac fibrosis. Cell Metab 2: 201-7 [PMID:16154102]

141. Francois H, Makhanova N, Ruiz P, Ellison J, Mao L, Rockman HA and Coffman TM. (2008) A role for the thromboxane receptor in L-NAME hypertension. Am J Physiol Renal Physiol 295: F1096102 [PMID:18684890]

142. Fretz H, Valdenaire A, Pothier J, Hilpert K, Gnerre C, Peter O, Leroy X and Riederer MA. (2013) Identification of 2-(2-(1-naphthoyl)-8-fluoro-3,4-dihydro-1H-pyrido[4,3-b]indol-5(2H)-yl)acetic acid (setipiprant/ACT-129968), a potent, selective, and orally bioavailable chemoattractant receptor-homologous molecule expressed on Th2 cells (CRTH2) antagonist. J Med Chem 56: 4899-911 [PMID:23721423]

143. Friel AM, O'Reilly MW, Sexton DJ and Morrison JJ. (2005) Specific PGF(2alpha) receptor (FP) 
antagonism and human uterine contractility in vitro. BJOG 112: 1034-1042 [PMID:16045514]

144. Fujino H, Salvi S and Regan JW. (2005) Differential regulation of phosphorylation of the cAMP response element-binding protein after activation of EP2 and EP4 prostanoid receptors by prostaglandin E2. Mol Pharmacol 68: 251-9 [PMID:15855407]

145. Fujino H, Srinivasan D, Pierce KL and Regan JW. (2000) Differential regulation of prostaglandin F(2alpha) receptor isoforms by protein kinase C. Mol Pharmacol 57: 353-8 [PMID:10648645]

146. Fujino H, West KA and Regan JW. (2002) Phosphorylation of glycogen synthase kinase-3 and stimulation of T-cell factor signaling following activation of EP2 and EP4 prostanoid receptors by prostaglandin E2. J Biol Chem 277: 2614-9 [PMID:11706038]

147. Fujino H, Xu W and Regan JW. (2003) Prostaglandin E2 induced functional expression of early growth response factor-1 by EP4, but not EP2, prostanoid receptors via the phosphatidylinositol 3-kinase and extracellular signal-regulated kinases. J Biol Chem 278: 12151-6 [PMID:12566441]

148. Fukunaga M, Makita N, Roberts 2nd LJ, Morrow JD, Takahashi K and Badr KF. (1993) Evidence for the existence of F2-isoprostane receptors on rat vascular smooth muscle cells. Am J Physiol 264: C1619-24 [PMID:8333509]

149. Fullerton DA, Agrafojo J and McIntyre Jr RC. (1996) Pulmonary vascular smooth muscle relaxation by cAMP-mediated pathways. J Surg Res 61: 444-8 [PMID:8656622]

150. Funk CD, Furci L, FitzGerald GA, Grygorczyk R, Rochette C, Bayne MA, Abramovitz M, Adam M and Metters KM. (1993) Cloning and expression of a cDNA for the human prostaglandin E receptor EP1 subtype. J Biol Chem 268: 26767-72 [PMID:8253813]

151. Furuyashiki T and Narumiya S. (2009) Roles of prostaglandin E receptors in stress responses. Curr Opin Pharmacol 9: 31-8 [PMID:19157987]

152. Gallant M, Belley M, Carrière MC, Chateauneuf A, Denis D, Lachance N, Lamontagne S, Metters KM, Sawyer N and Slipetz D et al.. (2003) Structure-activity relationship of triaryl propionic acid analogues on the human EP3 prostanoid receptor. Bioorg Med Chem Lett 13: 3813-6 [PMID:14552786]

153. Gallant M, Carrière MC, Chateauneuf A, Denis D, Gareau Y, Godbout C, Greig G, Juteau H, Lachance $\mathrm{N}$ and Lacombe $\mathrm{P}$ et al.. (2002) Structure-activity relationship of biaryl acylsulfonamide analogues on the human EP(3) prostanoid receptor. Bioorg Med Chem Lett 12 : 2583-6 [PMID:12182865]

154. Gallant MA, Slipetz D, Hamelin E, Rochdi MD, Talbot S, de Brum-Fernandes AJ and Parent JL. (2007) Differential regulation of the signaling and trafficking of the two prostaglandin D2 receptors, prostanoid DP receptor and CRTH2. Eur J Pharmacol 557: 115-23 [PMID:17207480]

155. Ganesh T, Jiang J and Dingledine R. (2014) Development of second generation EP2 antagonists with high selectivity. Eur J Med Chem 82: 521-35 [PMID:24937185]

156. Ganesh T, Jiang J, Shashidharamurthy R and Dingledine R. (2013) Discovery and characterization of carbamothioylacrylamides as EP2 selective antagonists. ACS Med Chem Lett 4: 616-621 [PMID:23914286]

157. Gannon AM and Kinsella BT. (2008) Regulation of the human thromboxane A2 receptor gene by Sp1, Egr1, NF-E2, GATA-1, and Ets-1 in megakaryocytes. J Lipid Res 49: 2590-604 [PMID:18698092]

158. Gazi L, Gyles S, Rose J, Lees S, Allan C, Xue L, Jassal R, Speight G, Gamble V and Pettipher R. (2005) Delta12-prostaglandin D2 is a potent and selective CRTH2 receptor agonist and causes activation of human eosinophils and Th2 lymphocytes. Prostaglandins Other Lipid Mediat 75: 153-67 [PMID:15789622]

159. Gervais FG, Cruz RP, Chateauneuf A, Gale S, Sawyer N, Nantel F, Metters KM and O'neill GP. (2001) Selective modulation of chemokinesis, degranulation, and apoptosis in eosinophils through the PGD2 receptors CRTH2 and DP. J Allergy Clin Immunol 108: 982-8 [PMID:11742277]

160. Gervais FG, Morello JP, Beaulieu C, Sawyer N, Denis D, Greig G, Malebranche AD and O'Neill GP. (2005) Identification of a potent and selective synthetic agonist at the CRTH2 receptor. Mol Pharmacol 67: 1834-9 [PMID:15755909]

161. Giblin GM, Bit RA, Brown SH, Chaignot HM, Chowdhury A, Chessell IP, Clayton NM, Coleman T, Hall A and Hammond B et al.. (2007) The discovery of 6-[2-(5-chloro-2- $\{[(2,4-$ difluorophenyl)methyl]oxy\} phenyl)-1-cyclopenten-1-yl]-2-pyridinecarboxylic acid, GW848687X, a potent and selective prostaglandin EP1 receptor antagonist for the treatment of inflammatory pain. Bioorg Med Chem Lett 17: 385-9 [PMID:17084082]

162. Giguère V, Gallant MA, de Brum-Fernandes AJ and Parent JL. (2004) Role of extracellular cysteine residues in dimerization/oligomerization of the human prostacyclin receptor. Eur $J$ Pharmacol 494: 11-22 [PMID:15194446]

163. Giles H, Leff P, Bolofo ML, Kelly MG and Robertson AD. (1989) The classification of prostaglandin DP-receptors in platelets and vasculature using BW A868C, a novel, selective, and potent competitive antagonist. Br J Pharmacol 96: 291-300 [PMID:2924081]

164. Glas J, Seiderer J, Czamara D, Pasciuto G, Diegelmann J, Wetzke M, Olszak T, Wolf C, MüllerMyhsok B and Balschun T et al.. (2012) PTGER4 expression-modulating polymorphisms in the 
5p13.1 region predispose to Crohn's disease and affect NF-kB and XBP1 binding sites. PLoS One 7: e52873 [PMID:23300802]

165. Gomez I, Foudi N, Longrois D and Norel X. (2013) The role of prostaglandin E2 in human vascular inflammation. Prostaglandins Leukot Essent Fatty Acids 89: 55-63 [PMID:23756023]

166. Gray T, Nettesheim P, Loftin C, Koo JS, Bonner J, Peddada S and Langenbach R. (2004) Interleukin-1beta-induced mucin production in human airway epithelium is mediated by cyclooxygenase-2, prostaglandin E2 receptors, and cyclic AMP-protein kinase A signaling. Mol Pharmacol 66: 337-46 [PMID:15266025]

167. Gresele P, Arnout J, Deckmyn H, Huybrechts E, Pieters G and Vermylen J. (1987) Role of proaggregatory and antiaggregatory prostaglandins in hemostasis. Studies with combined thromboxane synthase inhibition and thromboxane receptor antagonism. J Clin Invest 80: 143545 [PMID:2960694]

168. Griffin BW, Klimko P, Crider JY and Sharif NA. (1999) AL-8810: a novel prostaglandin F2 alpha analog with selective antagonist effects at the prostaglandin F2 alpha (FP) receptor. $J$ Pharmacol Exp Ther 290: 1278-84 [PMID:10454504]

169. Grisaru-Granovsky S, Altarescu G, Finci S, Weintraub A, Tevet A, Samueloff A and Schimmel MS. (2010) Prostanoid DP receptor (PTGDR) variants in mothers with post-coital associated preterm births: preliminary observations. J Perinatol 30: 33-7 [PMID:19710676]

170. Gross S, Tilly P, Hentsch D, Vonesch JL and Fabre JE. (2007) Vascular wall-produced prostaglandin E2 exacerbates arterial thrombosis and atherothrombosis through platelet EP3 receptors. J Exp Med 204: 311-20 [PMID:17242161]

171. Grosser T, Yu Y and Fitzgerald GA. (2010) Emotion recollected in tranquility: lessons learned from the COX-2 saga. Annu Rev Med 61: 17-33 [PMID:20059330]

172. Grygorczyk R, Abramovitz M, Boie Y, Bastien L and Adam M. (1995) Detection of adenylate cyclase-coupled receptors in Xenopus oocytes by coexpression with cystic fibrosis transmembrane conductance regulator. Anal Biochem 227: 27-31 [PMID:7545356]

173. Guan Y, Zhang Y, Wu J, Qi Z, Yang G, Dou D, Gao Y, Chen L, Zhang X and Davis LS et al.. (2007) Antihypertensive effects of selective prostaglandin E2 receptor subtype 1 targeting. J Clin Invest 117: 2496-505 [PMID:17710229]

174. Guo M, Pascual RM, Wang S, Fontana MF, Valancius CA, Panettieri Jr RA, Tilley SL and Penn RB. (2005) Cytokines regulate beta-2-adrenergic receptor responsiveness in airway smooth muscle via multiple PKA- and EP2 receptor-dependent mechanisms. Biochemistry 44: 13771-82 [PMID:16229467]

175. Géhin M, Strasser DS, Zisowsky J, Farine H, Groenen PM, Dingemanse J and Sidharta PN. (2015) A novel CRTH2 antagonist: Single- and multiple-dose tolerability, pharmacokinetics, and pharmacodynamics of ACT-453859 in healthy subjects. J Clin Pharmacol 55: 787-97 [PMID:25655470]

176. Göggel R, Hoffman S, Nüsing R, Narumiya S and Uhlig S. (2002) Platelet-activating factorinduced pulmonary edema is partly mediated by prostaglandin E(2), E-prostanoid 3-receptors, and potassium channels. Am J Respir Crit Care Med 166: 657-62 [PMID:12204861]

177. Günther J, Schulte K, Wenzel D, Malinowska B and Schlicker E. (2010) Prostaglandins of the E series inhibit monoamine release via EP3 receptors: proof with the competitive EP3 receptor antagonist L-826,266. Naunyn Schmiedebergs Arch Pharmacol 381: 21-31 [PMID:20012265]

178. Hallinan EA, Stapelfeld A, and Reichman M. (1994) 8-chlorodibenz[b,f][1,4]oxazepine-10(11H)carboxylic acid,2-[3-[2-(furanylmethyl)thio]-1-oxopropyl]hydrazide (SC-51322): A potent PGE2 antagonist and analgesic. Bioorg Med Chem Lett 4: 509-514

179. Halushka PV, Kochel PJ and Mais DE. (1987) Binding of thromboxane A2/prostaglandin H2 agonists to human platelets. Br J Pharmacol 91: 223-7 [PMID:3594077]

180. Hamaguchi K, Yamamoto N, Nakagawa T, Furuyashiki T, Narumiya S and Ito J. (2012) Role of PGE-type receptor 4 in auditory function and noise-induced hearing loss in mice. Neuropharmacology 62: 1841-7 [PMID:22198478]

181. Hamanaka N, Takahashi K, Nagao Y, Torisu K, Tokumoto H and Kondo K. (1995) Molecular design of novel $\mathrm{PGI}_{2}$ agonists without PG skeleton. Bioorg Med Chem Lett 5: 1065-1070

182. Hanada R, Leibbrandt A, Hanada T, Kitaoka S, Furuyashiki T, Fujihara H, Trichereau J, Paolino M, Qadri F and Plehm R et al.. (2009) Central control of fever and female body temperature by RANKL/RANK. Nature 462: 505-9 [PMID:19940926]

183. Hara A, Yuhki K, Fujino T, Yamada T, Takayama K, Kuriyama S, Takahata O, Karibe H, Okada Y and Xiao CY et al.. (2005) Augmented cardiac hypertrophy in response to pressure overload in mice lacking the prostaglandin I2 receptor. Circulation 112: 84-92 [PMID:15983244]

184. Hashimoto K, Graham BS, Geraci MW, FitzGerald GA, Egan K, Zhou W, Goleniewska K, O'Neal JF, Morrow JD and Durbin RK et al.. (2004) Signaling through the prostaglandin I2 receptor IP protects against respiratory syncytial virus-induced illness. J Virol 78: 10303-9 [PMID:15367596]

185. Hata AN, Lybrand TP and Breyer RM. (2005) Identification of determinants of ligand binding affinity and selectivity in the prostaglandin D2 receptor CRTH2. J Biol Chem 280: 32442-32451 
[PMID:16030019]

186. Hata AN, Zent R, Breyer MD and Breyer RM. (2003) Expression and molecular pharmacology of the mouse CRTH2 receptor. J Pharmacol Exp Ther 306: 463-70 [PMID:12721327]

187. Hattori K, Tanaka A, Okitsu O, Tabuchi S, Taniguchi K, Nishio M, Koyama S, Higaki M, Seki J and Sakane K. (2005) Discovery of diphenylcarbamate derivatives as highly potent and selective IP receptor agonists: orally active prostacyclin mimetics. Part 3. Bioorg Med Chem Lett 15: 3091-5 [PMID:15914004]

188. Hattori R, Shimizu S, Majima Y and Shimizu T. (2008) EP4 agonist inhibits lipopolysaccharideinduced mucus secretion in airway epithelial cells. Ann Otol Rhinol Laryngol 117: 51-8 [PMID:18254372]

189. Hattori R, Shimizu S, Majima Y and Shimizu T. (2009) Prostaglandin E2 receptor EP2, EP3, and EP4 agonists inhibit antigen-induced mucus hypersecretion in the nasal epithelium of sensitized rats. Ann Otol Rhinol Laryngol 118: 536-41 [PMID:19708495]

190. Haye-Legrand I, Bourdillat B, Labat C, Cerrina J, Norel X, Benveniste J and Brink C. (1987) Relaxation of isolated human pulmonary muscle preparations with prostacyclin (PGI2) and its analogs. Prostaglandins 33: 845-54 [PMID:2445003]

191. Hedberg A, Hall SE, Ogletree ML, Harris DN and Liu EC. (1988) Characterization of [5,6-3H]SQ 29,548 as a high affinity radioligand, binding to thromboxane A2/prostaglandin H2-receptors in human platelets. J Pharmacol Exp Ther 245: 786-92 [PMID:2968449]

192. Heptinstall S, Espinosa DI, Manolopoulos P, Glenn JR, White AE, Johnson A, Dovlatova N, Fox SC, May JA and Hermann D et al.. (2008) DG-041 inhibits the EP3 prostanoid receptor--a new target for inhibition of platelet function in atherothrombotic disease. Platelets 19: 605-13 [PMID:19012178]

193. Hervé M, Angeli V, Pinzar E, Wintjens R, Faveeuw C, Narumiya S, Capron A, Urade Y, Capron M, Riveau G and Trottein F. (2003) Pivotal roles of the parasite PGD2 synthase and of the host D prostanoid receptor 1 in schistosome immune evasion. Eur J Immunol 33: 2764-2772 [PMID:14515260]

194. Hirai H, Tanaka K, Takano S, Ichimasa M, Nakamura M and Nagata K. (2002) Cutting edge: agonistic effect of indomethacin on a prostaglandin D2 receptor, CRTH2. J Immunol 168: 981-5 [PMID:11801628]

195. Hirai H, Tanaka K, Yoshie O, Ogawa K, Kenmotsu K, Takamori Y, Ichimasa M, Sugamura K, Nakamura M and Takano S et al.. (2001) Prostaglandin D2 selectively induces chemotaxis in T helper type 2 cells, eosinophils, and basophils via seven-transmembrane receptor CRTH2.J Exp Med 193: 255-61 [PMID:11208866]

196. Hirata M, Hayashi Y, Ushikubi F, Yokota Y, Kageyama R, Nakanishi S and Narumiya S. (1991) Cloning and expression of cDNA for a human thromboxane A2 receptor. Nature 349: 617-20 [PMID:1825698]

197. Hirata M, Kakizuka A, Aizawa M, Ushikubi F and Narumiya S. (1994) Molecular characterization of a mouse prostaglandin D receptor and functional expression of the cloned gene. Proc Natl Acad Sci USA 91: 11192-6 [PMID:7972033]

198. Hirata T, Kakizuka A, Ushikubi F, Fuse I, Okuma M and Narumiya S. (1994) Arg60 to Leu mutation of the human thromboxane A2 receptor in a dominantly inherited bleeding disorder. $J$ Clin Invest 94: 1662-7 [PMID:7929844]

199. Hirata T and Narumiya S. (2011) Prostanoid receptors. Chem Rev 111: 6209-30 [PMID:21819041]

200. Hirata T, Ushikubi F, Kakizuka A, Okuma M and Narumiya S. (1996) Two thromboxane A2 receptor isoforms in human platelets. Opposite coupling to adenylyl cyclase with different sensitivity to Arg60 to Leu mutation. J Clin Invest 97: 949-56 [PMID:8613548]

201. Hishikari K, Suzuki J, Ogawa M, Isobe K, Takahashi T, Onishi M, Takayama K and Isobe M. (2009) Pharmacological activation of the prostaglandin E2 receptor EP4 improves cardiac function after myocardial ischaemia/reperfusion injury. Cardiovasc Res 81: 123-32 [PMID:18805784]

202. Hizaki H, Segi E, Sugimoto Y, Hirose M, Saji T, Ushikubi F, Matsuoka T, Noda Y, Tanaka T and Yoshida $\mathrm{N}$ et al.. (1999) Abortive expansion of the cumulus and impaired fertility in mice lacking the prostaglandin E receptor subtype EP(2). Proc Natl Acad Sci USA 96: 10501-6 [PMID:10468638]

203. Hohjoh H, Inazumi T, Tsuchiya S and Sugimoto Y. (2014) Prostanoid receptors and acute inflammation in skin. Biochimie 107 Pt A: 78-81 [PMID:25179301]

204. Honda A, Sugimoto Y, Namba T, Watabe A, Irie A, Negishi M, Narumiya S and Ichikawa A. (1993) Cloning and expression of a cDNA for mouse prostaglandin E receptor EP2 subtype. $J$ Biol Chem 268: 7759-62 [PMID:8385118]

205. Honda T, Matsuoka T, Ueta M, Kabashima K, Miyachi Y and Narumiya S. (2009) Prostaglandin $\mathrm{E}(2)-\mathrm{EP}(3)$ signaling suppresses skin inflammation in murine contact hypersensitivity. J Allergy Clin Immunol 124: 809-18.e2 [PMID:19541354]

206. Honda T, Segi-Nishida E, Miyachi Y and Narumiya S. (2006) Prostacyclin-IP signaling and 
prostaglandin E2-EP2/EP4 signaling both mediate joint inflammation in mouse collagen-induced arthritis. J Exp Med 203: 325-35 [PMID:16446378]

207. Hoshikawa Y, Voelkel NF, Gesell TL, Moore MD, Morris KG, Alger LA, Narumiya S and Geraci MW. (2001) Prostacyclin receptor-dependent modulation of pulmonary vascular remodeling. Am J Respir Crit Care Med 164: 314-8 [PMID:11463607]

208. Hosoi M, Oka T and Hori T. (1997) Prostaglandin E receptor EP3 subtype is involved in thermal hyperalgesia through its actions in the preoptic hypothalamus and the diagonal band of Broca in rats. Pain 71: 303-311 [PMID:9231874]

209. Hristovska AM, Rasmussen LE, Hansen PB, Nielsen SS, Nüsing RM, Narumiya S, Vanhoutte P, Skøtt O and Jensen BL. (2007) Prostaglandin E2 induces vascular relaxation by E-prostanoid 4 receptor-mediated activation of endothelial nitric oxide synthase. Hypertension 50: 525-30 [PMID:17635857]

210. Hung GH, Jones RL, Lam FF, Chan KM, Hidaka H, Suzuki M and Sasaki Y. (2006) Investigation of the pronounced synergism between prostaglandin E2 and other constrictor agents on rat femoral artery. Prostaglandins Leukot Essent Fatty Acids 74: 401-15 [PMID:16737803]

211. Hébert RL, O'Connor T, Neville C, Burns KD, Laneuville O and Peterson LN. (1998) Prostanoid signaling, localization, and expression of IP receptors in rat thick ascending limb cells. $A m J$ Physiol 275: F904-14 [PMID:9843907]

212. Ibrahim NM, Young LG and Fröhlich O. (2001) Epididymal specificity and androgen regulation of rat EP2. Biol Reprod 65: 575-80 [PMID:11466228]

213. Ibrahim S, McCartney A, Markosyan N and Smyth EM. (2013) Heterodimerization with the prostacyclin receptor triggers thromboxane receptor relocation to lipid rafts. Arterioscler Thromb Vasc Biol 33: 60-6 [PMID:23162015]

214. Ichikawa A, Negishi M and Hasegawa H. (1997) Three isoforms of the prostaglandin E receptor EP3 subtype different in agonist-independent constitutive Gi activity and agonist-dependent Gs activity. Adv Exp Med Biol 433: 239-42 [PMID:9561144]

215. Ichikawa A, Sugimoto Y and Tanaka S. (2010) Molecular biology of histidine decarboxylase and prostaglandin receptors. Proc Jpn Acad, Ser B, Phys Biol Sci 86: 848-66 [PMID:20948178]

216. Ikeda M, Kawatani M, Maruyama T and Ishihama H. (2006) Prostaglandin facilitates afferent nerve activity via EP1 receptors during urinary bladder inflammation in rats. Biomed Res 27: 49-54 [PMID:16707842]

217. Ikeda-Matsuo Y, Tanji H, Narumiya S and Sasaki Y. (2011) Inhibition of prostaglandin E2 EP3 receptors improves stroke injury via anti-inflammatory and anti-apoptotic mechanisms. $J$ Neuroimmunol 238: 34-43 [PMID:21803432]

218. Imig JD, Breyer MD and Breyer RM. (2002) Contribution of prostaglandin EP(2) receptors to renal microvascular reactivity in mice. Am J Physiol Renal Physiol 283: F415-22 [PMID:12167591]

219. Inazumi T, Yamada K, Shirata N, Sato H, Taketomi Y, Morita K, Hohjoh H, Tsuchiya S, Oniki K and Watanabe T et al.. (2020) Prostaglandin $E_{2}$-EP4 Axis Promotes Lipolysis and Fibrosis in Adipose Tissue Leading to Ectopic Fat Deposition and Insulin Resistance. Cell Rep 33: 108265 [PMID:33053354]

220. International Multiple Sclerosis Genetics Consortium, Wellcome Trust Case Control Consortium 2, Sawcer S, Hellenthal G, Pirinen M, Spencer CC, Patsopoulos NA, Moutsianas L, Dilthey A and $\mathrm{Su} \mathrm{Z}$ et al.. (2011) Genetic risk and a primary role for cell-mediated immune mechanisms in multiple sclerosis. Nature 476: 214-9 [PMID:21833088]

221. Ishida N, Odani-Kawabata N, Shimazaki A and Hara H. (2006) Prostanoids in the therapy of glaucoma. Cardiovasc Drug Rev 24: 1-10 [PMID:16939629]

222. Ishiguro S, Arii S, Monden K, Adachi Y, Funaki N, Higashitsuji H, Fujita S, Furutani M, Mise M and Kitao T et al.. (1994) Identification of the thromboxane A2 receptor in hepatic sinusoidal endothelial cells and its role in endotoxin-induced liver injury in rats. Hepatology 20: 1281-6 [PMID:7927263]

223. Ishikawa TO, Tamai Y, Rochelle JM, Hirata M, Namba T, Sugimoto Y, Ichikawa A, Narumiya S, Taketo MM and Seldin MF. (1996) Mapping of the genes encoding mouse prostaglandin D, E, and $\mathrm{F}$ and prostacyclin receptors. Genomics 32: 285-8 [PMID:8833158]

224. Israel DD and Regan JW. (2009) EP(3) prostanoid receptor isoforms utilize distinct mechanisms to regulate ERK 1/2 activation. Biochim Biophys Acta 1791: 238-45 [PMID:19416642]

225. Ito S, Negishi M, Sugama K, Okuda-Ashitaka E and Hayaishi O. (1991) Signal transduction coupled to prostaglandin D2. Adv Prostaglandin Thromboxane Leukot Res 21A: 371-4 [PMID:1705384]

226. Ito S, Sakamoto K, Mochizuki-Oda N, Ezashi T, Miwa K, Okuda-Ashitaka E, Shevchenko VI, Kiso Y and Hayaishi O. (1994) Prostaglandin F2 alpha receptor is coupled to Gq in cDNA-transfected Chinese hamster ovary cells. Biochem Biophys Res Commun 200: 756-62 [PMID:8179609]

227. Itoh T, Ueno H and Kuriyama H. (1985) Calcium-induced calcium release mechanism in vascular smooth muscles--assessments based on contractions evoked in intact and saponin-treated skinned muscles. Experientia 41: 989-96 [PMID:2990997] 
228. Iyú D, Glenn JR, White AE, Johnson AJ, Fox SC and Heptinstall S. (2010) The role of prostanoid receptors in mediating the effects of PGE(2) on human platelet function. Platelets 21: 329-42 [PMID:20433310]

229. Jaffar Z, Ferrini ME, Buford MC, Fitzgerald GA and Roberts K. (2007) Prostaglandin I2-IP signaling blocks allergic pulmonary inflammation by preventing recruitment of CD4+ Th2 cells into the airways in a mouse model of asthma. J Immunol 179: 6193-203 [PMID:17947695]

230. Jaffar Z, Ferrini ME, Shaw PK, FitzGerald GA and Roberts K. (2011) Prostaglandin I2promotes the development of IL-17-producing $\gamma \delta$ T cells that associate with the epithelium during allergic lung inflammation. J Immunol 187: 5380-91 [PMID:21976777]

231. Jain S, Chakraborty G, Raja R, Kale S and Kundu GC. (2008) Prostaglandin E2 regulates tumor angiogenesis in prostate cancer. Cancer Res 68: 7750-9 [PMID:18829529]

232. Jandl K, Stacher E, Bálint Z, Sturm EM, Maric J, Peinhaupt M, Luschnig P, Aringer I, Fauland A and Konya V et al.. (2016) Activated prostaglandin D2 receptors on macrophages enhance neutrophil recruitment into the lung. J Allergy Clin Immunol 137: 833-43 [PMID:26792210]

233. Jenkins DW, Feniuk W and Humphrey PP. (2001) Characterization of the prostanoid receptor types involved in mediating calcitonin gene-related peptide release from cultured rat trigeminal neurones. Br J Pharmacol 134: 1296-302 [PMID:11704650]

234. Jensen BL, Mann B, Skøtt O and Kurtz A. (1999) Differential regulation of renal prostaglandin receptor mRNAs by dietary salt intake in the rat. Kidney Int 56: 528-37 [PMID:10432392]

235. Jewell ML, Breyer RM and Currie KP. (2011) Regulation of calcium channels and exocytosis in mouse adrenal chromaffin cells by prostaglandin EP3 receptors. Mol Pharmacol 79: 987-96 [PMID:21383044]

236. Jiang C, Amaradhi R, Ganesh T and Dingledine R. (2020) An Agonist Dependent Allosteric Antagonist of Prostaglandin EP2 Receptors. ACS Chem Neurosci 11: 1436-1446 [PMID:32324375]

237. Jiang J and Dingledine R. (2013) Role of prostaglandin receptor EP2 in the regulations of cancer cell proliferation, invasion, and inflammation. J Pharmacol Exp Ther 344: 360-7 [PMID:23192657]

238. Jiang J, Ganesh T, Du Y, Quan Y, Serrano G, Qui M, Speigel I, Rojas A, Lelutiu N and Dingledine R. (2012) Small molecule antagonist reveals seizure-induced mediation of neuronal injury by prostaglandin E2 receptor subtype EP2. Proc Natl Acad Sci USA 109: 3149-54 [PMID:22323596]

239. Jiang J, Ganesh T, Du Y, Thepchatri P, Rojas A, Lewis I, Kurtkaya S, Li L, Qui M and Serrano G et al.. (2010) Neuroprotection by selective allosteric potentiators of the EP2 prostaglandin receptor. Proc Natl Acad Sci USA 107: 2307-12 [PMID:20080612]

240. Jiang J, Van TM, Ganesh T and Dingledine R. (2018) Discovery of 2-Piperidinyl Phenyl Benzamides and Trisubstituted Pyrimidines as Positive Allosteric Modulators of the Prostaglandin Receptor EP2. ACS Chem Neurosci 9: 699-707 [PMID:29292987]

241. Jin J, Mao GF and Ashby B. (1997) Constitutive activity of human prostaglandin E receptor EP3 isoforms. Br J Pharmacol 121: 317-23 [PMID:9154343]

242. Johansson T, Narumiya S and Zeilhofer HU. (2011) Contribution of peripheral versus central EP1 prostaglandin receptors to inflammatory pain. Neurosci Lett 495: 98-101 [PMID:21440042]

243. Johnston SL, Freezer NJ, Ritter W, O'Toole S and Howarth PH. (1995) Prostaglandin D2-induced bronchoconstriction is mediated only in part by the thromboxane prostanoid receptor. Eur Respir J 8: 411-415 [PMID:7789486]

244. Johnston SL, Smith S, Harrison J, Ritter W and Howarth PH. (1993) The effect of BAY u 3405, a thromboxane receptor antagonist, on prostaglandin D2-induced nasal blockage. J Allergy Clin Immunol 91: 903-9 [PMID:8473679]

245. Jones CL, Li T and Cowley EA. (2012) The prostaglandin $\mathrm{E}_{2}$ type 4 receptor participates in the response to acute oxidant stress in airway epithelial cells. J Pharmacol Exp Ther 341: 552-63 [PMID:22362924]

246. Jones RL. (1978) Definition of prostaglandin-sensitive arterial constrictor systems. Acta Biol Med Ger 37: 837-44 [PMID:742299]

247. Jones RL, Giembycz MA and Woodward DF. (2009) Prostanoid receptor antagonists: development strategies and therapeutic applications. Br J Pharmacol 158: 104-45 [PMID:19624532]

248. Jones RL and Marr CG. (1977) Actions of 16-aryloxy analogues of prostaglandin F2alpha on preparations responsive to prostaglandin endoperoxides. Br J Pharmacol 61: 694-6 [PMID:597671]

249. Jones RL, Peesapati V and Wilson NH. (1982) Antagonism of the thromboxane-sensitive contractile systems of the rabbit aorta, dog saphenous vein and guinea-pig trachea. $\mathrm{Br} \mathrm{J}$ Pharmacol 76: 423-38 [PMID:6286023]

250. Jones RL, Qian YM, Chan KM and Yim AP. (1998) Characterization of a prostanoid EP3-receptor in guinea-pig aorta: partial agonist action of the non-prostanoid ONO-AP-324. Br J Pharmacol 125: 1288-96 [PMID:9863659] 
251. Jones RL, Qian YM, Wise H, Wong HN, Lam WL, Chan HW, Yim AP and Ho JK. (1997) Relaxant actions of nonprostanoid prostacyclin mimetics on human pulmonary artery. J Cardiovasc Pharmacol 29: 525-35 [PMID:9156364]

252. Jones RL, Wan Ahmad WA, Woodward DF and Wang J. (2013) Nature of the slow relaxation of smooth muscle induced by a EP2 receptor agonist with a non-prostanoid structure.

Prostaglandins Leukot Essent Fatty Acids 88: 321-30 [PMID:23419768]

253. Jones RL, Wilson NH and Lawrence RA. (1989) EP 171: a high affinity thromboxane A2-mimetic, the actions of which are slowly reversed by receptor blockade. Br J Pharmacol 96: 875-87 [PMID:2743082]

254. Jones RL, Wilson NH, Marr CG, Muir G and Armstrong RA. (1993) Diphenylmethylazine prostanoids with prostacyclin-like actions on human platelets. J Lipid Mediat 6: 405-10 [PMID:8357998]

255. Jones RL, Wise H, Clark R, Whiting RL and Bley KR. (2006) Investigation of the prostacyclin (IP) receptor antagonist RO1138452 on isolated blood vessel and platelet preparations. $\mathrm{BrJ}$ Pharmacol 149: 110-20 [PMID:16880763]

256. Jones RL, Woodward DF, Wang JW and Clark RL. (2011) Roles of affinity and lipophilicity in the slow kinetics of prostanoid receptor antagonists on isolated smooth muscle preparations. $\mathrm{BrJ}$ Pharmacol 162: 863-79 [PMID:20973775]

257. Jugus MJ, Jaworski JP, Patra PB, Jin J, Morrow DM, Laping NJ, Edwards RM and Thorneloe KS. (2009) Dual modulation of urinary bladder activity and urine flow by prostanoid EP3 receptors in the conscious rat. Br J Pharmacol 158: 372-81 [PMID:19486006]

258. Jumblatt MM, Neltner AA, Coca-Prados M and Paterson CA. (1994) EP2-receptor stimulated cyclic AMP synthesis in cultured human non-pigmented ciliary epithelium. Exp Eye Res 58: 5636 [PMID:7925693]

259. Juteau H, Gareau Y, Labelle M, Sturino CF, Sawyer N, Tremblay N, Lamontagne S, Carrière MC, Denis D and Metters KM. (2001) Structure-activity relationship of cinnamic acylsulfonamide analogues on the human EP3 prostanoid receptor. Bioorg Med Chem 9: 1977-84 [PMID:11504634]

260. Kabashima K, Murata T, Tanaka H, Matsuoka T, Sakata D, Yoshida N, Katagiri K, Kinashi T, Tanaka T and Miyasaka M et al.. (2003) Thromboxane A2 modulates interaction of dendritic cells and T cells and regulates acquired immunity. Nat Immunol 4: 694-701 [PMID:12778172]

261. Kabashima K, Saji T, Murata T, Nagamachi M, Matsuoka T, Segi E, Tsuboi K, Sugimoto Y, Kobayashi T and Miyachi Y et al.. (2002) The prostaglandin receptor EP4 suppresses colitis, mucosal damage and CD4 cell activation in the gut. J Clin Invest 109: 883-93 [PMID:11927615]

262. Kabashima K, Sakata D, Nagamachi M, Miyachi Y, Inaba K and Narumiya S. (2003) Prostaglandin E2-EP4 signaling initiates skin immune responses by promoting migration and maturation of Langerhans cells. Nat Med 9: 744-9 [PMID:12740571]

263. Kajikawa N, Nogimori K, Murata T, Nishio S and Uchiyama S. (1989) Specific binding of the new stable epoprostenol analogue beraprost sodium to prostacyclin receptors on human and rat platelets. Arzneimittelforschung 39: 495-9 [PMID:2665758]

264. Kambe T, Maruyama T, Nakano M, Nakai Y, Yoshida T, Matsunaga N, Oida H, Konaka A, Maruyama T and Nakai H et al.. (2012) Discovery of a novel EP2/EP4 dual agonist with high subtype-selectivity. Bioorg Med Chem Lett 22: 396-401 [PMID:22119471]

265. Kamiyama M, Pozzi A, Yang L, DeBusk LM, Breyer RM and Lin PC. (2006) EP2, a receptor for PGE2, regulates tumor angiogenesis through direct effects on endothelial cell motility and survival. Oncogene 25: 7019-28 [PMID:16732324]

266. Kanamori Y, Niwa M, Kohno K, Al-Essa LY, Matsuno H, Kozawa O and Uematsu T. (1997) Migration of neutrophils from blood to tissue: alteration of modulatory effects of prostanoid on superoxide generation in rabbits and humans. Life Sci 60: 1407-17 [PMID:9096262]

267. Kaneko Y, Nakayama T, Saito K, Morita A, Sato I, Maruyama A, Soma M, Takahashi T and Sato N. (2006) Relationship between the thromboxane A2 receptor gene and susceptibility to cerebral infarction. Hypertens Res 29: 665-71 [PMID:17249521]

268. Katagiri H, Ito Y, Ito S, Murata T, Yukihiko S, Narumiya S, Watanabe M and Majima M. (2008) TNF-alpha induces thromboxane receptor signaling-dependent microcirculatory dysfunction in mouse liver. Shock 30: 463-7 [PMID:18800000]

269. Kataoka H, Sakanaka M, Semma M, Yamamoto T, Hirota S, Tanaka S and Ichikawa A. (2008) PGE2-receptor subtype EP4-dependent adherence of mastocytoma P-815 cells to matrix components in subcutaneous tissues overlaying inside surface of air pouch cavity in CDF1 mouse. Inflamm Res 57: 362-6 [PMID:18787774]

270. Kato S, Aihara E, Yoshii K and Takeuchi K. (2005) Dual action of prostaglandin E2 on gastric acid secretion through different EP-receptor subtypes in the rat. Am J Physiol Gastrointest Liver Physiol 289: G64-9 [PMID:15961884]

271. Katoh H, Watabe A, Sugimoto Y, Ichikawa A and Negishi M. (1995) Characterization of the signal transduction of prostaglandin E receptor EP1 subtype in cDNA-transfected Chinese hamster ovary cells. Biochim Biophys Acta 1244: 41-8 [PMID:7766667] 
272. Katsuyama M, Nishigaki N, Sugimoto Y, Morimoto K, Negishi M, Narumiya S and Ichikawa A. (1995) The mouse prostaglandin E receptor EP2 subtype: cloning, expression, and northern blot analysis. FEBS Lett 372: 151-6 [PMID:7556658]

273. Kattelman EJ, Venton DL and Le Breton GC. (1986) Characterization of U46619 binding in unactivated, intact human platelets and determination of binding site affinities of four TXA2/PGH2 receptor antagonists (13-APA, BM 13.177, ONO 3708 and SQ 29,548). Thromb Res 41: 471-81 [PMID:3008368]

274. Kawabe J, Yuhki K, Okada M, Kanno T, Yamauchi A, Tashiro N, Sasaki T, Okumura S, Nakagawa $\mathrm{N}$ and Aburakawa Y et al.. (2010) Prostaglandin I2 promotes recruitment of endothelial progenitor cells and limits vascular remodeling. Arterioscler Thromb Vasc Biol 30: 464-70 [PMID:20007911]

275. Kawahara H, Sakamoto A, Takeda S, Onodera H, Imaki J and Ogawa R. (2001) A prostaglandin E2 receptor subtype EP1 receptor antagonist (ONO-8711) reduces hyperalgesia, allodynia, and c-fos gene expression in rats with chronic nerve constriction. Anesth Analg 93: 1012-7 [PMID:11574375]

276. Kawamori T, Kitamura T, Watanabe K, Uchiya N, Maruyama T, Narumiya S, Sugimura T and Wakabayashi K. (2005) Prostaglandin E receptor subtype EP(1) deficiency inhibits colon cancer development. Carcinogenesis 26: 353-7 [PMID:15564292]

277. Kawamura T, Yamauchi T, Koyama M, Maruyama T, Akira T and Nakamura N. (1997) Expression of prostaglandin EP2 receptor mRNA in the rat spinal cord. Life Sci 61: 2111-6 [PMID:9395252]

278. Kawano T, Anrather J, Zhou P, Park L, Wang G, Frys KA, Kunz A, Cho S, Orio M and Iadecola C. (2006) Prostaglandin E2 EP1 receptors: downstream effectors of COX-2 neurotoxicity. Nat Med 12: 225-9 [PMID:16432513]

279. Kay LJ, Gilbert M, Pullen N, Skerratt S, Farrington J, Seward EP and Peachell PT. (2013) Characterization of the EP receptor subtype that mediates the inhibitory effects of prostaglandin E2 on IgE-dependent secretion from human lung mast cells. Clin Exp Allergy 43: 741-51 [PMID:23786281]

280. Keery RJ and Lumley P. (1988) AH6809, a prostaglandin DP-receptor blocking drug on human platelets. Br J Pharmacol 94: 745-54 [PMID:2460179]

281. Kelly CR, Williams GW and Sharif NA. (2003) Real-time intracellular Ca2+ mobilization by travoprost acid, bimatoprost, unoprostone, and other analogs via endogenous mouse, rat, and cloned human FP prostaglandin receptors. J Pharmacol Exp Ther 304: 238-45 [PMID:12490597]

282. Kennedy CR, Zhang Y, Brandon S, Guan Y, Coffee K, Funk CD, Magnuson MA, Oates JA, Breyer MD and Breyer RM. (1999) Salt-sensitive hypertension and reduced fertility in mice lacking the prostaglandin EP2 receptor. Nat Med 5: 217-20 [PMID:9930871]

283. Kimball FA, Lauderdale JW, Nelson NA and Jackson RW. (1976) Comparison of luteolytic effectiveness of several prostaglandin analogs in heifers and relative binding affinity for bovine luteal prostaglandin binding sites. Prostaglandins 12: 985-995 [PMID:188076]

284. Kimura T, Ogita K, Kusui C, Ohashi K, Azuma C and Murata Y. (1999) What knockout mice can tell us about parturition. Rev Reprod 4: 73-80 [PMID:10357094]

285. Kinsella BT. (2001) Thromboxane A2 signalling in humans: a 'Tail' of two receptors. Biochem Soc Trans 29: 641-54 [PMID:11709048]

286. Kinsella BT, O'Mahony DJ and Fitzgerald GA. (1997) The human thromboxane A2 receptor alpha isoform (TP alpha) functionally couples to the G proteins Gq and G11 in vivo and is activated by the isoprostane 8-epi prostaglandin F2 alpha. J Pharmacol Exp Ther 281: 957-64 [PMID:9152406]

287. Kinsella BT and Reid H. (2016) Thromboxane receptor antagonists Patent number: WO2016203314A1.

288. Kirihara T, Taniguchi T, Yamamura K, Iwamura R, Yoneda K, Odani-Kawabata N, Shimazaki A, Matsugi T, Shams N and Zhang JZ. (2018) Pharmacologic Characterization of Omidenepag Isopropyl, a Novel Selective EP2 Receptor Agonist, as an Ocular Hypotensive Agent. Invest Ophthalmol Vis Sci 59: 145-153 [PMID:29332128]

289. Kiriyama M, Ushikubi F, Kobayashi T, Hirata M, Sugimoto Y and Narumiya S. (1997) Ligand binding specificities of the eight types and subtypes of the mouse prostanoid receptors expressed in Chinese hamster ovary cells. Br J Pharmacol 122: 217-24 [PMID:9313928]

290. Kishino J, Hanasaki K, Nagasaki T and Arita H. (1991) Kinetic studies on stereospecific recognition by the thromboxane A2/prostaglandin $\mathrm{H} 2$ receptor of the antagonist, S-145. $\mathrm{Br} \mathrm{J}$ Pharmacol 103: 1883-8 [PMID:1833018]

291. Kitanaka J, Hasimoto H, Sugimoto Y, Negishi M, Aino H, Gotoh M, Ichikawa A and Baba A. (1994) Cloning and expression of a cDNA for rat prostaglandin F2 alpha receptor. Prostaglandins 48: 31-41 [PMID:7972878]

292. Kitaoka S, Furuyashiki T, Nishi A, Shuto T, Koyasu S, Matsuoka T, Miyasaka M, Greengard P and Narumiya S. (2007) Prostaglandin E2 acts on EP1 receptor and amplifies both dopamine D1 and D2 receptor signaling in the striatum. J Neurosci 27: 12900-7 [PMID:18032663] 
293. Kobayashi K, Murata T, Hori M and Ozaki H. (2011) Prostaglandin E2-prostanoid EP3 signal induces vascular contraction via nPKC and ROCK activation in rat mesenteric artery. Eur J Pharmacol 660: 375-80 [PMID:21463619]

294. Kobayashi K, Tsubosaka Y, Hori M, Narumiya S, Ozaki H and Murata T. (2013) Prostaglandin D2-DP signaling promotes endothelial barrier function via the cAMP/PKA/Tiam1/Rac1 pathway. Arterioscler Thromb Vasc Biol 33: 565-71 [PMID:23307871]

295. Kobayashi T and Narumiya S. (2002) Function of prostanoid receptors: studies on knockout mice. Prostaglandins Other Lipid Mediat 68-69: 557-73 [PMID:12432943]

296. Kobayashi T, Tahara Y, Matsumoto M, Iguchi M, Sano H, Murayama T, Arai H, Oida H, YurugiKobayashi T and Yamashita JK et al.. (2004) Roles of thromboxane A(2) and prostacyclin in the development of atherosclerosis in apoE-deficient mice. J Clin Invest 114: 784-94 [PMID:15372102]

297. Kolodsick JE, Peters-Golden M, Larios J, Toews GB, Thannickal VJ and Moore BB. (2003) Prostaglandin E2 inhibits fibroblast to myofibroblast transition via E. prostanoid receptor 2 signaling and cyclic adenosine monophosphate elevation. Am J Respir Cell Mol Biol 29: 537-44 [PMID:12738687]

298. Komuro M, Kamiyama M, Furuya Y, Takihana Y, Araki I and Takeda M. (2006) Gene and protein expression profiles of prostaglandin E2 receptor subtypes in the human corpus cavernosum. Int J Impot Res 18: 275-81 [PMID:16239896]

299. Konya V, Philipose S, Bálint Z, Olschewski A, Marsche G, Sturm EM, Schicho R, Peskar BA, Schuligoi R and Heinemann A. (2011) Interaction of eosinophils with endothelial cells is modulated by prostaglandin EP4 receptors. Eur J Immunol 41: 2379-89 [PMID:21681739]

300. Kosuge Y, Miyagishi H, Shinomiya T, Nishiyama K, Suzuki S, Osada N, Ishige K, Okubo M, Kawaguchi M and Ito Y. (2015) Characterization of Motor Neuron Prostaglandin E2 EP3 Receptor Isoform in a Mouse Model of Amyotrophic Lateral Sclerosis. Biol Pharm Bull 38: 19648 [PMID:26632188]

301. Kotani M, Tanaka I, Ogawa Y, Usui T, Mori K, Ichikawa A, Narumiya S, Yoshimi T and Nakao K. (1995) Molecular cloning and expression of multiple isoforms of human prostaglandin $\mathrm{E}$ receptor EP3 subtype generated by alternative messenger RNA splicing: multiple second messenger systems and tissue-specific distributions. Mol Pharmacol 48: 869-79 [PMID:7476918]

302. Kotani M, Tanaka I, Ogawa Y, Usui T, Tamura N, Mori K, Narumiya S, Yoshimi T and Nakao K. (1997) Structural organization of the human prostaglandin EP3 receptor subtype gene (PTGER3). Genomics 40: 425-34 [PMID:9073510]

303. Kotani T, Kobata A, Nakamura E, Amagase K and Takeuchi K. (2006) Roles of cyclooxygenase-2 and prostacyclin/IP receptors in mucosal defense against ischemia/reperfusion injury in mouse stomach. J Pharmacol Exp Ther 316: 547-55 [PMID:16236816]

304. Kotelevets L, Foudi N, Louedec L, Couvelard A, Chastre E and Norel X. (2007) A new mRNA splice variant coding for the human EP3-I receptor isoform. Prostaglandins Leukot Essent Fatty Acids 77: 195-201 [PMID:18023986]

305. Krause A, Zisowsky J, Strasser DS, Gehin M, Sidharta PN, Groenen PMA and Dingemanse J. (2016) Pharmacokinetic/Pharmacodynamic Modelling of Receptor Internalization with CRTH2 Antagonists to Optimize Dose Selection. Clin Pharmacokinet 55: 813-821 [PMID:26692193]

306. Krauss AH, Impagnatiello F, Toris CB, Gale DC, Prasanna G, Borghi V, Chiroli V, Chong WK, Carreiro ST and Ongini E. (2011) Ocular hypotensive activity of BOL-303259-X, a nitric oxide donating prostaglandin F2 $\alpha$ agonist, in preclinical models. Exp Eye Res 93: 250-5 [PMID:21396362]

307. Krauss AH, Woodward DF, Gibson LL, Protzman CE, Williams LS, Burk RM, Gac TS, Roof MB, Abbas F and Marshall K et al.. (1996) Evidence for human thromboxane receptor heterogeneity using a novel series of 9,11-cyclic carbonate derivatives of prostaglandin F2 alpha. $\mathrm{BrJ}$ Pharmacol 117: 1171-80 [PMID:8882612]

308. Kubo S, Takahashi HK, Takei M, Iwagaki H, Yoshino T, Tanaka N, Mori S and Nishibori M. (2004) E-prostanoid (EP)2/EP4 receptor-dependent maturation of human monocyte-derived dendritic cells and induction of helper T2 polarization. J Pharmacol Exp Ther 309: 1213-20 [PMID:14872092]

309. Kunapuli SP, Fen Mao G, Bastepe M, Liu-Chen LY, Li S, Cheung PP, DeRiel JK and Ashby B. (1994) Cloning and expression of a prostaglandin E receptor EP3 subtype from human erythroleukaemia cells. Biochem J 298 ( Pt 2): 263-7 [PMID:8135729]

310. Kunikata T, Araki H, Takeeda M, Kato S and Takeuchi K. (2001) Prostaglandin E prevents indomethacin-induced gastric and intestinal damage through different EP receptor subtypes. $J$ Physiol Paris 95: 157-63 [PMID:11595431]

311. Kunikata T, Tanaka A, Miyazawa T, Kato S and Takeuchi K. (2002) 16,16-Dimethyl prostaglandin E2 inhibits indomethacin-induced small intestinal lesions through EP3 and EP4 receptors. Dig Dis Sci 47: 894-904 [PMID:11991626]

312. Kunikata T, Yamane H, Segi E, Matsuoka T, Sugimoto Y, Tanaka S, Tanaka H, Nagai H, Ichikawa A and Narumiya S. (2005) Suppression of allergic inflammation by the prostaglandin E receptor 
subtype EP3. Nat Immunol 6: 524-31 [PMID:15806106]

313. Kuwano K, Hashino A, Asaki T, Hamamoto T, Yamada T, Okubo K and Kuwabara K. (2007) 2-[4[(5,6-diphenylpyrazin-2-yl)(isopropyl)amino]butoxy]-N-(methylsulfonyl)acetamide (NS-304), an orally available and long-acting prostacyclin receptor agonist prodrug. J Pharmacol Exp Ther 322: 1181-8 [PMID:17545310]

314. Kvirkvelia N, McMenamin M, Chaudhary K, Bartoli M and Madaio MP. (2013) Prostaglandin E2 promotes cellular recovery from established nephrotoxic serum nephritis in mice, prosurvival, and regenerative effects on glomerular cells. Am J Physiol Renal Physiol 304: F463-70 [PMID:23283994]

315. Lake S, Gullberg H, Wahlqvist J, Sjögren AM, Kinhult A, Lind P, Hellström-Lindahl E and Stjernschantz J. (1994) Cloning of the rat and human prostaglandin F2 alpha receptors and the expression of the rat prostaglandin F2 alpha receptor. FEBS Lett 355: 317-25 [PMID:7988697]

316. Lawrence RA and Jones RL. (1992) Investigation of the prostaglandin E (EP-) receptor subtype mediating relaxation of the rabbit jugular vein. Br J Pharmacol 105: 817-24 [PMID:1324050]

317. Lawrence RA, Jones RL and Wilson NH. (1992) Characterization of receptors involved in the direct and indirect actions of prostaglandins E and I on the guinea-pig ileum. Br J Pharmacol 105: 271-8 [PMID:1559125]

318. Lazarus M, Yoshida K, Coppari R, Bass CE, Mochizuki T, Lowell BB and Saper CB. (2007) EP3 prostaglandin receptors in the median preoptic nucleus are critical for fever responses. Nat Neurosci 10: 1131-3 [PMID:17676060]

319. Leduc M, Breton B, Galés C, Le Gouill C, Bouvier M, Chemtob S and Heveker N. (2009) Functional selectivity of natural and synthetic prostaglandin EP4 receptor ligands. J Pharmacol Exp Ther 331: 297-307 [PMID:19584306]

320. Leduc M, Hou X, Hamel D, Sanchez M, Quiniou C, Honoré JC, Roy O, Madaan A, Lubell W and Varma DR et al.. (2013) Restoration of renal function by a novel prostaglandin EP4 receptorderived peptide in models of acute renal failure. Am J Physiol Regul Integr Comp Physiol 304: R10-22 [PMID:23152113]

321. Lee J, Aoki T, Thumkeo D, Siriwach R, Yao C and Narumiya S. (2019) T cell-intrinsic prostaglandin $\mathrm{E}_{2}$-EP2/EP4 signaling is critical in pathogenic $\mathrm{T}_{\mathrm{H}} 17$ cell-driven inflammation. $J$ Allergy Clin Immunol 143: 631-643 [PMID:29935220]

322. Lee RH, Goodwin TM, Yang W, Li A, Wilson ML, Mullin PM and Felix JC. (2009) Quantitative detection of EP3-II, III and VI messenger RNA in gravid and non-gravid human myometrium using real-time RT-PCR. J Matern Fetal Neonatal Med 22: 59-64 [PMID:19165680]

323. Leonhardt A, Glaser A, Wegmann M, Hackenberg R and Nüsing RM. (2003) Expression of prostanoid receptors in human lower segment pregnant myometrium. Prostaglandins Leukot Essent Fatty Acids 69: 307-13 [PMID:14580364]

324. Lesault PF, Boyer L, Pelle G, Covali-Noroc A, Rideau D, Akakpo S, Teiger E, Dubois-Randé JL and Adnot S. (2011) Daily administration of the TP receptor antagonist terutroban improved endothelial function in high-cardiovascular-risk patients with atherosclerosis. $\mathrm{Br} \mathrm{J} \mathrm{Clin}$ Pharmacol 71: 844-51 [PMID:21564160]

325. Li M, Healy DR, Li Y, Simmons HA, Crawford DT, Ke HZ, Pan LC, Brown TA and Thompson DD. (2005) Osteopenia and impaired fracture healing in aged EP4 receptor knockout mice. Bone 37: 46-54 [PMID:15869929]

326. Li M, Ke HZ, Qi H, Healy DR, Li Y, Crawford DT, Paralkar VM, Owen TA, Cameron KO and Lefker BA et al.. (2003) A novel, non-prostanoid EP2 receptor-selective prostaglandin E2 agonist stimulates local bone formation and enhances fracture healing. J Bone Miner Res 18: 2033-42 [PMID:14606517]

327. Li X, Okada Y, Pilbeam CC, Lorenzo JA, Kennedy CR, Breyer RM and Raisz LG. (2000) Knockout of the murine prostaglandin EP2 receptor impairs osteoclastogenesis in vitro. Endocrinology 141: 2054-61 [PMID:10830290]

328. Li X and Tai HH. (2013) Activation of thromboxane A2 receptor (TP) increases the expression of monocyte chemoattractant protein -1 (MCP-1)/chemokine (C-C motif) ligand 2 (CCL2) and recruits macrophages to promote invasion of lung cancer cells. PLOS ONE 8: e54073 [PMID:23349788]

329. Li X, Tomita M, Pilbeam CC, Breyer RM and Raisz LG. (2002) Prostaglandin receptor EP2 mediates PGE2 stimulated hypercalcemia in mice in vivo. Prostaglandins Other Lipid Mediat 67: 173-80 [PMID:12013525]

330. Liang X, Lin L, Woodling NS, Wang Q, Anacker C, Pan T, Merchant M and Andreasson K. (2011) Signaling via the prostaglandin $\mathrm{E}_{2}$ receptor EP4 exerts neuronal and vascular protection in a mouse model of cerebral ischemia. J Clin Invest 121: 4362-71 [PMID:21965326]

331. Liang X, Wang Q, Hand T, Wu L, Breyer RM, Montine TJ and Andreasson K. (2005) Deletion of the prostaglandin E2 EP2 receptor reduces oxidative damage and amyloid burden in a model of Alzheimer's disease. J Neurosci 25: 10180-7 [PMID:16267225]

332. Libioulle C, Louis E, Hansoul S, Sandor C, Farnir F, Franchimont D, Vermeire S, Dewit O, de Vos $\mathrm{M}$ and Dixon A et al.. (2007) Novel Crohn disease locus identified by genome-wide 
association maps to a gene desert on 5p13.1 and modulates expression of PTGER4. PLoS Genet 3: e58 [PMID:17447842]

333. Liljebris C, Selén G, Resul B, Stjernschantz J and Hacksell U. (1995) Derivatives of 17-phenyl18,19,20-trinorprostaglandin F2 alpha isopropyl ester: potential antiglaucoma agents. J Med Chem 38: 289-304 [PMID:7830272]

334. Liu CC, Hu S, Chen G, Georgiou J, Arns S, Kumar NS, Young RN and Grynpas MD. (2015) Novel EP4 receptor agonist-bisphosphonate conjugate drug $(\mathrm{C} 1)$ promotes bone formation and improves vertebral mechanical properties in the ovariectomized rat model of postmenopausal bone loss. J Bone Miner Res 30: 670-80 [PMID:25284325]

335. Liu D, Wu L, Breyer R, Mattson MP and Andreasson K. (2005) Neuroprotection by the PGE2 EP2 receptor in permanent focal cerebral ischemia. Ann Neurol 57: 758-61 [PMID:15852374]

336. Liu J, Li AR, Wang Y, Johnson MG, Su Y, Shen W, Wang X, Lively S, Brown M and Lai S et al.. (2011) Discovery of AMG 853, a CRTH2 and DP Dual Antagonist. ACS Med Chem Lett 2: 326-30 [PMID:24900313]

337. Longrois D, Gomez I, Foudi N, Topal G, Dhaouadi M, Kotelevets L, Chastre E and Norel X. (2012) Prostaglandin $E_{2}$ induced contraction of human intercostal arteries is mediated by the $\mathrm{EP}_{3}$ receptor. Eur J Pharmacol 681: 55-9 [PMID:22342278]

338. Luker T, Bonnert R, Brough S, Cook AR, Dickinson MR, Dougall I, Logan C, Mohammed RT, Paine S and Sanganee HJ et al.. (2011) Substituted indole-1-acetic acids as potent and selective CRTh2 antagonists-discovery of AZD1981. Bioorg Med Chem Lett 21: 6288-92 [PMID:21944852]

339. Lumley P, White BP and Humphrey PP. (1989) GR32191, a highly potent and specific thromboxane A2 receptor blocking drug on platelets and vascular and airways smooth muscle in vitro. Br J Pharmacol 97: 783-94 [PMID:2527074]

340. Lundblad C, Grände PO and Bentzer P. (2008) Increased cortical cell loss and prolonged hemodynamic depression after traumatic brain injury in mice lacking the IP receptor for prostacyclin. J Cereb Blood Flow Metab 28: 367-76 [PMID:17713464]

341. Luschnig-Schratl P, Sturm EM, Konya V, Philipose S, Marsche G, Fröhlich E, Samberger C, Lang-Loidolt D, Gattenlöhner S and Lippe IT et al.. (2011) EP4 receptor stimulation downregulates human eosinophil function. Cell Mol Life Sci 68: 3573-87 [PMID:21365278]

342. Ly TW and Bacon KB. (2005) Small-molecule CRTH2 antagonists for the treatment of allergic inflammation: an overview. Expert Opin Investig Drugs 14: 769-73 [PMID:16022566]

343. Ma H, Hara A, Xiao CY, Okada Y, Takahata O, Nakaya K, Sugimoto Y, Ichikawa A, Narumiya S and Ushikubi F. (2001) Increased bleeding tendency and decreased susceptibility to thromboembolism in mice lacking the prostaglandin E receptor subtype EP(3). Circulation 104: 1176-80 [PMID:11535576]

344. Machwate M, Harada S, Leu CT, Seedor G, Labelle M, Gallant M, Hutchins S, Lachance N, Sawyer N and Slipetz D et al.. (2001) Prostaglandin receptor EP(4) mediates the bone anabolic effects of PGE(2). Mol Pharmacol 60: 36-41 [PMID:11408598]

345. Maher SA, Birrell MA and Belvisi MG. (2009) Prostaglandin E2 mediates cough via the EP3 receptor: implications for future disease therapy. Am J Respir Crit Care Med 180: 923-8 [PMID:19729667]

346. Mais DE, DeHoll D, Sightler H and Halushka PV. (1988) Different pharmacologic activities for 13-azapinane thromboxane A2 analogs in platelets and blood vessels. Eur J Pharmacol 148: 30915 [PMID:2968271]

347. Malinowska B, Godlewski G, Buczko W and Schlicker E. (1994) EP3 receptor-mediated inhibition of the neurogenic vasopressor response in pithed rats. Eur J Pharmacol 259: 315-19 [PMID:7982460]

348. Maruyama T, Asada M, Shiraishi T, Ishida A, Egashira H, Yoshida H, Maruyama T, Ohuchida S, Nakai H and Kondo K et al.. (2001) Design and synthesis of a highly selective EP4-receptor agonist. Part 1: 3,7-dithiaPG derivatives with high selectivity. Bioorg Med Chem Lett 11: 202931 [PMID:11454473]

349. Maruyama T, Okada H and Konemura T. (2015) Therapeutic agent for urinary excretion disorder Patent number: US9181187B2.

350. Maseda D, Banerjee A, Johnson EM, Washington MK, Kim H, Lau KS and Crofford LJ. (2018) mPGES-1-Mediated Production of $\mathrm{PGE}_{2}$ and EP4 Receptor Sensing Regulate T Cell Colonic Inflammation. Front Immunol 9: 2954 [PMID:30619314]

351. Masuda A, Mais DE, Oatis Jr JE and Halushka PV. (1991) Platelet and vascular thromboxane A2/prostaglandin H2 receptors. Evidence for different subclasses in the rat. Biochem Pharmacol 42: 537-44 [PMID:1830482]

352. Masuko K, Murata M, Yudoh K, Shimizu H, Beppu M, Nakamura H and Kato T. (2010) Prostaglandin E2 regulates the expression of connective tissue growth factor (CTGF/CCN2) in human osteoarthritic chondrocytes via the EP4 receptor. BMC Res Notes 3: 5 [PMID:20205862]

353. Matesanz F, González-Pérez A, Lucas M, Sanna S, Gayán J, Urcelay E, Zara I, Pitzalis M, Cavanillas ML and Arroyo R et al.. (2012) Genome-wide association study of multiple sclerosis 
confirms a novel locus at 5p13.1. PLoS One 7: e36140 [PMID:22570697]

354. Mathiesen JM, Christopoulos A, Ulven T, Royer JF, Campillo M, Heinemann A, Pardo L and Kostenis E. (2006) On the mechanism of interaction of potent surmountable and insurmountable antagonists with the prostaglandin D2 receptor CRTH2. Mol Pharmacol 69: 1441-53 [PMID:16418339]

355. Matsui Y, Amano H, Ito Y, Eshima K, Suzuki T, Ogawa F, Iyoda A, Satoh Y, Kato S and Nakamura $M$ et al.. (2012) Thromboxane A2 receptor signaling facilitates tumor colonization through Pselectin-mediated interaction of tumor cells with platelets and endothelial cells. Cancer Sci 103: 700-7 [PMID:22296266]

356. Matsumoto T, Sagawa N, Yoshida M, Mori T, Tanaka I, Mukoyama M, Kotani M and Nakao K. (1997) The prostaglandin E2 and F2 alpha receptor genes are expressed in human myometrium and are down-regulated during pregnancy. Biochem Biophys Res Commun 238: 838-841 [PMID:9325177]

357. Matsumura S, Abe T, Mabuchi T, Katano T, Takagi K, Okuda-Ashitaka E, Tatsumi S, Nakai Y, Hidaka $\mathrm{H}$ and Suzuki M et al.. (2005) Rho-kinase mediates spinal nitric oxide formation by prostaglandin E2 via EP3 subtype. Biochem Biophys Res Commun 338: 550-7 [PMID:16188227]

358. Matsuoka T, Hirata M, Tanaka H, Takahashi Y, Murata T, Kabashima K, Sugimoto Y, Kobayashi T, Ushikubi F, Aze Y, Eguchi N, Urade Y, Yoshida N, Kimura K, Mizoguchi A, Honda Y, Nagai H and Narumiya S. (2000) Prostaglandin $\mathrm{D}_{2}$ as a mediator of allergic asthma. Science 287: 20132017 [PMID:10720327]

359. Matsuoka Y, Furuyashiki T, Bito H, Ushikubi F, Tanaka Y, Kobayashi T, Muro S, Satoh N, Kayahara T and Higashi M et al.. (2003) Impaired adrenocorticotropic hormone response to bacterial endotoxin in mice deficient in prostaglandin E receptor EP1 and EP3 subtypes. Proc Natl Acad Sci USA 100: 4132-7 [PMID:12642666]

360. Matsuoka Y, Furuyashiki T, Yamada K, Nagai T, Bito H, Tanaka Y, Kitaoka S, Ushikubi F, Nabeshima T and Narumiya S. (2005) Prostaglandin E receptor EP1 controls impulsive behavior under stress. Proc Natl Acad Sci USA 102: 16066-71 [PMID:16247016]

361. Maubach KA, Davis RJ, Clark DE, Fenton G, Lockey PM, Clark KL, Oxford AW, Hagan RM, Routledge C and Coleman RA. (2009) BGC20-1531, a novel, potent and selective prostanoid EP receptor antagonist: a putative new treatment for migraine headache. Br J Pharmacol 156: 31627 [PMID:19154437]

362. Mayeux PR, Morinelli TA, Williams TC, Hazard ES, Mais DE, Oatis JE, Baron DA and Halushka PV. (1991) Differential effect of $\mathrm{pH}$ on thromboxane A2/prostaglandin $\mathrm{H} 2$ receptor agonist and antagonist binding in human platelets. J Biol Chem 266: 13752-8 [PMID:1830308]

363. McCafferty GP, Misajet BA, Laping NJ, Edwards RM and Thorneloe KS. (2008) Enhanced bladder capacity and reduced prostaglandin E2-mediated bladder hyperactivity in EP3 receptor knockout mice. Am J Physiol Renal Physiol 295: F507-14 [PMID:18508878]

364. McCoy JM, Wicks JR and Audoly LP. (2002) The role of prostaglandin E2 receptors in the pathogenesis of rheumatoid arthritis. J Clin Invest 110: 651-8 [PMID:12208866]

365. McGraw DW, Mihlbachler KA, Schwarb MR, Rahman FF, Small KM, Almoosa KF and Liggett SB. (2006) Airway smooth muscle prostaglandin-EP1 receptors directly modulate beta2-adrenergic receptors within a unique heterodimeric complex. J Clin Invest 116: 1400-9 [PMID:16670773]

366. McLaughlin VV, Archer SL, Badesch DB, Barst RJ, Farber HW, Lindner JR, Mathier MA, McGoon MD, Park MH and Rosenson RS et al.. (2009) ACCF/AHA 2009 expert consensus document on pulmonary hypertension a report of the American College of Cardiology Foundation Task Force on Expert Consensus Documents and the American Heart Association developed in collaboration with the American College of Chest Physicians; American Thoracic Society, Inc.; and the Pulmonary Hypertension Association. J Am Coll Cardiol 53: 1573-619 [PMID:19389575]

367. Meanwell NA, Romine JL, Rosenfeld MJ, Martin SW, Trehan AK, Wright JJ, Malley MF, Gougoutas JZ, Brassard CL and Buchanan JO et al.. (1993) Nonprostanoid prostacyclin mimetics. 5. Structure-activity relationships associated with [3-[4-(4,5-diphenyl-2-oxazolyl)-5oxazolyl]phenoxy]acetic acid. J Med Chem 36: 3884-903 [PMID:7504734]

368. Meanwell NA, Romine JL and Seiler SM. (1994) Non-prostanoid prostacyclin mimetics. Drugs of the Future 19: 361-385

369. Miggin SM and Kinsella BT. (2002) Investigation of the mechanisms of G protein: effector coupling by the human and mouse prostacyclin receptors. Identification of critical speciesdependent differences. J Biol Chem 277: 27053-64 [PMID:12016224]

370. Miggin SM and Kinsella BT. (2001) Thromboxane A(2) receptor mediated activation of the mitogen activated protein kinase cascades in human uterine smooth muscle cells. Biochim Biophys Acta 1539: 147-62 [PMID:11389977]

371. Miggin SM and Kinsella BT. (1998) Expression and tissue distribution of the mRNAs encoding the human thromboxane A2 receptor (TP) alpha and beta isoforms. Biochim Biophys Acta 1425: 543-59 [PMID:9838218]

372. Miki I, Kishibayashi N, Nonaka H, Ohshima E, Takami H, Obase H and Ishii A. (1992) Effects of KW-3635, a novel dibenzoxepin derivative of a selective thromboxane A2 antagonist, on human, 
guinea pig and rat platelets. Jpn J Pharmacol 59: 357-64 [PMID:1434130]

373. Minami T, Nakano H, Kobayashi T, Sugimoto Y, Ushikubi F, Ichikawa A, Narumiya S and Ito S. (2001) Characterization of EP receptor subtypes responsible for prostaglandin E2-induced pain responses by use of EP1 and EP3 receptor knockout mice. Br J Pharmacol 133: 438-44 [PMID:11375261]

374. Mitomi H, Yamada H, Ito H, Nozaki Shibata T, Yamasaki Y, Nomoto S, Kusaba A, Yamashita H and Ozaki S. (2013) Hypoxia-induced endogenous prostaglandin E2 negatively regulates hypoxia-enhanced aberrant overgrowth of rheumatoid synovial tissue. Mod Rheumatol 23: 106975 [PMID:23183906]

375. Miyamoto M, Ito H, Mukai S, Kobayashi T, Yamamoto H, Kobayashi M, Maruyama T, Akiyama H and Nakamura T. (2003) Simultaneous stimulation of EP2 and EP4 is essential to the effect of prostaglandin E2 in chondrocyte differentiation. Osteoarthr Cartil 11: 644-52 [PMID:12954235]

376. Miyaura C, Inada M, Suzawa T, Sugimoto Y, Ushikubi F, Ichikawa A, Narumiya S and Suda T. (2000) Impaired bone resorption to prostaglandin E2 in prostaglandin E receptor EP4-knockout mice. J Biol Chem 275: 19819-23 [PMID:10749873]

377. Mizoguchi A, Eguchi N, Kimura K, Kiyohara Y, Qu WM, Huang ZL, Mochizuki T, Lazarus M, Kobayashi T and Kaneko T et al.. (2001) Dominant localization of prostaglandin D receptors on arachnoid trabecular cells in mouse basal forebrain and their involvement in the regulation of non-rapid eye movement sleep. Proc Natl Acad Sci USA 98: 11674-9 [PMID:11562489]

378. Mizuguchi S, Ohno T, Hattori Y, Ae T, Minamino T, Satoh T, Arai K, Saeki T, Hayashi I and Sugimoto Y et al.. (2010) Roles of prostaglandin E2-EP1 receptor signaling in regulation of gastric motor activity and emptying. Am J Physiol Gastrointest Liver Physiol 299: G1078-86 [PMID:20798358]

379. Mjösberg JM, Trifari S, Crellin NK, Peters CP, van Drunen CM, Piet B, Fokkens WJ, Cupedo T and Spits H. (2011) Human IL-25- and IL-33-responsive type 2 innate lymphoid cells are defined by expression of CRTH2 and CD161. Nat Immunol 12: 1055-62 [PMID:21909091]

380. Molderings GJ, Colling E, Likungu J, Jakschik J and Göthert M. (1994) Modulation of noradrenaline release from the sympathetic nerves of the human saphenous vein and pulmonary artery by presynaptic EP3- and DP-receptors. Br J Pharmacol 111: 733-8 [PMID:8019753]

381. Molderings GJ, Likungu J and Göthert M. (1998) Modulation of noradrenaline release from the sympathetic nerves of human right atrial appendages by presynaptic EP3- and DP-receptors. Naunyn Schmiedebergs Arch Pharmacol 358: 440-4 [PMID:9826066]

382. Monneret G, Cossette C, Gravel S, Rokach J and Powell WS. (2003) 15R-methyl-prostaglandin D2 is a potent and selective CRTH2/DP2 receptor agonist in human eosinophils. J Pharmacol Exp Ther 304: 349-55 [PMID:12490611]

383. Montine TJ, Milatovic D, Gupta RC, Valyi-Nagy T, Morrow JD and Breyer RM. (2002) Neuronal oxidative damage from activated innate immunity is EP2 receptor-dependent. J Neurochem 83 : 463-70 [PMID:12423256]

384. Morath R, Klein T, Seyberth HW and Nüsing RM. (1999) Immunolocalization of the four prostaglandin E2 receptor proteins EP1, EP2, EP3, and EP4 in human kidney. J Am Soc Nephrol 10: 1851-60 [PMID:10477136]

385. Moreland RB, Nehra A, Kim NN, Min KS, Albadawi H, Watkins MT, Goldstein I and Traish AM. (2002) Expression of functional prostaglandin D (DP) receptors in human corpus cavernosum smooth muscle. Int J Impot Res 14: 446-52 [PMID:12494276]

386. Morimoto K, Sugimoto Y, Katsuyama M, Oida H, Tsuboi K, Kishi K, Kinoshita Y, Negishi M, Chiba T and Narumiya S et al.. (1997) Cellular localization of mRNAs for prostaglandin E receptor subtypes in mouse gastrointestinal tract. Am J Physiol 272: G681-7 [PMID:9124591]

387. Morimoto K, Suno R, Hotta Y, Yamashita K, Hirata K, Yamamoto M, Narumiya S, Iwata S and Kobayashi T. (2019) Crystal structure of the endogenous agonist-bound prostanoid receptor EP3. Nat Chem Biol 15: 8-10 [PMID:30510192]

388. Morinelli TA, Oatis JE, Okwu AK, Mais DE, Mayeux PR, Masuda A, Knapp DR and Halushka PV. (1989) Characterization of an 125I-labeled thromboxane A2/prostaglandin H2 receptor agonist. $J$ Pharmacol Exp Ther 251: 557-562 [PMID:2530338]

389. Morinelli TA, Okwu AK, Mais DE, Halushka PV, John V, Chen CK and Fried J. (1989) Difluorothromboxane A2 and stereoisomers: stable derivatives of thromboxane A2 with differential effects on platelets and blood vessels. Proc Natl Acad Sci USA 86: 5600-4 [PMID:2748606]

390. Moriyama T, Higashi T, Togashi K, Iida T, Segi E, Sugimoto Y, Tominaga T, Narumiya S and Tominaga M. (2005) Sensitization of TRPV1 by EP1 and IP reveals peripheral nociceptive mechanism of prostaglandins. Mol Pain 1: 3 [PMID:15813989]

391. Morrison SF and Nakamura K. (2011) Central neural pathways for thermoregulation. Front Biosci 16: 74-104 [PMID:21196160]

392. Morrow JD, Hill KE, Burk RF, Nammour TM, Badr KF and Roberts 2nd LJ. (1990) A series of prostaglandin F2-like compounds are produced in vivo in humans by a non-cyclooxygenase, free radical-catalyzed mechanism. Proc Natl Acad Sci USA 87: 9383-7 [PMID:2123555] 
393. Morrow JD, Minton TA, Mukundan CR, Campbell MD, Zackert WE, Daniel VC, Badr KF, Blair IA and Roberts 2nd LJ. (1994) Free radical-induced generation of isoprostanes in vivo. Evidence for the formation of D-ring and E-ring isoprostanes. J Biol Chem 269: 4317-26 [PMID:8307999]

394. Morsy MA, Isohama Y and Miyata T. (2001) Prostaglandin E(2) increases surfactant secretion via the EP(1) receptor in rat alveolar type II cells. Eur J Pharmacol 426: 21-4 [PMID:11525766]

395. Mosher AA, Rainey KJ, Giembycz MA, Wood S and Slater DM. (2012) Prostaglandin E2 represses interleukin 1 beta-induced inflammatory mediator output from pregnant human myometrial cells through the EP2 and EP4 receptors. Biol Reprod 87: 7, 1-10 [PMID:22517618]

396. Mu J, Kanzaki T, Si X, Tomimatsu T, Fukuda H, Fujii E, Hosono T, Murata Y, Sugimoto Y and Ichikawa A. (2002) Apoptosis and related proteins during parturition in prostaglandin $F$ receptor-deficient mice. Biochem Biophys Res Commun 292: 675-681 [PMID:11922619]

397. Mu J, Kanzaki T, Si X, Tomimatsu T, Fukuda H, Shioji M, Murata Y, Sugimoto Y and Ichikawa A. (2003) Apoptosis and related proteins in placenta of intrauterine fetal death in prostaglandin $f$ receptor-deficient mice. Biol Reprod 68: 1968-74 [PMID:12606450]

398. Mu J, Kanzaki T, Tomimatsu T, Fukuda H, Wasada K, Fujii E, Endoh M, Kozuki M, Murata Y and Sugimoto $\mathrm{Y}$ et al.. (2002) Expression of apoptosis in placentae from mice lacking the prostaglandin F receptor. Placenta 23: 215-23 [PMID:11945089]

399. Mukhopadhyay P, Bian L, Yin H, Bhattacherjee P and Paterson C. (2001) Localization of EP(1) and FP receptors in human ocular tissues by in situ hybridization. Invest Ophthalmol Vis Sci 42: 424-8 [PMID:11157877]

400. Mulvaney EP, O'Sullivan ÁG, Eivers SB, Reid HM and Kinsella BT. (2019) Differential expression of the TP $\alpha$ and TP $\beta$ isoforms of the human T Prostanoid receptor during chronic inflammation of the prostate: Role for FOXP1 in the transcriptional regulation of TP $\beta$ during monocytemacrophage differentiation. Exp Mol Pathol 110: 104277 [PMID:31271729]

401. Mulvaney EP, Reid HM, Bialesova L, Mendes-Ferreira P, Adão R, Brás-Silva C and Kinsella BT. (2020) Efficacy of the thromboxane receptor antagonist NTP42 alone, or in combination with sildenafil, in the sugen/hypoxia-induced model of pulmonary arterial hypertension. Eur J Pharmacol 889: 173658 [PMID:33121950]

402. Mumford AD, Dawood BB, Daly ME, Murden SL, Williams MD, Protty MB, Spalton JC, Wheatley M, Mundell SJ and Watson SP. (2010) A novel thromboxane A2 receptor D304N variant that abrogates ligand binding in a patient with a bleeding diathesis. Blood 115: 363-9 [PMID:19828703]

403. Mumford AD, Nisar S, Darnige L, Jones ML, Bachelot-Loza C, Gandrille S, Zinzindohoue F, Fischer AM, Mundell SJ and Gaussem P et al.. (2013) Platelet dysfunction associated with the novel Trp29Cys thromboxane A2 receptor variant. J Thromb Haemost 11: 547-54 [PMID:23279270]

404. Murase A, Okumura T, Sakakibara A, Tonai-Kachi H, Nakao K and Takada J. (2008) Effect of prostanoid EP4 receptor antagonist, CJ-042,794, in rat models of pain and inflammation. Eur J Pharmacol 580: 116-21 [PMID:18031725]

405. Murase A, Taniguchi Y, Tonai-Kachi H, Nakao K and Takada J. (2008) In vitro pharmacological characterization of CJ-042794, a novel, potent, and selective prostaglandin $\mathrm{EP}(4)$ receptor antagonist. Life Sci 82: 226-32 [PMID:18155068]

406. Murata T, Lin MI, Aritake K, Matsumoto S, Narumiya S, Ozaki H, Urade Y, Hori M and Sessa WC. (2008) Role of prostaglandin D2 receptor DP as a suppressor of tumor hyperpermeability and angiogenesis in vivo. Proc Natl Acad Sci USA 105: 20009-14 [PMID:19060214]

407. Murata T, Ushikubi F, Matsuoka T, Hirata M, Yamasaki A, Sugimoto Y, Ichikawa A, Aze Y, Tanaka T and Yoshida $\mathrm{N}$ et al.. (1997) Altered pain perception and inflammatory response in mice lacking prostacyclin receptor. Nature 388: 678-82 [PMID:9262402]

408. Murn J, Alibert O, Wu N, Tendil S and Gidrol X. (2008) Prostaglandin E2 regulates B cell proliferation through a candidate tumor suppressor, Ptger4. J Exp Med 205: 3091-103 [PMID:19075289]

409. Mutoh M, Watanabe K, Kitamura T, Shoji Y, Takahashi M, Kawamori T, Tani K, Kobayashi M, Maruyama T and Kobayashi K et al.. (2002) Involvement of prostaglandin E receptor subtype EP(4) in colon carcinogenesis. Cancer Res 62: 28-32 [PMID:11782353]

410. Myren M, Baun M, Ploug KB, Jansen-Olesen I, Olesen J and Gupta S. (2010) Functional and molecular characterization of prostaglandin E2 dilatory receptors in the rat craniovascular system in relevance to migraine. Cephalalgia 30: 1110-22 [PMID:20713561]

411. Müller K, Krieg P, Marks F and Fürstenberger G. (2000) Expression of PGF(2alpha) receptor mRNA in normal, hyperplastic and neoplastic skin. Carcinogenesis 21: 1063-6 [PMID:10783334]

412. Nagamachi M, Sakata D, Kabashima K, Furuyashiki T, Murata T, Segi-Nishida E, Soontrapa K, Matsuoka T, Miyachi Y and Narumiya S. (2007) Facilitation of Th1-mediated immune response by prostaglandin E receptor EP1. J Exp Med 204: 2865-74 [PMID:17967902]

413. Nagao K, Tanaka H, Komai M, Masuda T, Narumiya S and Nagai H. (2003) Role of prostaglandin I2 in airway remodeling induced by repeated allergen challenge in mice. Am J Respir Cell Mol Biol 29: 314-20 [PMID:12676807] 
414. Nagata K, Hirai H, Tanaka K, Ogawa K, Aso T, Sugamura K, Nakamura M and Takano S. (1999) CRTH2, an orphan receptor of T-helper-2-cells, is expressed on basophils and eosinophils and responds to mast cell-derived factor(s). FEBS Lett 459: 195-9 [PMID:10518017]

415. Nagata K, Tanaka K, Ogawa K, Kemmotsu K, Imai T, Yoshie O, Abe H, Tada K, Nakamura M and Sugamura K et al.. (1999) Selective expression of a novel surface molecule by human Th2 cells in vivo. J Immunol 162: 1278-86 [PMID:9973380]

416. Naka M, Mais DE, Morinelli TA, Hamanaka N, Oatis Jr JE and Halushka PV. (1992) 7[(1R,2S,3S,5R)-6,6-dimethyl-3-(4- iodobenzenesulfonylamino)bicyclo[3.1.1]hept-2-yl]-5(Z)heptenoic acid: a novel high-affinity radiolabeled antagonist for platelet thromboxane A2/prostaglandin H2 receptors. J Pharmacol Exp Ther 262: 632-7 [PMID:1386885]

417. Nakae K, Hayashi F, Hayashi M, Yamamoto N, Iino T, Yoshikawa S and Gupta J. (2005) Functional role of prostacyclin receptor in rat dorsal root ganglion neurons. Neurosci Lett 388: 132-137 [PMID:16039053]

418. Nakae K, Saito K, Iino T, Yamamoto N, Wakabayashi M, Yoshikawa S, Matsushima S, Miyashita $\mathrm{H}$, Sugimoto H and Kiba A et al.. (2005) A prostacyclin receptor antagonist inhibits the sensitized release of substance P from rat sensory neurons. J Pharmacol Exp Ther 315: 1136-42 [PMID:16109742]

419. Nakagawa N, Yuhki K, Kawabe J, Fujino T, Takahata O, Kabara M, Abe K, Kojima F, Kashiwagi H and Hasebe $\mathrm{N}$ et al.. (2012) The intrinsic prostaglandin E2-EP4 system of the renal tubular epithelium limits the development of tubulointerstitial fibrosis in mice. Kidney Int 82: 158-71 [PMID:22513820]

420. Nakagawa O, Tanaka I, Usui T, Harada M, Sasaki Y, Itoh H, Yoshimasa T, Namba T, Narumiya S and Nakao K. (1994) Molecular cloning of human prostacyclin receptor cDNA and its gene expression in the cardiovascular system. Circulation 90: 1643-7 [PMID:7923647]

421. Nakajima S, Honda T, Sakata D, Egawa G, Tanizaki H, Otsuka A, Moniaga CS, Watanabe T, Miyachi Y and Narumiya S et al.. (2010) Prostaglandin I2-IP signaling promotes Th1 differentiation in a mouse model of contact hypersensitivity. J Immunol 184: 5595-603 [PMID:20400695]

422. Nakamura K, Kaneko T, Yamashita Y, Hasegawa H, Katoh H, Ichikawa A and Negishi M. (1999) Immunocytochemical localization of prostaglandin EP3 receptor in the rat hypothalamus. Neurosci Lett 260: 117-20 [PMID:10025713]

423. Nakao A, Watanabe T, Taniguchi S, Nakamura M, Honda Z, Shimizu T and Kurokawa K. (1993) Characterization of prostaglandin F2 alpha receptor of mouse 3T3 fibroblasts and its functional expression in Xenopus laevis oocytes. J Cell Physiol 155: 257-264 [PMID:8482718]

424. Nakao K, Murase A, Ohshiro H, Okumura T, Taniguchi K, Murata Y, Masuda M, Kato T, Okumura Y and Takada J. (2007) CJ-023,423, a novel, potent and selective prostaglandin EP4 receptor antagonist with antihyperalgesic properties. J Pharmacol Exp Ther 322: 686-94 [PMID:17495127]

425. Nakayama Y, Omote K and Namiki A. (2002) Role of prostaglandin receptor EP1 in the spinal dorsal horn in carrageenan-induced inflammatory pain. Anesthesiology 97: 1254-62 [PMID:12411813]

426. Namba T, Oida H, Sugimoto Y, Kakizuka A, Negishi M, Ichikawa A and Narumiya S. (1994) cDNA cloning of a mouse prostacyclin receptor. Multiple signaling pathways and expression in thymic medulla. J Biol Chem 269: 9986-92 [PMID:7511597]

427. Namba T, Sugimoto Y, Hirata M, Hayashi Y, Honda A, Watabe A, Negishi M, Ichikawa A and Narumiya S. (1992) Mouse thromboxane A2 receptor: cDNA cloning, expression and northern blot analysis. Biochem Biophys Res Commun 184: 1197-203 [PMID:1375456]

428. Namba T, Sugimoto Y, Negishi M, Irie A, Ushikubi F, Kakizuka A, Ito S, Ichikawa A and Narumiya S. (1993) Alternative splicing of C-terminal tail of prostaglandin E receptor subtype EP3 determines G-protein specificity. Nature 365: 166-70 [PMID:8396726]

429. Narumiya S. (2009) Prostanoids and inflammation: a new concept arising from receptor knockout mice. J Mol Med 87: 1015-22 [PMID:19609495]

430. Nataraj C, Thomas DW, Tilley SL, Nguyen MT, Mannon R, Koller BH and Coffman TM. (2001) Receptors for prostaglandin $\mathrm{E}(2)$ that regulate cellular immune responses in the mouse. J Clin Invest 108: 1229-35 [PMID:11602631]

431. Negishi M, Irie A, Sugimoto Y, Namba T and Ichikawa A. (1995) Selective coupling of prostaglandin E receptor EP3D to Gi and Gs through interaction of alpha-carboxylic acid of agonist and arginine residue of seventh transmembrane domain. J Biol Chem 270: 16122-7 [PMID:7608175]

432. Negishi M, Sugimoto Y, Irie A, Narumiya S and Ichikawa A. (1993) Two isoforms of prostaglandin E receptor EP3 subtype. Different $\mathrm{COOH}$-terminal domains determine sensitivity to agonist-induced desensitization. J Biol Chem 268: 9517-21 [PMID:8387497]

433. Nemoto K, Pilbeam CC, Bilak SR and Raisz LG. (1997) Molecular cloning and expression of a rat prostaglandin E2 receptor of the EP2 subtype. Prostaglandins 54: 713-25 [PMID:9440134]

434. Neuschäfer-Rube F, DeVries C, Hänecke K, Jungermann K and Püschel GP. (1994) Molecular 
cloning and expression of a prostaglandin E2 receptor of the EP3 beta subtype from rat hepatocytes. FEBS Lett 351: 119-22 [PMID:8076679]

435. Neuschäfer-Rube F, Engemaier E, Koch S, Böer U and Püschel GP. (2003) Identification by sitedirected mutagenesis of amino acids contributing to ligand-binding specificity or signal transduction properties of the human FP prostanoid receptor. Biochem J 371: 443-9 [PMID:12519077]

436. Neuschäfer-Rube F, Hermosilla R, Kuna M, Pathe-Neuschäfer-Rube A, Schülein R and Püschel GP. (2005) A Ser/Thr cluster within the C-terminal domain of the rat prostaglandin receptor EP3alpha is essential for agonist-induced phosphorylation, desensitization and internalization. Br J Pharmacol 145: 1132-42 [PMID:15937517]

437. Neuschäfer-Rube F, Hänecke K, Blaschke V, Jungermann K and Püschel GP. (1997) The Cterminal domain of the Gs-coupled EP4 receptor confers agonist-dependent coupling control to Gi but no coupling to Gs in a receptor hybrid with the Gi-coupled EP3 receptor. FEBS Lett 401: 185-90 [PMID:9013884]

438. $\mathrm{Ng} \mathrm{KY,} \mathrm{Wong} \mathrm{YH} \mathrm{and} \mathrm{Wise} \mathrm{H.} \mathrm{(2011)} \mathrm{Glial} \mathrm{cells} \mathrm{isolated} \mathrm{from} \mathrm{dorsal} \mathrm{root} \mathrm{ganglia} \mathrm{express}$ prostaglandin E(2) (EP(4)) and prostacyclin (IP) receptors. Eur J Pharmacol 661: 42-8 [PMID:21549696]

439. Ngoc PB, Suzuki J, Ogawa M, Hishikari K, Takayama K, Hirata Y, Nagai R and Isobe M. (2011) The anti-inflammatory mechanism of prostaglandin e2 receptor 4 activation in rat experimental autoimmune myocarditis. J Cardiovasc Pharmacol 57: 365-72 [PMID:21383594]

440. Nguyen M, Camenisch T, Snouwaert JN, Hicks E, Coffman TM, Anderson PA, Malouf NN and Koller BH. (1997) The prostaglandin receptor EP4 triggers remodelling of the cardiovascular system at birth. Nature 390: 78-81 [PMID:9363893]

441. Nie D, Guo Y, Yang D, Tang Y, Chen Y, Wang MT, Zacharek A, Qiao Y, Che M and Honn KV. (2008) Thromboxane A2 receptors in prostate carcinoma: expression and its role in regulating cell motility via small GTPase Rho. Cancer Res 68: 115-21 [PMID:18172303]

442. Nishio H, Terashima S, Nakashima M, Aihara E and Takeuchi K. (2007) Involvement of prostaglandin E receptor EP3 subtype and prostacyclin IP receptor in decreased acid response in damaged stomach. J Physiol Pharmacol 58: 407-21 [PMID:17928639]

443. Nishitani K, Ito H, Hiramitsu T, Tsutsumi R, Tanida S, Kitaori T, Yoshitomi H, Kobayashi M and Nakamura T. (2010) PGE2 inhibits MMP expression by suppressing MKK4-JNK MAP kinase-cJUN pathway via EP4 in human articular chondrocytes. J Cell Biochem 109: 425-33 [PMID:19998410]

444. Noguchi E, Shibasaki M, Kamioka M, Yokouchi Y, Yamakawa-Kobayashi K, Hamaguchi H, Matsui A and Arinami T. (2002) New polymorphisms of haematopoietic prostaglandin D synthase and human prostanoid DP receptor genes. Clin Exp Allergy 32: 93-6 [PMID:12002745]

445. Noguchi K, Shitashige M, Endo H, Kondo H and Ishikawa I. (2002) Binary regulation of interleukin (IL)-6 production by EP1 and EP2/EP4 subtypes of PGE2 receptors in IL-1betastimulated human gingival fibroblasts. J Periodont Res 37: 29-36 [PMID:11842936]

446. Nojima S, Fujita Y, Kimura KT, Nomura N, Suno R, Morimoto K, Yamamoto M, Noda T, Iwata S and Shigematsu H et al.. (2021) Cryo-EM Structure of the Prostaglandin E Receptor EP4 Coupled to G Protein. Structure 29: 252-260.e6 [PMID:33264604]

447. Norel X, de Montpreville V and Brink C. (2004) Vasoconstriction induced by activation of EP1 and EP3 receptors in human lung: effects of ONO-AE-248, ONO-DI-004, ONO-8711 or ONO8713. Prostaglandins Other Lipid Mediat 74: 101-12 [PMID:15560119]

448. Norel X, Sugimoto Y, Ozen G, Abdelazeem H, Amgoud Y, Bouhadoun A, Bassiouni W, Goepp M, Mani S and Manikpurage HD et al.. (2020) International Union of Basic and Clinical Pharmacology. CIX. Differences and Similarities between Human and Rodent Prostaglandin $\mathrm{E}_{2}$ Receptors (EP1-4) and Prostacyclin Receptor (IP): Specific Roles in Pathophysiologic Conditions. Pharmacol Rev 72: 910-968 [PMID:32962984]

449. Norel X, Walch L, Labat C, Gascard JP, Dulmet E and Brink C. (1999) Prostanoid receptors involved in the relaxation of human bronchial preparations. Br J Pharmacol 126: 867-72 [PMID:10193766]

450. Nüsing RM, Treude A, Weissenberger C, Jensen B, Bek M, Wagner C, Narumiya S and Seyberth HW. (2005) Dominant role of prostaglandin E2 EP4 receptor in furosemide-induced salt-losing tubulopathy: a model for hyperprostaglandin E syndrome/antenatal Bartter syndrome. J Am Soc Nephrol 16: 2354-62 [PMID:15976003]

451. Oga T, Matsuoka T, Yao C, Nonomura K, Kitaoka S, Sakata D, Kita Y, Tanizawa K, Taguchi Y and Chin K et al.. (2009) Prostaglandin F(2alpha) receptor signaling facilitates bleomycin-induced pulmonary fibrosis independently of transforming growth factor-beta. Nat Med 15: 1426-30 [PMID:19966781]

452. Ogletree ML and Allen GT. (1992) Interspecies differences in thromboxane receptors: studies with thromboxane receptor antagonists in rat and guinea-pig smooth muscles. J Pharmacol Exp Ther 260: 789-794 [PMID:1531361]

453. Ogletree ML, Harris DN, Greenberg R, Haslanger MF and Nakane M. (1985) Pharmacological 
actions of SQ 29,548, a novel selective thromboxane antagonist. J Pharmacol Exp Ther 234: 43541 [PMID:3926986]

454. Ogletree ML, Harris DN, Schumacher WA, Webb ML and Misra RN. (1993) Pharmacological profile of BMS 180,291: a potent, long-acting, orally active thromboxane A2/prostaglandin endoperoxide receptor antagonist. J Pharmacol Exp Ther 264: 570-8 [PMID:8437108]

455. Oguma T, Palmer LJ, Birben E, Sonna LA, Asano K and Lilly CM. (2004) Role of prostanoid DP receptor variants in susceptibility to asthma. $N$ Engl J Med 351: 1752-63 [PMID:15496624]

456. Ohno T, Katori M, Majima M, Saeki T, Boku K, Nishiyama K, Hayashi H and Saigenji K. (1999) Dilatation and constriction of rat gastric mucosal microvessels through prostaglandin EP2 and EP3 receptors. Aliment Pharmacol Ther 13: 1243-50 [PMID:10468708]

457. Oida H, Hirata M, Sugimoto Y, Ushikubi F, Ohishi H, Mizuno N, Ichikawa A and Narumiya S. (1997) Expression of messenger RNA for the prostaglandin D receptor in the leptomeninges of the mouse brain. FEBS Lett 417: 53-6 [PMID:9395073]

458. Oka T, Aou S and Hori T. (1994) Intracerebroventricular injection of prostaglandin E2 induces thermal hyperalgesia in rats: the possible involvement of EP3 receptors. Brain Res 663: 287-92 [PMID:7874513]

459. Oka T and Hori T. (1994) EP1-receptor mediation of prostaglandin E2-induced hyperthermia in rats. Am J Physiol 267: R289-94 [PMID:7914071]

460. Oka T, Hori T, Hosoi M, Oka K, Abe M and Kubo C. (1997) Biphasic modulation in the trigeminal nociceptive neuronal responses by the intracerebroventricular prostaglandin E2 may be mediated through different EP receptors subtypes in rats. Brain Res 771: 278-84 [PMID:9401748]

461. Oka T, Oka K, Kobayashi T, Sugimoto Y, Ichikawa A, Ushikubi F, Narumiya S and Saper CB. (2003) Characteristics of thermoregulatory and febrile responses in mice deficient in prostaglandin EP1 and EP3 receptors. J Physiol 551: 945-954 [PMID:12837930]

462. Okada Y, Hara A, Ma H, Xiao CY, Takahata O, Kohgo Y, Narumiya S and Ushikubi F. (2000) Characterization of prostanoid receptors mediating contraction of the gastric fundus and ileum: studies using mice deficient in prostanoid receptors. Br J Pharmacol 131: 745-55 [PMID:11030724]

463. Okada Y, Taniguchi T, Morishima S, Suzuki F, Akagi Y and Muramatsu I. (2006) Characteristics of acid extrusion from Chinese hamster ovary cells expressing different prostaglandin EP receptors. Life Sci 78: 2454-62 [PMID:16300797]

464. Okamoto F, Kajiya H, Fukushima H, Jimi E and Okabe K. (2004) Prostaglandin E2 activates outwardly rectifying $\mathrm{Cl}(-)$ channels via a cAMP-dependent pathway and reduces cell motility in rat osteoclasts. Am J Physiol, Cell Physiol 287: C114-24 [PMID:15044156]

465. Okuda-Ashitaka E, Sakamoto K, Ezashi T, Miwa K, Ito S and Hayaishi O. (1996) Suppression of prostaglandin E receptor signaling by the variant form of EP1 subtype. J Biol Chem 271: 3125561 [PMID:8940129]

466. Oldfield S, Grubb BD and Donaldson LF. (2001) Identification of a prostaglandin E2 receptor splice variant and its expression in rat tissues. Prostaglandins Other Lipid Mediat 63: 165-73 [PMID:11305694]

467. Olofsson JI, Leung CH, Bjurulf E, Ohno T, Selstam G, Peng C and Leung PC. (1996) Characterization and regulation of a mRNA encoding the prostaglandin F2alpha receptor in the rat ovary. Mol Cell Endocrinol 123: 45-52 [PMID:8912810]

468. Ono K, Akatsu T, Kugai N, Pilbeam CC and Raisz LG. (2003) The effect of deletion of cyclooxygenase-2, prostaglandin receptor EP2, or EP4 in bone marrow cells on osteoclasts induced by mouse mammary cancer cell lines. Bone 33: 798-804 [PMID:14623055]

469. Orie NN, Ledwozyw A, Williams DJ, Whittle BJ and Clapp LH. (2013) Differential actions of the prostacyclin analogues treprostinil and iloprost and the selexipag metabolite, MRE-269 (ACT333679) in rat small pulmonary arteries and veins. Prostaglandins Other Lipid Mediat 106: 1-7 [PMID:23872196]

470. Orlicky DJ, Fisher L, Dunscomb N and Miller GJ. (1992) Immunohistochemical localization of PGF2 alpha receptor in the rat ovary. Prostaglandins Leukot Essent Fatty Acids 46: 223-9 [PMID:1508956]

471. Ota T, Aihara M, Narumiya S and Araie M. (2005) The effects of prostaglandin analogues on IOP in prostanoid FP-receptor-deficient mice. Invest Ophthalmol Vis Sci 46: 4159-63 [PMID:16249494]

472. Palikhe NS, Sin HJ, Kim SH, Sin HJ, Hwang EK, Ye YM and Park HS. (2012) Genetic variability of prostaglandin E2 receptor subtype EP4 gene in aspirin-intolerant chronic urticaria. J Hum Genet 57: 494-9 [PMID:22695889]

473. Paralkar VM, Borovecki F, Ke HZ, Cameron KO, Lefker B, Grasser WA, Owen TA, Li M, DaSilvaJardine P and Zhou M et al.. (2003) An EP2 receptor-selective prostaglandin E2 agonist induces bone healing. Proc Natl Acad Sci USA 100: 6736-40 [PMID:12748385]

474. Patrignani P, Di Febbo C, Tacconelli S, Douville K, Guglielmi MD, Horvath RJ, Ding M, Sierra K, Stitham J and Gleim S et al.. (2008) Differential association between human prostacyclin 
receptor polymorphisms and the development of venous thrombosis and intimal hyperplasia: a clinical biomarker study. Pharmacogenet Genomics 18: 611-20 [PMID:18551041]

475. Patrono C and Roth GJ. (1996) Aspirin in ischemic cerebrovascular disease. How strong is the case for a different dosing regimen? Stroke 27: 756-60 [PMID:8614944]

476. Peri KG, Quiniou C, Hou X, Abran D, Varma DR, Lubell WD and Chemtob S. (2002) THG113: a novel selective FP antagonist that delays preterm labor. Semin Perinatol 26: 389-97 [PMID:12537309]

477. Pettipher R. (2008) The roles of the prostaglandin D(2) receptors DP(1) and CRTH2 in promoting allergic responses. Br J Pharmacol 153 Suppl 1: S191-9 [PMID:17965752]

478. Pettipher R, Hunter MG, Perkins CM, Collins LP, Lewis T, Baillet M, Steiner J, Bell J and Payton MA. (2014) Heightened response of eosinophilic asthmatic patients to the CRTH2 antagonist OC000459. Allergy 69: 1223-32 [PMID:24866478]

479. Pettipher R, Vinall SL, Xue L, Speight G, Townsend ER, Gazi L, Whelan CJ, Armer RE, Payton MA and Hunter MG. (2012) Pharmacologic profile of OC000459, a potent, selective, and orally active D prostanoid receptor 2 antagonist that inhibits mast cell-dependent activation of $\mathrm{T}$ helper 2 lymphocytes and eosinophils. J Pharmacol Exp Ther 340: 473-82 [PMID:22106101]

480. Philipose S, Konya V, Sreckovic I, Marsche G, Lippe IT, Peskar BA, Heinemann A and Schuligoi R. (2010) The prostaglandin E2 receptor EP4 is expressed by human platelets and potently inhibits platelet aggregation and thrombus formation. Arterioscler Thromb Vasc Biol 30: 241623 [PMID:21071691]

481. Pierce KL, Bailey TJ, Hoyer PB, Gil DW, Woodward DF and Regan JW. (1997) Cloning of a carboxyl-terminal isoform of the prostanoid FP receptor. J Biol Chem 272: 883-7 [PMID:8995377]

482. Poloso NJ, Urquhart P, Nicolaou A, Wang J and Woodward DF. (2013) PGE2 differentially regulates monocyte-derived dendritic cell cytokine responses depending on receptor usage (EP2/EP4). Mol Immunol 54: 284-95 [PMID:23337716]

483. Prasanna G, Carreiro S, Anderson S, Gukasyan H, Sartnurak S, Younis H, Gale D, Xiang C, Wells P and Dinh D et al.. (2011) Effect of PF-04217329 a prodrug of a selective prostaglandin EP(2) agonist on intraocular pressure in preclinical models of glaucoma. Exp Eye Res 93: 256-64 [PMID:21376717]

484. Prasanna G, Fortner J, Xiang C, Zhang E, Carreiro S, Anderson S, Sartnurak S, Wu G, Gukasyan $\mathrm{H}$ and Niesman $\mathrm{M}$ et al.. (2009) Ocular pharmacokinetics and hypotensive activity of PF04475270, an EP4 prostaglandin agonist in preclinical models. Exp Eye Res 89: 608-17 [PMID:19445930]

485. Praticò D, Smyth EM, Violi F and FitzGerald GA. (1996) Local amplification of platelet function by 8-Epi prostaglandin F2alpha is not mediated by thromboxane receptor isoforms. J Biol Chem 271: 14916-24 [PMID:8663015]

486. Pulichino AM, Rowland S, Wu T, Clark P, Xu D, Mathieu MC, Riendeau D and Audoly LP. (2006) Prostacyclin antagonism reduces pain and inflammation in rodent models of hyperalgesia and chronic arthritis. J Pharmacol Exp Ther 319: 1043-50 [PMID:16973887]

487. Purdy KE and Arendshorst WJ. (2000) EP(1) and EP(4) receptors mediate prostaglandin E(2) actions in the microcirculation of rat kidney. Am J Physiol Renal Physiol 279: F755-64 [PMID:10997926]

488. Pönicke K, Giessler C, Grapow M, Heinroth-Hoffmann I, Becker K, Osten B and Brodde OE. (2000) FP-receptor mediated trophic effects of prostanoids in rat ventricular cardiomyocytes. $\mathrm{Br}$ J Pharmacol 129: 1723-31 [PMID:10780979]

489. Pöschke A, Kern N, Maruyama T, Pavenstädt H, Narumiya S, Jensen BL and Nüsing RM. (2012) The PGE(2)-EP4 receptor is necessary for stimulation of the renin-angiotensin-aldosterone system in response to low dietary salt intake in vivo. Am J Physiol Renal Physiol 303: F1435-42 [PMID:22993066]

490. Qian JY, Harding P, Liu Y, Shesely E, Yang XP and LaPointe MC. (2008) Reduced cardiac remodeling and function in cardiac-specific EP4 receptor knockout mice with myocardial infarction. Hypertension 51: 560-6 [PMID:18180401]

491. Qian YM, Jones RL, Chan KM, Stock AI and Ho JK. (1994) Potent contractile actions of prostanoid EP3-receptor agonists on human isolated pulmonary artery. BrJ Pharmacol 113: 369-74 [PMID:7834185]

492. Qiao N, Reynaud D, Demin P, Halushka PV and Pace-Asciak CR. (2003) The thromboxane receptor antagonist PBT-3, a hepoxilin stable analog, selectively antagonizes the TPalpha isoform in transfected COS-7 cells. J Pharmacol Exp Ther 307: 1142-7 [PMID:14560042]

493. Rachmilewitz D, Chapman JW and Nicholson PA. (1986) A multicenter international controlled comparison of two dosage regimens of misoprostol with cimetidine in treatment of gastric ulcer in outpatients. Dig Dis Sci 31: 75S-80S [PMID:3080293]

494. Racké K, Bähring J, Langer C, Bräutigam M and Wessler I. (1992) Prostanoids inhibit release of endogenous norepinephrine from rat isolated trachea. Am Rev Respir Dis 146: 1182-6 [PMID:1443867] 
495. Ratcliffe MJ, Walding A, Shelton PA, Flaherty A and Dougall IG. (2007) Activation of Eprostanoid4 and E-prostanoid2 receptors inhibits TNF-alpha release from human alveolar macrophages. Eur Respir J 29: 986-94 [PMID:17331962]

496. Rausch-Derra L, Huebner M, Wofford J and Rhodes L. (2016) A Prospective, Randomized, Masked, Placebo-Controlled Multisite Clinical Study of Grapiprant, an EP4 Prostaglandin Receptor Antagonist (PRA), in Dogs with Osteoarthritis. J Vet Intern Med 30: 756-63 [PMID:27075237]

497. Raychowdhury MK, Yukawa M, Collins LJ, McGrail SH, Kent KC and Ware JA. (1994) Alternative splicing produces a divergent cytoplasmic tail in the human endothelial thromboxane A2 receptor. J Biol Chem 269: 19256-61 [PMID:8034687]

498. Raymond V, Leung PC and Labrie F. (1983) Stimulation by prostaglandin F2 alpha of phosphatidic acid-phosphatidylinositol turnover in rat luteal cells. Biochem Biophys Res Commun 116: 39-46 [PMID:6357198]

499. Reader J, Holt D and Fulton A. (2011) Prostaglandin E2 EP receptors as therapeutic targets in breast cancer. Cancer Metastasis Rev 30: 449-63 [PMID:22002714]

500. Regan JW, Bailey TJ, Donello JE, Pierce KL, Pepperl DJ, Zhang D, Kedzie KM, Fairbairn CE, Bogardus AM and Woodward DF et al.. (1994) Molecular cloning and expression of human EP3 receptors: evidence of three variants with differing carboxyl termini. Br J Pharmacol 112: 37785 [PMID:8075855]

501. Regan JW, Bailey TJ, Pepperl DJ, Pierce KL, Bogardus AM, Donello JE, Fairbairn CE, Kedzie KM, Woodward DF and Gil DW. (1994) Cloning of a novel human prostaglandin receptor with characteristics of the pharmacologically defined EP2 subtype. Mol Pharmacol 46: 213-20 [PMID:8078484]

502. Reinheimer T, Harnack E, Racke K and Wessler I. (1998) Prostanoid receptors of the EP3 subtype mediate inhibition of evoked [3H]acetylcholine release from isolated human bronchi. $\mathrm{Br}$ J Pharmacol 125: 271-6 [PMID:9786498]

503. Reinold H, Ahmadi S, Depner UB, Layh B, Heindl C, Hamza M, Pahl A, Brune K, Narumiya S and Müller U et al.. (2005) Spinal inflammatory hyperalgesia is mediated by prostaglandin E receptors of the EP2 subtype. J Clin Invest 115: 673-9 [PMID:15719070]

504. Ritchie RH, Rosenkranz AC, Huynh LP, Stephenson T, Kaye DM and Dusting GJ. (2004) Activation of IP prostanoid receptors prevents cardiomyocyte hypertrophy via cAMP-dependent signaling. Am J Physiol Heart Circ Physiol 287: H1179-85 [PMID:15072955]

505. Robb CT, McSorley HJ, Lee J, Aoki T, Yu C, Crittenden S, Astier A, Felton JM, Parkinson N and Ayele A et al.. (2018) Prostaglandin $\mathrm{E}_{2}$ stimulates adaptive IL-22 production and promotes allergic contact dermatitis. J Allergy Clin Immunol 141: 152-162 [PMID:28583370]

506. Rocha PN, Plumb TJ, Robinson LA, Spurney R, Pisetsky D, Koller BH and Coffman TM. (2005) Role of thromboxane A2 in the induction of apoptosis of immature thymocytes by lipopolysaccharide. Clin Diagn Lab Immunol 12: 896-903 [PMID:16085905]

507. Root JA, Davey DA and Af Forselles KJ. (2015) Prostanoid receptors mediating contraction in rat, macaque and human bladder smooth muscle in vitro. Eur J Pharmacol 769: 274-9 [PMID:26607459]

508. Rosenfield AR, Lowman RM and Taylor KJ. (1976) Urography in preoperative evaluation of abdominal aortic aneurysms. Urology 7: 652-4 [PMID:936389]

509. Royer JF, Schratl P, Lorenz S, Kostenis E, Ulven T, Schuligoi R, Peskar BA and Heinemann A. (2007) A novel antagonist of CRTH2 blocks eosinophil release from bone marrow, chemotaxis and respiratory burst. Allergy 62: 1401-9 [PMID:17714552]

510. Ruel R, Lacombe P, Abramovitz M, Godbout C, Lamontagne S, Rochette C, Sawyer N, Stocco R, Tremblay NM and Metters KM et al.. (1999) New class of biphenylene dibenzazocinones as potent ligands for the human EP1 prostanoid receptor. Bioorg Med Chem Lett 9: 2699-704 [PMID:10509919]

511. Rundhaug JE, Simper MS, Surh I and Fischer SM. (2011) The role of the EP receptors for prostaglandin E2 in skin and skin cancer. Cancer Metastasis Rev 30: 465-80 [PMID:22012553]

512. Saeki T, Ota T, Aihara M and Araie M. (2009) Effects of prostanoid EP agonists on mouse intraocular pressure. Invest Ophthalmol Vis Sci 50: 2201-8 [PMID:19117925]

513. Saito O, Guan Y, Qi Z, Davis LS, Kömhoff M, Sugimoto Y, Narumiya S, Breyer RM and Breyer MD. (2003) Expression of the prostaglandin F receptor (FP) gene along the mouse genitourinary tract. Am J Physiol Renal Physiol 284: F1164-70 [PMID:12631554]

514. Sakai M, Minami T, Hara N, Nishihara I, Kitade H, Kamiyama Y, Okuda K, Takahashi H, Mori H and Ito S. (1998) Stimulation of nitric oxide release from rat spinal cord by prostaglandin E2. $\mathrm{Br}$ J Pharmacol 123: 890-894 [PMID:9535017]

515. Sakamoto K, Ezashi T, Miwa K, Okuda-Ashitaka E, Houtani T, Sugimoto T, Ito S and Hayaishi O. (1994) Molecular cloning and expression of a cDNA of the bovine prostaglandin F2 alpha receptor. J Biol Chem 269: 3881-6 [PMID:7508922]

516. Sakuma Y, Tanaka K, Suda M, Komatsu Y, Yasoda A, Miura M, Ozasa A, Narumiya S, Sugimoto Y and Ichikawa A et al.. (2000) Impaired bone resorption by lipopolysaccharide in vivo in mice 
deficient in the prostaglandin E receptor EP4 subtype. Infect Immun 68: 6819-25

[PMID:11083800]

517. Saleem S, Shah ZA, Maruyama T, Narumiya S and Doré S. (2010) Neuroprotective properties of prostaglandin I2 IP receptor in focal cerebral ischemia. Neuroscience 170: 317-23 [PMID:20621166]

518. Sando T, Usui T, Tanaka I, Mori K, Sasaki Y, Fukuda Y, Namba T, Sugimoto Y, Ichikawa A and Narumiya S et al.. (1994) Molecular cloning and expression of rat prostaglandin E receptor EP2 subtype. Biochem Biophys Res Commun 200: 1329-33 [PMID:8185583]

519. Sanner JH. (1969) Antagonism of prostaglandin E2 by 1-acetyl-2-(8-chloro-10,11-dihydrodibenz $(\mathrm{b}, \mathrm{f})(1,4)$ oxazepine-10-carbonyl) hydrazine (SC-19220). Arch Int Pharmacodyn Ther 180: 46-56 [PMID:4982414]

520. Sanz C, Isidoro-García M, Dávila I, Moreno E, Laffond E, Avila C and Lorente F. (2006) Promoter genetic variants of prostanoid DP receptor (PTGDR) gene in patients with asthma. Allergy 61 : 543-8 [PMID:16629782]

521. Sarkar S, Hobson AR, Hughes A, Growcott J, Woolf CJ, Thompson DG and Aziz Q. (2003) The prostaglandin E2 receptor-1 (EP-1) mediates acid-induced visceral pain hypersensitivity in humans. Gastroenterology 124: 18-25 [PMID:12512025]

522. Sasaki Y, Usui T, Tanaka I, Nakagawa O, Sando T, Takahashi T, Namba T, Narumiya S and Nakao K. (1994) Cloning and expression of a cDNA for rat prostacyclin receptor. Biochim Biophys Acta 1224: 601-5 [PMID:7803522]

523. Sato M, Nakayama T, Soma M, Aoi N, Kosuge K, Haketa A, Izumi Y, Matsumoto K, Sato N and Kokubun S. (2007) Association between prostaglandin E2 receptor gene and essential hypertension. Prostaglandins Leukot Essent Fatty Acids 77: 15-20 [PMID:17644362]

524. Satoh H and Takeuchi K. (2012) Management of NSAID/aspirin-induced small intestinal damage by GI-sparing NSAIDs, anti-ulcer drugs and food constituents. Curr Med Chem 19: 82-9 [PMID:22300080]

525. Satoh S, Chang Cs, Katoh H, Hasegawa H, Nakamura K, Aoki J, Fujita H, Ichikawa A and Negishi M. (1999) The key amino acid residue of prostaglandin EP3 receptor for governing G protein association and activation steps. Biochem Biophys Res Commun 255: 164-8 [PMID:10082673]

526. Satoh T, Moroi R, Aritake K, Urade Y, Kanai Y, Sumi K, Yokozeki H, Hirai H, Nagata K and Hara T et al.. (2006) Prostaglandin D2 plays an essential role in chronic allergic inflammation of the skin via CRTH2 receptor. J Immunol 177: 2621-9 [PMID:16888024]

527. Savage MA, Moummi C, Karabatsos PJ and Lanthorn TH. (1993) SC-46275: a potent and highly selective agonist at the EP3 receptor. Prostaglandins Leukot Essent Fatty Acids 49: 939-43 [PMID:8140121]

528. Savonenko A, Munoz P, Melnikova T, Wang Q, Liang X, Breyer RM, Montine TJ, Kirkwood A and Andreasson K. (2009) Impaired cognition, sensorimotor gating, and hippocampal long-term depression in mice lacking the prostaglandin E2 EP2 receptor. Exp Neurol 217: 63-73 [PMID:19416671]

529. Sawyer N, Cauchon E, Chateauneuf A, Cruz RP, Nicholson DW, Metters KM, O'Neill GP and Gervais FG. (2002) Molecular pharmacology of the human prostaglandin D2 receptor, CRTH2. Br J Pharmacol 137: 1163-72 [PMID:12466225]

530. Schachar RA, Raber S, Courtney R, Zhang M and Bosworth C. (2010) Dose-Escalating, DoubleMasked, Vehicle-Controlled Trial of the IOP-Reducing Effect of EP2 Agonist, Taprenepag Isopropyl (PF-04217329). ARVO Poster: \#175/A398

531. Schlötzer-Schrehardt U, Zenkel M and Nüsing RM. (2002) Expression and localization of FP and EP prostanoid receptor subtypes in human ocular tissues. Invest Ophthalmol Vis Sci 43: $1475-87$ [PMID:11980863]

532. Schmid A, Thierauch KH, Schleuning WD and Dinter H. (1995) Splice variants of the human EP3 receptor for prostaglandin E2. Eur J Biochem 228: 23-30 [PMID:7883006]

533. Schmidt JA, Bell FM, Akam E, Marshall C, Dainty IA, Heinemann A, Dougall IG, Bonnert RV and Sargent CA. (2013) Biochemical and pharmacological characterization of AZD1981, an orally available selective DP2 antagonist in clinical development for asthma. Br J Pharmacol 168: 1626-38 [PMID:23146091]

534. Schneider A, Guan Y, Zhang Y, Magnuson MA, Pettepher C, Loftin CD, Langenbach R, Breyer RM and Breyer MD. (2004) Generation of a conditional allele of the mouse prostaglandin EP4 receptor. Genesis 40: 7-14 [PMID:15354288]

535. Schnermann J, Traynor T, Pohl H, Thomas DW, Coffman TM and Briggs JP. (2000) Vasoconstrictor responses in thromboxane receptor knockout mice: tubuloglomerular feedback and ureteral obstruction. Acta Physiol Scand 168: 201-7 [PMID:10691801]

536. Schober LJ, Khandoga AL, Dwivedi S, Penz SM, Maruyama T, Brandl R and Siess W. (2011) The role of PGE(2) in human atherosclerotic plaque on platelet $\mathrm{EP}(3)$ and $\mathrm{EP}(4)$ receptor activation and platelet function in whole blood. J Thromb Thrombolysis 32: 158-66 [PMID:21424266]

537. Schwaner I, Offermanns S, Spicher K, Seifert R and Schultz G. (1995) Differential activation of 
Gi and Gs proteins by E- and I-type prostaglandins in membranes from the human erythroleukaemia cell line, HEL. Biochim Biophys Acta 1265: 8-14 [PMID:7532011]

538. Schweda F, Klar J, Narumiya S, Nüsing RM and Kurtz A. (2004) Stimulation of renin release by prostaglandin E2 is mediated by EP2 and EP4 receptors in mouse kidneys. Am J Physiol Renal Physiol 287: F427-33 [PMID:15113745]

539. Segi E, Sugimoto Y, Yamasaki A, Aze Y, Oida H, Nishimura T, Murata T, Matsuoka T, Ushikubi F and Hirose $\mathrm{M}$ et al.. (1998) Patent ductus arteriosus and neonatal death in prostaglandin receptor EP4-deficient mice. Biochem Biophys Res Commun 246: 7-12 [PMID:9600059]

540. Seiler S, Brassard CL and Federici ME. (1990) SQ-27986 inhibition of platelet aggregation is mediated through activation of platelet prostaglandin $\mathrm{D}_{2}$ receptors. Prostaglandins 40: 119-130 [PMID:2171039]

541. Seiler SM, Brassard CL, Federici ME, Romine J and Meanwell NA. (1997) [3-[4-(4,5-Diphenyl-2oxazolyl)-5-oxazolyl]phenoxy]acetic acid (BMY 45778) is a potent non-prostanoid prostacyclin partial agonist: effects on platelet aggregation, adenylyl cyclase, cAMP levels, protein kinase, and iloprost binding. Prostaglandins 53: 21-35 [PMID:9068064]

542. Senchyna M and Crankshaw DJ. (1996) Characterization of the prostanoid TP receptor population in human nonpregnant myometrium. J Pharmacol Exp Ther 279: 262-70 [PMID:8859002]

543. Senior J, Sangha R, Baxter GS, Marshall K and Clayton JK. (1992) In vitro characterization of prostanoid FP-, DP-, IP- and TP-receptors on the non-pregnant human myometrium. $\mathrm{BrJ}$ Pharmacol 107: 215-21 [PMID:1422574]

544. Sessa WC, Halushka PV, Okwu A and Nasjletti A. (1990) Characterization of the vascular thromboxane A2/prostaglandin endoperoxide receptor in rabbit aorta. Regulation by dexamethasone. Circ Res 67: 1562-9 [PMID:2147131]

545. Sharif NA, Crider JY, Xu SX and Williams GW. (2000) Affinities, selectivities, potencies, and intrinsic activities of natural and synthetic prostanoids using endogenous receptors: focus on DP class prostanoids. J Pharmacol Exp Ther 293: 321-8 [PMID:10772998]

546. Sharif NA and Davis TL. (2002) Cloned human EP1 prostanoid receptor pharmacology characterized using radioligand binding techniques. J Pharm Pharmacol 54: 539-47 [PMID:11999132]

547. Sharif NA and Klimko PG. (2019) Prostaglandin FP receptor antagonists: discovery, pharmacological characterization and therapeutic utility. Br J Pharmacol 176: 1059-1078 [PMID:29679483]

548. Sharif NA, McLaughlin MA, Kelly CR, Xu S, Crider JY, Williams GW and Parker JL. (2006) Preclinical pharmacology of AL-12182, a new ocular hypotensive 11-oxa prostaglandin analog. $J$ Ocul Pharmacol Ther 22: 291-309 [PMID:17076623]

549. Sharif NA, Williams GW and Davis TL. (2000) Pharmacology and autoradiography of human DP prostanoid receptors using [(3)H]-BWA868C, a DP receptor-selective antagonist radioligand. $\mathrm{Br}$ J Pharmacol 131: 1025-38 [PMID:11082108]

550. Sharif NA, Xu SX, Williams GW, Crider JY, Griffin BW and Davis TL. (1998) Pharmacology of $[3 \mathrm{H}]$ prostaglandin E1/[3H]prostaglandin E2 and [3H]prostaglandin F2alpha binding to EP3 and FP prostaglandin receptor binding sites in bovine corpus luteum: characterization and correlation with functional data. J Pharmacol Exp Ther 286: 1094-102 [PMID:9694973]

551. Sheller JR, Mitchell D, Meyrick B, Oates J and Breyer R. (2000) EP(2) receptor mediates bronchodilation by PGE(2) in mice. J Appl Physiol 88: 2214-8 [PMID:10846038]

552. Shibata-Nozaki T, Ito H, Mitomi H, Akaogi J, Komagata T, Kanaji T, Maruyama T, Mori T, Nomoto S and Ozaki S et al.. (2011) Endogenous prostaglandin E2 inhibits aberrant overgrowth of rheumatoid synovial tissue and the development of osteoclast activity through EP4 receptor. Arthritis Rheum 63: 2595-605 [PMID:21898865]

553. Shichijo M, Sugimoto H, Nagao K, Inbe H, Encinas JA, Takeshita K, Bacon KB and Gantner F. (2003) Chemoattractant receptor-homologous molecule expressed on Th2 cells activation in vivo increases blood leukocyte counts and its blockade abrogates 13,14-dihydro-15-ketoprostaglandin D2-induced eosinophilia in rats. J Pharmacol Exp Ther 307: 518-25 [PMID:12975488]

554. Shioji M, Fukuda H, Kanzaki T, Wasada K, Kanagawa T, Shimoya K, Mu J, Sugimoto Y and Murata Y. (2006) Reduction of aquaporin-8 on fetal membranes under oligohydramnios in mice lacking prostaglandin F2 alpha receptor. J Obstet Gynaecol Res 32: 373-8 [PMID:16882262]

555. Siegl AM, Smith JB, Silver MJ, Nicolaou KC and Ahern D. (1979) Selective binding site for [3H]prostacyclin on platelets. J Clin Invest 63: 215-20 [PMID:372237]

556. Singh J, Zeller W, Zhou N, Hategan G, Mishra RK, Polozov A, Yu P, Onua E, Zhang J and Ramírez JL et al.. (2010) Structure-activity relationship studies leading to the identification of (2E)-3-[1-[(2,4-dichlorophenyl)methyl]-5-fluoro-3-methyl-lH-indol-7-yl]-N-[(4,5-dichloro-2thienyl)sulfonyl]-2-propenamide (DG-041), a potent and selective prostanoid EP3 receptor antagonist, as a novel antiplatelet agent that does not prolong bleeding. J Med Chem 53: 18-36 [PMID:19957930] 
557. Singh J, Zeller W, Zhou N, Hategen G, Mishra R, Polozov A, Yu P, Onua E, Zhang J and Zembower D et al.. (2009) Antagonists of the EP3 receptor for prostaglandin E2 are novel antiplatelet agents that do not prolong bleeding. ACS Chem Biol 4: 115-26 [PMID:19193156]

558. Sokolova E, Grishina Z, Bühling F, Welte T and Reiser G. (2005) Protease-activated receptor-1 in human lung fibroblasts mediates a negative feedback downregulation via prostaglandin E2. Am J Physiol Lung Cell Mol Physiol 288: L793-802 [PMID:15563688]

559. Song WL, Stubbe J, Ricciotti E, Alamuddin N, Ibrahim S, Crichton I, Prempeh M, Lawson JA, Wilensky RL and Rasmussen LM et al.. (2012) Niacin and biosynthesis of PGDaby platelet COX-1 in mice and humans. J Clin Invest 122: 1459-68 [PMID:22406532]

560. Soontrapa K, Honda T, Sakata D, Yao C, Hirata T, Hori S, Matsuoka T, Kita Y, Shimizu T and Kabashima K et al.. (2011) Prostaglandin E2-prostaglandin E receptor subtype 4 (EP4) signaling mediates UV irradiation-induced systemic immunosuppression. Proc Natl Acad Sci USA 108: 6668-73 [PMID:21460251]

561. Sparks MA, Makhanova NA, Griffiths RC, Snouwaert JN, Koller BH and Coffman TM. (2013) Thromboxane receptors in smooth muscle promote hypertension, vascular remodeling, and sudden death. Hypertension 61: 166-73 [PMID:23150508]

562. Sprague PW, Heikes JE, Gougoutas JZ, Malley MF, Harris DN and Greenberg R. (1985) Synthesis and in vitro pharmacology of 7-oxabicyclo[2.2.1] ]heptane analogues of thromboxane A2/PGH2. J Med Chem 28: 1580-90 [PMID:4067988]

563. Srinivas NR. (2015) First-in-man study of ACT-453859, a potent CRTH2 antagonist--Is the metabolite formation influenced by a polymorphic enzyme? J Clin Pharmacol 55: 1432 [PMID:26761218]

564. Stillman BA, Breyer MD and Breyer RM. (1999) Importance of the extracellular domain for prostaglandin EP(2) receptor function. Mol Pharmacol 56: 545-51 [PMID:10462542]

565. Stitham J, Arehart E, Elderon L, Gleim SR, Douville K, Kasza Z, Fetalvero K, MacKenzie T, Robb J and Martin KA et al.. (2011) Comprehensive biochemical analysis of rare prostacyclin receptor variants: study of association of signaling with coronary artery obstruction. J Biol Chem 286: 7060-9 [PMID:21189259]

566. Stitham J, Arehart E, Gleim SR, Li N, Douville K and Hwa J. (2007) New insights into human prostacyclin receptor structure and function through natural and synthetic mutations of transmembrane charged residues. Br J Pharmacol 152: 513-22 [PMID:17704830]

567. Stitham J, Stojanovic A and Hwa J. (2002) Impaired receptor binding and activation associated with a human prostacyclin receptor polymorphism. J Biol Chem 277: 15439-44 [PMID:11854299]

568. Stjernschantz J and Resul B. (1992) Phenyl substituted prostaglandin analogs for glaucoma treatment. Drugs Future 17: 691-704

569. Stocco C, Djiane J and Gibori G. (2003) Prostaglandin F(2alpha) (PGF(2alpha)) and prolactin signaling: PGF(2alpha)-mediated inhibition of prolactin receptor expression in the Corpus luteum. Endocrinology 144: 3301-3305 [PMID:12865306]

570. Stock JL, Shinjo K, Burkhardt J, Roach M, Taniguchi K, Ishikawa T, Kim HS, Flannery PJ, Coffman TM and McNeish JD et al.. (2001) The prostaglandin E2 EP1 receptor mediates pain perception and regulates blood pressure. J Clin Invest 107: 325-31 [PMID:11160156]

571. Strong P, Coleman RA and Humphrey PP. (1992) Prostanoid-induced inhibition of lipolysis in rat isolated adipocytes: probable involvement of EP3 receptors. Prostaglandins 43: 559-66 [PMID:1410520]

572. Sturino CF, O'Neill G, Lachance N, Boyd M, Berthelette C, Labelle M, Li L, Roy B, Scheigetz J and Tsou N et al.. (2007) Discovery of a potent and selective prostaglandin D2 receptor antagonist, [(3R)-4-(4-chloro-benzyl)-7-fluoro-5-(methylsulfonyl)-1,2,3,4tetrahydrocyclopenta[b]indol-3-yl]-acetic acid (MK-0524). J Med Chem 50: 794-806 [PMID:17300164]

573. Sturm EM, Schratl P, Schuligoi R, Konya V, Sturm GJ, Lippe IT, Peskar BA and Heinemann A. (2008) Prostaglandin E2 inhibits eosinophil trafficking through E-prostanoid 2 receptors. $J$ Immunol 181: 7273-83 [PMID:18981149]

574. Su X, Leon LA, Wu CW, Morrow DM, Jaworski JP, Hieble JP, Lashinger ES, Jin J, Edwards RM and Laping NJ. (2008) Modulation of bladder function by prostaglandin EP3 receptors in the central nervous system. Am J Physiol Renal Physiol 295: F984-94 [PMID:18632791]

575. Sugimoto H, Shichijo M, Iino T, Manabe Y, Watanabe A, Shimazaki M, Gantner F and Bacon KB. (2003) An orally bioavailable small molecule antagonist of CRTH2, ramatroban (BAY u3405), inhibits prostaglandin D2-induced eosinophil migration in vitro. J Pharmacol Exp Ther 305: 34752 [PMID:12649388]

576. Sugimoto H, Shichijo M, Okano M and Bacon KB. (2005) CRTH2-specific binding characteristics of $[3 \mathrm{H}]$ ramatroban and its effects on PGD2-, 15-deoxy-Delta12, 14-PGJ2- and indomethacininduced agonist responses. Eur J Pharmacol 524: 30-7 [PMID:16256979]

577. Sugimoto Y, Fukada Y, Mori D, Tanaka S, Yamane H, Okuno Y, Deai K, Tsuchiya S, Tsujimoto G and Ichikawa A. (2005) Prostaglandin E2 stimulates granulocyte colony-stimulating factor 
production via the prostanoid EP2 receptor in mouse peritoneal neutrophils. J Immunol 175: 2606-12 [PMID:16081835]

578. Sugimoto Y, Hasumoto K, Namba T, Irie A, Katsuyama M, Negishi M, Kakizuka A, Narumiya S and Ichikawa A. (1994) Cloning and expression of a cDNA for mouse prostaglandin F receptor. $J$ Biol Chem 269: 1356-60 [PMID:8288601]

579. Sugimoto Y, Nakato T, Kita A, Hatae N, Tabata H, Tanaka S and Ichikawa A. (2003) Functional domains essential for Gs activity in prostaglandin EP2 and EP3 receptors. Life Sci 74: 135-41 [PMID:14607240]

580. Sugimoto Y, Nakato T, Kita A, Takahashi Y, Hatae N, Tabata H, Tanaka S and Ichikawa A. (2004) A cluster of aromatic amino acids in the i2 loop plays a key role for Gs coupling in prostaglandin EP2 and EP3 receptors. J Biol Chem 279: 11016-26 [PMID:14699136]

581. Sugimoto Y, Namba T, Honda A, Hayashi Y, Negishi M, Ichikawa A and Narumiya S. (1992) Cloning and expression of a cDNA for mouse prostaglandin E receptor EP3 subtype. J Biol Chem 267: 6463-6 [PMID:1372606]

582. Sugimoto Y, Namba T, Shigemoto R, Negishi M, Ichikawa A and Narumiya S. (1994) Distinct cellular localization of mRNAs for three subtypes of prostaglandin E receptor in kidney. Am J Physiol 266: F823-8 [PMID:8203567]

583. Sugimoto Y and Narumiya S. (2007) Prostaglandin E receptors. J Biol Chem 282: 11613-7 [PMID:17329241]

584. Sugimoto Y, Segi E, Tsuboi K, Ichikawa A and Narumiya S. (1998) Female reproduction in mice lacking the prostaglandin $\mathrm{F}$ receptor. Roles of prostaglandin and oxytocin receptors in parturition. Adv Exp Med Biol 449: 317-21 [PMID:10026819]

585. Sugimoto Y, Shigemoto R, Namba T, Negishi M, Mizuno N, Narumiya S and Ichikawa A. (1994) Distribution of the messenger RNA for the prostaglandin E receptor subtype EP3 in the mouse nervous system. Neuroscience 62: 919-28 [PMID:7870313]

586. Sugimoto Y, Yamasaki A, Segi E, Tsuboi K, Aze Y, Nishimura T, Oida H, Yoshida N, Tanaka T and Katsuyama M et al.. (1997) Failure of parturition in mice lacking the prostaglandin F receptor. Science 277: 681-3 [PMID:9235889]

587. Sung YM, He G and Fischer SM. (2005) Lack of expression of the EP2 but not EP3 receptor for prostaglandin E2 results in suppression of skin tumor development. Cancer Res 65: 9304-11 [PMID:16230392]

588. Sung YM, He G, Hwang DH and Fischer SM. (2006) Overexpression of the prostaglandin E2 receptor EP2 results in enhanced skin tumor development. Oncogene 25: 5507-16 [PMID:16607275]

589. Suzawa T, Miyaura C, Inada M, Maruyama T, Sugimoto Y, Ushikubi F, Ichikawa A, Narumiya S and Suda T. (2000) The role of prostaglandin E receptor subtypes (EP1, EP2, EP3, and EP4) in bone resorption: an analysis using specific agonists for the respective EPs. Endocrinology 141: 1554-9 [PMID:10746663]

590. Suzuki C, Miyamoto C, Furuyashiki T, Narumiya S and Ohinata K. (2011) Central PGE2 exhibits anxiolytic-like activity via EP1 and EP4 receptors in a manner dependent on serotonin 5-HT1A, dopamine D1 and GABAA receptors. FEBS Lett 585: 2357-62 [PMID:21693121]

591. Swanson ML, Lei ZM, Swanson PH, Rao CV, Narumiya S and Hirata M. (1992) The expression of thromboxane A2 synthase and thromboxane A2 receptor gene in human uterus. Biol Reprod 47: 105-17 [PMID:1386258]

592. Swayne GT, Maguire J, Dolan J, Raval P, Dane G, Greener M and Owen DA. (1988) Evidence for homogeneity of thromboxane A2 receptor using structurally different antagonists. Eur J Pharmacol 152: 311-9 [PMID:2975605]

593. Syed NI and Jones RL. (2015) Assessing the agonist profiles of the prostacyclin analogues treprostinil and naxaprostene, particularly their $\mathrm{DP}_{1}$ activity. Prostaglandins Leukot Essent Fatty Acids 95: 19-29 [PMID:25542069]

594. Sykes D, Bradley M, Riddy D, Willard L, Powell-Herlaar E, Sandham D, Watson S, Bauer C, Dubois G and Charlton S. (2014) QAW039, a slowly dissociating CRTh2 antagonist with potential for improved clinical efficacy. Eur Respir J 44: 4074

595. Sykes DA, Bradley ME, Riddy DM, Willard E, Reilly J, Miah A, Bauer C, Watson SJ, Sandham DA and Dubois G et al.. (2016) Fevipiprant (QAW039), a Slowly Dissociating CRTh2 Antagonist with the Potential for Improved Clinical Efficacy. Mol Pharmacol 89: 593-605 [PMID:26916831]

596. Sylvia VL, Del Toro Jr F, Hardin RR, Dean DD, Boyan BD and Schwartz Z. (2001) Characterization of PGE(2) receptors (EP) and their role as mediators of 1alpha,25-(OH)(2)D(3) effects on growth zone chondrocytes. J Steroid Biochem Mol Biol 78: 261-74 [PMID:11595507]

597. Säfholm J, Dahlén SE, Delin I, Maxey K, Stark K, Cardell LO and Adner M. (2013) PGE2 maintains the tone of the guinea pig trachea through a balance between activation of contractile EP1 receptors and relaxant EP2 receptors. Br J Pharmacol 168: 794-806 [PMID:22934927]

598. Takadera T, Shiraishi Y and Ohyashiki T. (2004) Prostaglandin E2 induced caspase-dependent apoptosis possibly through activation of EP2 receptors in cultured hippocampal neurons.

Neurochem Int 45: 713-9 [PMID:15234114] 
599. Takadera T, Yumoto H, Tozuka Y and Ohyashiki T. (2002) Prostaglandin E(2) induces caspasedependent apoptosis in rat cortical cells. Neurosci Lett 317: 61-4 [PMID:11755240]

600. Takafuji V, Cosme R, Lublin D, Lynch K and Roche JK. (2000) Prostanoid receptors in intestinal epithelium: selective expression, function, and change with inflammation. Prostaglandins Leukot Essent Fatty Acids 63: 223-35 [PMID:11049698]

601. Takagi Y, Nakajima T, Shimazaki A, Kageyama M, Matsugi T, Matsumura Y, Gabelt BT, Kaufman PL and Hara H. (2004) Pharmacological characteristics of AFP-168 (tafluprost), a new prostanoid FP receptor agonist, as an ocular hypotensive drug. Exp Eye Res 78: 767-76 [PMID:15037111]

602. Takahashi N, Takeuchi K, Abe T, Sugawara A and Abe K. (1996) Immunolocalization of rat thromboxane receptor in the kidney. Endocrinology 137: 5170-3 [PMID:8895394]

603. Takahashi Y, Tokuoka S, Masuda T, Hirano Y, Nagao M, Tanaka H, Inagaki N, Narumiya S and Nagai H. (2002) Augmentation of allergic inflammation in prostanoid IP receptor deficient mice. Br J Pharmacol 137: 315-22 [PMID:12237250]

604. Takasaki I, Nojima H, Shiraki K, Sugimoto Y, Ichikawa A, Ushikubi F, Narumiya S and Kuraishi Y. (2005) Involvement of cyclooxygenase-2 and EP3 prostaglandin receptor in acute herpetic but not postherpetic pain in mice. Neuropharmacology 49: 283-92 [PMID:15925391]

605. Takayama K, García-Cardena G, Sukhova GK, Comander J, Gimbrone MA and Libby P. (2002) Prostaglandin E2 suppresses chemokine production in human macrophages through the EP4 receptor. J Biol Chem 277: 44147-54 [PMID:12215436]

606. Takayama K, Yuhki K, Ono K, Fujino T, Hara A, Yamada T, Kuriyama S, Karibe H, Okada Y and Takahata O et al.. (2005) Thromboxane A2 and prostaglandin F2alpha mediate inflammatory tachycardia. Nat Med 11: 562-6 [PMID:15834430]

607. Takechi H, Matsumura K, Watanabe Y, Kato K, Noyori R, Suzuki M and Watanabe Y. (1996) A novel subtype of the prostacyclin receptor expressed in the central nervous system. J Biol Chem 271: 5901-6 [PMID:8621463]

608. Taketo M, Rochelle JM, Sugimoto Y, Namba T, Honda A, Negishi M, Ichikawa A, Narumiya S and Seldin MF. (1994) Mapping of the genes encoding mouse thromboxane A2 receptor and prostaglandin E receptor subtypes EP2 and EP3. Genomics 19: 585-8 [PMID:7910583]

609. Taketomi Y, Ueno N, Kojima T, Sato H, Murase R, Yamamoto K, Tanaka S, Sakanaka M, Nakamura M and Nishito $\mathrm{Y}$ et al.. (2013) Mast cell maturation is driven via a group III phospholipase A2-prostaglandin D2-DP1 receptor paracrine axis. Nat Immunol 14: 554-63 [PMID:23624557]

610. Takeuchi K, Abe T, Takahashi N and Abe K. (1993) Molecular cloning and intrarenal localization of rat prostaglandin E2 receptor EP3 subtype. Biochem Biophys Res Commun 194: 885-91 [PMID:8393672]

611. Takeuchi K, Aihara E, Hayashi M and Sasaki Y. (2005) Role of prostaglandin E receptor subtypes in gastroduodenal HCO3- secretion. Med Chem 1: 395-403 [PMID:16789896]

612. Takeuchi K, Araki H, Umeda M, Komoike Y and Suzuki K. (2001) Adaptive gastric cytoprotection is mediated by prostaglandin EP1 receptors: a study using rats and knockout mice. J Pharmacol Exp Ther 297: 1160-5 [PMID:11356942]

613. Takeuchi K, Takahashi N, Abe T and Abe K. (1994) Two isoforms of the rat kidney EP3 receptor derived by alternative RNA splicing: intrarenal expression co-localization. Biochem Biophys Res Commun 199: 834-40 [PMID:8135830]

614. Takeuchi K, Takahashi N, Abe T, Ito O, Tsutsumi E, Taniyama Y and Abe K. (1994) Functional difference between two isoforms of rat kidney prostaglandin receptor EP3 subtype. Biochem Biophys Res Commun 203: 1897-903 [PMID:7945343]

615. Takeuchi K, Ukawa H, Furukawa O, Kawauchi S, Araki H, Sugimoto Y, Ishikawa A, Ushikubi F and Narumiya S. (1999) Prostaglandin E receptor subtypes involved in stimulation of gastroduodenal bicarbonate secretion in rats and mice. J Physiol Pharmacol 50: 155-67 [PMID:10424714]

616. Takeuchi K, Ukawa H, Kato S, Furukawa O, Araki H, Sugimoto Y, Ichikawa A, Ushikubi F and Narumiya S. (1999) Impaired duodenal bicarbonate secretion and mucosal integrity in mice lacking prostaglandin E-receptor subtype EP(3). Gastroenterology 117: 1128-35 [PMID:10535876]

617. Takeuchi K, Yagi K, Kato S and Ukawa H. (1997) Roles of prostaglandin E-receptor subtypes in gastric and duodenal bicarbonate secretion in rats. Gastroenterology 113: 1553-9 [PMID:9352857]

618. Tanaka A, Hattori K, Taniguchi K, Okitsu O, Tabuchi S, Nishio M, Nagakura Y, Maeda N, Murai $\mathrm{H}$ and Seki J. (2006) Replacing the cyclohexene-linker of FR181157 leading to novel IP receptor agonists: orally active prostacyclin mimetics. Part 6. Bioorg Med Chem Lett 16: 4861-4 [PMID:16837197]

619. Tanaka K, Furuyashiki T, Kitaoka S, Senzai Y, Imoto Y, Segi-Nishida E, Deguchi Y, Breyer RM, Breyer MD and Narumiya S. (2012) Prostaglandin E2-mediated attenuation of mesocortical dopaminergic pathway is critical for susceptibility to repeated social defeat stress in mice. $J$ 
Neurosci 32: 4319-29 [PMID:22442093]

620. Tanaka K, Shibuya I, Kabashima N, Ueta Y and Yamashita H. (1998) Inhibition of voltagedependent calcium channels by prostaglandin E2 in rat melanotrophs. Endocrinology 139: 480110 [PMID:9832416]

621. Tanaka Y, Furuyashiki T, Momiyama T, Namba H, Mizoguchi A, Mitsumori T, Kayahara T, Shichi $\mathrm{H}$, Kimura K and Matsuoka T et al.. (2009) Prostaglandin E receptor EP1 enhances GABAmediated inhibition of dopaminergic neurons in the substantia nigra pars compacta and regulates dopamine level in the dorsal striatum. Eur J Neurosci 30: 2338-46 [PMID:20092576]

622. Tang EH, Libby P, Vanhoutte PM and Xu A. (2012) Anti-inflammation therapy by activation of prostaglandin EP4 receptor in cardiovascular and other inflammatory diseases. J Cardiovasc Pharmacol 59: 116-23 [PMID:21697732]

623. Tang EH, Shimizu K, Christen T, Rocha VZ, Shvartz E, Tesmenitsky Y, Sukhova G, Shi GP and Libby P. (2011) Lack of EP4 receptors on bone marrow-derived cells enhances inflammation in atherosclerotic lesions. Cardiovasc Res 89: 234-43 [PMID:20736236]

624. Tang EH, Shvartz E, Shimizu K, Rocha VZ, Zheng C, Fukuda D, Shi GP, Sukhova G and Libby P. (2011) Deletion of EP4 on bone marrow-derived cells enhances inflammation and angiotensin IIinduced abdominal aortic aneurysm formation. Arterioscler Thromb Vasc Biol 31: 261-9 [PMID:21088251]

625. Theiler A, Konya V, Pasterk L, Maric J, Bärnthaler T, Lanz I, Platzer W, Schuligoi R and Heinemann A. (2016) The EP1/EP3 receptor agonist 17-pt-PGE 2 acts as an EP4 receptor agonist on endothelial barrier function and in a model of LPS-induced pulmonary inflammation. Vascul Pharmacol 87: 180-189 [PMID:27664754]

626. Theis JG, Dellweg H, Perzborn E and Gross R. (1992) Binding characteristics of the new thromboxane A2/prostaglandin H2 receptor antagonist [3H]BAY U 3405 to washed human platelets and platelet membranes. Biochem Pharmacol 44: 495-503 [PMID:1387312]

627. Thomas DW, Mannon RB, Mannon PJ, Latour A, Oliver JA, Hoffman M, Smithies O, Koller BH and Coffman TM. (1998) Coagulation defects and altered hemodynamic responses in mice lacking receptors for thromboxane A2. J Clin Invest 102: 1994-2001 [PMID:9835625]

628. Thomas DW, Rocha PN, Nataraj C, Robinson LA, Spurney RF, Koller BH and Coffman TM. (2003) Proinflammatory actions of thromboxane receptors to enhance cellular immune responses. J Immunol 171: 6389-95 [PMID:14662837]

629. Tilley SL, Audoly LP, Hicks EH, Kim HS, Flannery PJ, Coffman TM and Koller BH. (1999) Reproductive failure and reduced blood pressure in mice lacking the EP2 prostaglandin E2 receptor. J Clin Invest 103: 1539-45 [PMID:10359563]

630. Tilley SL, Hartney JM, Erikson CJ, Jania C, Nguyen M, Stock J, McNeisch J, Valancius C, Panettieri Jr RA and Penn RB et al.. (2003) Receptors and pathways mediating the effects of prostaglandin E2 on airway tone. Am J Physiol Lung Cell Mol Physiol 284: L599-606 [PMID:12618422]

631. Tippin BL, Kwong AM, Inadomi MJ, Lee OJ, Park JM, Materi AM, Buslon VS, Lin AM, Kudo LC and Karsten SL et al.. (2014) Intestinal tumor suppression in ApcMin/+ mice by prostaglandin D2 receptor PTGDR. Cancer Med 3: 1041-51 [PMID:24729479]

632. Torisu K, Kobayashi K, Iwahashi M, Nakai Y, Onoda T, Nagase T, Sugimoto I, Okada Y, Matsumoto R and Nanbu F et al.. (2004) Discovery of a new class of potent, selective, and orally active prostaglandin D2 receptor antagonists. Bioorg Med Chem 12: 5361-78 [PMID:15388164]

633. Torres D, Paget C, Fontaine J, Mallevaey T, Matsuoka T, Maruyama T, Narumiya S, Capron M, Gosset P and Faveeuw C et al.. (2008) Prostaglandin D2 inhibits the production of IFN-gamma by invariant NK T cells: consequences in the control of B16 melanoma. J Immunol 180: $783-92$ [PMID:18178816]

634. Town MH, Dournaud P, Gu Y-Z, Schonbrunn A, Mazella J, Tannenbaum GS, Casals-Stenzel J and Schillinger E. (1983) Pharmacological and cardiovascular properties of a hydantoin derivative, BW245C, with high affinity and selectivity for $\mathrm{PGD}_{2}$ receptors. Prostaglandins 25: 13-28 [PMID:6302737]

635. Toyoda Y, Morimoto K, Suno R, Horita S, Yamashita K, Hirata K, Sekiguchi Y, Yasuda S, Shiroishi M and Shimizu T et al.. (2019) Ligand binding to human prostaglandin E receptor $\mathrm{EP}_{4}$ at the lipid-bilayer interface. Nat Chem Biol 15: 18-26 [PMID:30510193]

636. Trist DG, Collins BA, Wood J, Kelly MG and Robertson AD. (1989) The antagonism by BW A868C of PGD2 and BW245C activation of human platelet adenylate cyclase. Br J Pharmacol 96: 301-6 [PMID:2466517]

637. Tsai BS, Keith RH, Perkins WE, Walsh RE, Anglin CP, Collins PW, Gasiecki AW, Bauer RF, Jones PH and Gaginella TS. (1995) Preferential binding of the novel prostaglandin SC-46275 to canine gastric versus intestinal receptors. J Pharmacol Exp Ther 275: 368-73 [PMID:7562572]

638. Tsuboi K, Iwane A, Nakazawa S, Sugimoto Y and Ichikawa A. (2003) Role of prostaglandin H2 synthase 2 in murine parturition: study on ovariectomy-induced parturition in prostaglandin $\mathrm{F}$ receptor-deficient mice. Biol Reprod 69: 195-201 [PMID:12620936]

639. Tsuboi K, Sugimoto Y, Iwane A, Yamamoto K, Yamamoto S and Ichikawa A. (2000) Uterine 
expression of prostaglandin $\mathrm{H} 2$ synthase in late pregnancy and during parturition in prostaglandin F receptor-deficient mice. Endocrinology 141: 315-24 [PMID:10614653]

640. Tsuchiya Y, Minami I, Kadotani H and Nishida E. (2005) Resetting of peripheral circadian clock by prostaglandin E2. EMBO Rep 6: 256-61 [PMID:15723041]

641. Tunaru S, Althoff TF, Nüsing RM, Diener M and Offermanns S. (2012) Castor oil induces laxation and uterus contraction via ricinoleic acid activating prostaglandin EP3 receptors. Proc Natl Acad Sci USA 109: 9179-84 [PMID:22615395]

642. Tymkewycz PM, Jones RL, Wilson NH and Marr CG. (1991) Heterogeneity of thromboxane A2 (TP-) receptors: evidence from antagonist but not agonist potency measurements. $\mathrm{BrJ}$ Pharmacol 102: 607-14 [PMID:1364826]

643. Ueno A, Matsumoto H, Naraba H, Ikeda Y, Ushikubi F, Matsuoka T, Narumiya S, Sugimoto Y, Ichikawa A and Oh-ishi S. (2001) Major roles of prostanoid receptors IP and EP(3) in endotoxininduced enhancement of pain perception. Biochem Pharmacol 62: 157-60 [PMID:11389873]

644. Ueta M, Tamiya G, Tokunaga K, Sotozono C, Ueki M, Sawai H, Inatomi T, Matsuoka T, Akira S and Narumiya S et al.. (2012) Epistatic interaction between Toll-like receptor 3 (TLR3) and prostaglandin E receptor 3 (PTGER3) genes. J Allergy Clin Immunol 129: 1413-1416.e11 [PMID:22421267]

645. Ulven T and Kostenis E. (2005) Minor structural modifications convert the dual TP/CRTH2 antagonist ramatroban into a highly selective and potent CRTH2 antagonist. J Med Chem 48: 897-900 [PMID:15715457]

646. Ulven T and Kostenis E. (2010) Novel CRTH2 antagonists: a review of patents from 2006 to 2009. Expert Opin Ther Pat 20: 1505-30 [PMID:20946089]

647. Ungrin MD, Carrière MC, Denis D, Lamontagne S, Sawyer N, Stocco R, Tremblay N, Metters KM and Abramovitz M. (2001) Key structural features of prostaglandin E(2) and prostanoid analogs involved in binding and activation of the human EP(1) prostanoid receptor. Mol Pharmacol 59: 1446-56 [PMID:11353805]

648. Unlugedik E, Alfaidy N, Holloway A, Lye S, Bocking A, Challis J and Gibb W. (2010) Expression and regulation of prostaglandin receptors in the human placenta and fetal membranes at term and preterm. Reprod Fertil Dev 22: 796-807 [PMID:20450832]

649. Urade Y and Hayaishi O. (2011) Prostaglandin D2 and sleep/wake regulation. Sleep Med Rev 15: 411-8 [PMID:22024172]

650. Ushikubi F, Aiba Y, Nakamura K, Namba T, Hirata M, Mazda O, Katsura Y and Narumiya S. (1993) Thromboxane A2 receptor is highly expressed in mouse immature thymocytes and mediates DNA fragmentation and apoptosis. J Exp Med 178: 1825-30 [PMID:8228829]

651. Ushikubi F, Hirata M and Narumiya S. (1995) Molecular biology of prostanoid receptors; an overview. J Lipid Mediat Cell Signal 12: 343-59 [PMID:8777578]

652. Ushikubi F, Segi E, Sugimoto Y, Murata T, Matsuoka T, Kobayashi T, Hizaki H, Tuboi K, Katsuyama M and Ichikawa A et al.. (1998) Impaired febrile response in mice lacking the prostaglandin E receptor subtype EP3. Nature 395: 281-4 [PMID:9751056]

653. Valentin JP, Bessac AM, Maffre M and John GW. (1996) Nitric oxide regulation of TP receptormediated pulmonary vasoconstriction in the anesthetized, open-chest rat. Eur J Pharmacol 317: 335-342 [PMID:8997619]

654. van den Brule S, Huaux F, Uwambayinema F, Ibouraadaten S, Yakoub Y, Palmai-Pallag M, Trottein F, Renauld JC and Lison D. (2014) Lung inflammation and thymic atrophy after bleomycin are controlled by the prostaglandin D2 receptor DP1. Am J Respir Cell Mol Biol 50: 212-22 [PMID:24003988]

655. Vasilache AM, Andersson J and Nilsberth C. (2007) Expression of PGE2 EP3 receptor subtypes in the mouse preoptic region. Neurosci Lett 423: 179-83 [PMID:17706357]

656. Vermylen J and Deckmyn H. (1992) Thromboxane synthase inhibitors and receptor antagonists. Cardiovasc Drugs Ther 6: 29-33 [PMID:1533533]

657. Vielhauer GA, Fujino H and Regan JW. (2004) Cloning and localization of hFP(S): a sixtransmembrane mRNA splice variant of the human FP prostanoid receptor. Arch Biochem Biophys 421: 175-85 [PMID:14984197]

658. Virgolini I, Li S, Sillaber C, Majdic O, Sinzinger H, Lechner K, Bettelheim P and Valent P. (1992) Characterization of prostaglandin (PG)-binding sites expressed on human basophils. Evidence for a prostaglandin E1, I2, and a D2 receptor. J Biol Chem 267: 12700-8 [PMID:1377673]

659. Wacker MJ, Tyburski JB, Ammar CP, Adams MC and Orr JA. (2005) Detection of thromboxane A(2) receptor mRNA in rabbit nodose ganglion neurons. Neurosci Lett 386: 121-6 [PMID:15992996]

660. Walch L, de Montpreville V, Brink C and Norel X. (2001) Prostanoid EP(1)- and TP-receptors involved in the contraction of human pulmonary veins. Br J Pharmacol 134: 1671-8 [PMID:11739243]

661. Walch L, Labat C, Gascard JP, de Montpreville V, Brink C and Norel X. (1999) Prostanoid receptors involved in the relaxation of human pulmonary vessels. Br J Pharmacol 126: 859-66 [PMID:10193765] 
662. Walsh MT and Kinsella BT. (2000) Regulation of the human prostanoid TPalpha and TPbeta receptor isoforms mediated through activation of the EP(1) and IP receptors. Br J Pharmacol 131: 601-9 [PMID:11015313]

663. Wang JW, Vu C and Poloso NJ. (2017) A Prostacyclin Analog, Cicaprost, Exhibits Potent AntiInflammatory Activity in Human Primary Immune Cells and a Uveitis Model. J Ocul Pharmacol Ther 33: 186-192 [PMID:28072560]

664. Wang L, Yao D, Deepak RNVK, Liu H, Xiao Q, Fan H, Gong W, Wei Z and Zhang C. (2018) Structures of the Human PGD $_{2}$ Receptor CRTH2 Reveal Novel Mechanisms for Ligand Recognition. Mol Cell 72: 48-59.e4 [PMID:30220562]

665. Wang W, Andersson M, Lönnroth C, Svanberg E and Lundholm K. (2005) Anorexia and cachexia in prostaglandin EP1 and EP3 subtype receptor knockout mice bearing a tumor with high intrinsic PGE2 production and prostaglandin related cachexia. J Exp Clin Cancer Res 24: 99-107 [PMID:15943039]

666. Wang X, Momota Y, Yanase H, Narumiya S, Maruyama T and Kawatani M. (2008) Urothelium EP1 receptor facilitates the micturition reflex in mice. Biomed Res 29: 105-11 [PMID:18480552]

667. Wang Y, Wos JA, Dirr MJ, Soper DL, deLong MA, Mieling GE, De B, Amburgey JS, Suchanek EG and Taylor CJ. (2000) Design and synthesis of 13,14-dihydro prostaglandin F(1alpha) analogues as potent and selective ligands for the human FP receptor. J Med Chem 43: 945-52 [PMID:10715159]

668. Ward CL, Jamieson V, Nabata T, Sharpe J, Dozono K, Suto F, Hashimoto Y and Gussak I. (2016) First Clinical Experience with ONO-4232: A Randomized, Double-blind, Placebo-controlled Healthy Volunteer Study of a Novel Lusitropic Agent for Acutely Decompensated Heart Failure. Clin Ther 38: 1109-21 [PMID:27001444]

669. Watabe A, Sugimoto Y, Honda A, Irie A, Namba T, Negishi M, Ito S, Narumiya S and Ichikawa A. (1993) Cloning and expression of cDNA for a mouse EP1 subtype of prostaglandin E receptor. $J$ Biol Chem 268: 20175-8 [PMID:7690750]

670. Watanabe K, Kawamori T, Nakatsugi S, Ohta T, Ohuchida S, Yamamoto H, Maruyama T, Kondo $\mathrm{K}$, Narumiya S and Sugimura T et al.. (2000) Inhibitory effect of a prostaglandin E receptor subtype EP(1) selective antagonist, ONO-8713, on development of azoxymethane-induced aberrant crypt foci in mice. Cancer Lett 156: 57-61 [PMID:10840160]

671. Watanabe K, Kawamori T, Nakatsugi S, Ohta T, Ohuchida S, Yamamoto H, Maruyama T, Kondo K, Ushikubi F and Narumiya S et al.. (1999) Role of the prostaglandin E receptor subtype EP1 in colon carcinogenesis. Cancer Res 59: 5093-6 [PMID:10537280]

672. Watanabe Y, Matsumura K, Takechi H, Kato K, Morii H, Björkman M, Långström B, Noyori R, Suzuki M and Watanabe Y. (1999) A novel subtype of prostacyclin receptor in the central nervous system. J Neurochem 72: 2583-92 [PMID:10349870]

673. Waxman A, Restrepo-Jaramillo R, Thenappan T, Ravichandran A, Engel P, Bajwa A, Allen R, Feldman J, Argula R and Smith P et al.. (2021) Inhaled Treprostinil in Pulmonary Hypertension Due to Interstitial Lung Disease. N Engl J Med 384: 325-334 [PMID:33440084]

674. Wei G, Kibler KK, Koehler RC, Maruyama T, Narumiya S and Doré S. (2008) Prostacyclin receptor deletion aggravates hippocampal neuronal loss after bilateral common carotid artery occlusion in mouse. Neuroscience 156: 1111-7 [PMID:18790018]

675. West JD, Voss BM, Pavliv L, de Caestecker M, Hemnes AR and Carrier EJ. (2016) Antagonism of the thromboxane-prostanoid receptor is cardioprotective against right ventricular pressure overload. Pulm Circ 6: 211-23 [PMID:27252848]

676. Wheeldon A and Vardey CJ. (1993) Characterization of the inhibitory prostanoid receptors on human neutrophils. Br J Pharmacol 108: 1051-1054 [PMID:8387383]

677. Whittle BJ, Moncada S, Mullane K and Vane JR. (1983) Platelet and cardiovascular activity of the hydantoin BW245C, a potent prostaglandin analogue. Prostaglandins 25: 205-23 [PMID:6344147]

678. Whittle BJ, Silverstein AM, Mottola DM and Clapp LH. (2012) Binding and activity of the prostacyclin receptor (IP) agonists, treprostinil and iloprost, at human prostanoid receptors: treprostinil is a potent DP1 and EP2 agonist. Biochem Pharmacol 84: 68-75 [PMID:22480736]

679. Wilson RJ, Giblin GM, Roomans S, Rhodes SA, Cartwright KA, Shield VJ, Brown J, Wise A, Chowdhury J and Pritchard S et al.. (2006) GW627368X ((N-\{2-[4-(4,9-diethoxy-1-oxo-1,3dihydro-2H-benzo[f]isoindol-2-yl)phenyl]acetyl\} benzene sulphonamide): a novel, potent and selective prostanoid EP4 receptor antagonist. Br J Pharmacol 148: 326-39 [PMID:16604093]

680. Wilson RJ and Giles H. (2005) Piglet saphenous vein contains multiple relaxatory prostanoid receptors: evidence for EP4, EP2, DP and IP receptor subtypes. Br J Pharmacol 144: 405-15 [PMID:15655509]

681. Wilson RJ, Rhodes SA, Wood RL, Shield VJ, Noel LS, Gray DW and Giles H. (2004) Functional pharmacology of human prostanoid EP2 and EP4 receptors. Eur J Pharmacol 501: 49-58 [PMID:15464062]

682. Wilson SJ, Dowling JK, Zhao L, Carnish E and Smyth EM. (2007) Regulation of thromboxane receptor trafficking through the prostacyclin receptor in vascular smooth muscle cells: role of 
receptor heterodimerization. Arterioscler Thromb Vasc Biol 27: 290-6 [PMID:17110599]

683. Wilson SJ, McGinley K, Huang AJ and Smyth EM. (2007) Heterodimerization of the alpha and beta isoforms of the human thromboxane receptor enhances isoprostane signaling. Biochem Biophys Res Commun 352: 397-403 [PMID:17134677]

684. Wilson SJ, Roche AM, Kostetskaia E and Smyth EM. (2004) Dimerization of the human receptors for prostacyclin and thromboxane facilitates thromboxane receptor-mediated cAMP generation. J Biol Chem 279: 53036-47 [PMID:15471868]

685. Wilson SM, Sheddan NA, Newton R and Giembycz MA. (2011) Evidence for a second receptor for prostacyclin on human airway epithelial cells that mediates inhibition of CXCL9 and CXCL10 release. Mol Pharmacol 79: 586-95 [PMID:21173040]

686. Wilson SM, Shen P, Rider CF, Traves SL, Proud D, Newton R and Giembycz MA. (2009) Selective prostacyclin receptor agonism augments glucocorticoid-induced gene expression in human bronchial epithelial cells. J Immunol 183: 6788-99 [PMID:19880449]

687. Wilson TW and Quest DW. (2000) Ridogrel: an antiplatelet agent with antihypertensive properties. Cardiovasc Drug Rev 18: 222-231

688. Wise H. (1998) Activation of the prostaglandin EP4-receptor subtype is highly coupled to inhibition of N-formyl-methionyl-leucyl-phenylalanine-stimulated rat neutrophil aggregation. Prostaglandins Leukot Essent Fatty Acids 58: 77-84 [PMID:9482170]

689. Wojno ED, Monticelli LA, Tran SV, Alenghat T, Osborne LC, Thome JJ, Willis C, Budelsky A, Farber DL and Artis D. (2015) The prostaglandin $\mathrm{D}_{2}$ receptor CRTH2 regulates accumulation of group 2 innate lymphoid cells in the inflamed lung. Mucosal Immunol 8: 1313-23 [PMID:25850654]

690. Wolkowicz PE, Ku DD, Grenett HE and Urthaler F. (2002) Occupation of the prostaglandin E2type 1 receptor increases rat atrial contractility via a Y-27632-sensitive pathway. Prostaglandins Other Lipid Mediat 70: 91-105 [PMID:12428681]

691. Woodward DF, Carling RW, Cornell CL, Fliri HG, Martos JL, Pettit SN, Liang Y and Wang JW. (2008) The pharmacology and therapeutic relevance of endocannabinoid derived cyclooxygenase (COX)-2 products. Pharmacol Ther 120: 71-80 [PMID:18700152]

692. Woodward DF, Fairbairn CE, Goodrum DD, Krauss AH, Ralston TL and Williams LS. (1991) $\mathrm{Ca} 2+$ transients evoked by prostanoids in Swiss 3T3 cells suggest an FP-receptor mediated response. Adv Prostaglandin Thromboxane Leukot Res 21A: 367-70 [PMID:1825572]

693. Woodward DF, Fairbairn CE, Krauss AH, Lawrence RA and Protzman CE. (1995) Radioligand binding analysis of receptor subtypes in two FP receptor preparations that exhibit different functional rank orders of potency in response to prostaglandins. J Pharmacol Exp Ther 273: 285-7 [PMID:7714778]

694. Woodward DF, Jones RL and Narumiya S. (2011) International union of basic and clinical pharmacology. LXXXIII: classification of prostanoid receptors, updating 15 years of progress. Pharmacol Rev 63: 471-538 [PMID:21752876]

695. Woodward DF, Krauss AH, Chen J, Gil DW, Kedzie KM, Protzman CE, Shi L, Chen R, Krauss HA and Bogardus A et al.. (2000) Replacement of the carboxylic acid group of prostaglandin $\mathrm{f}(2 \mathrm{alph})$ with a hydroxyl or methoxy substituent provides biologically unique compounds. $\mathrm{Br} \mathrm{J}$ Pharmacol 130: 1933-43 [PMID:10952685]

696. Woodward DF, Krauss AH, Chen J, Liang Y, Li C, Protzman CE, Bogardus A, Chen R, Kedzie KM and Krauss HA et al.. (2003) Pharmacological characterization of a novel antiglaucoma agent, Bimatoprost (AGN 192024). J Pharmacol Exp Ther 305: 772-85 [PMID:12606640]

697. Woodward DF and Lawrence RA. (1994) Identification of a single (FP) receptor associated with prostanoid-induced Ca2+ signals in Swiss 3T3 cells. Biochem Pharmacol 47: 1567-74 [PMID:8185669]

698. Woodward DF, Lawrence RA, Fairbairn CE, Shan T and Williams LS. (1993) Intraocular pressure effects of selective prostanoid receptor agonists involve different receptor subtypes according to radioligand binding studies. J Lipid Mediat 6: 545-53 [PMID:8358015]

699. Woodward DF, Liang Y and Krauss AH. (2008) Prostamides (prostaglandin-ethanolamides) and their pharmacology. Br J Pharmacol 153: 410-9 [PMID:17721551]

700. Wright DH, Ford-Hutchinson AW, Chadee K and Metters KM. (2000) The human prostanoid DP receptor stimulates mucin secretion in LS174T cells. Br J Pharmacol 131: 1537-45 [PMID:11139429]

701. Wright DH, Metters KM, Abramovitz M and Ford-Hutchinson AW. (1998) Characterization of the recombinant human prostanoid DP receptor and identification of L-644,698, a novel selective DP agonist. Br J Pharmacol 123: 1317-24 [PMID:9579725]

702. Wright DH, Nantel F, Metters KM and Ford-Hutchinson AW. (1999) A novel biological role for prostaglandin D2 is suggested by distribution studies of the rat DP prostanoid receptor. Eur J Pharmacol 377: 101-15 [PMID:10448933]

703. Xiao CY, Hara A, Yuhki K, Fujino T, Ma H, Okada Y, Takahata O, Yamada T, Murata T and Narumiya S et al.. (2001) Roles of prostaglandin I(2) and thromboxane A(2) in cardiac ischemiareperfusion injury: a study using mice lacking their respective receptors. Circulation 104: 2210- 
5 [PMID:11684633]

704. Xu HM, Wei W, Jia XY, Chang Y and Zhang L. (2007) Effects and mechanisms of total glucosides of paeony on adjuvant arthritis in rats. J Ethnopharmacol 109: 442-8 [PMID:17000070]

705. Xue L, Gyles SL, Wettey FR, Gazi L, Townsend E, Hunter MG and Pettipher R. (2005) Prostaglandin D2 causes preferential induction of proinflammatory Th2 cytokine production through an action on chemoattractant receptor-like molecule expressed on Th2 cells. J Immunol 175: 6531-6 [PMID:16272307]

706. Xue L, Salimi M, Panse I, Mjösberg JM, McKenzie AN, Spits H, Klenerman P and Ogg G. (2014) Prostaglandin D2 activates group 2 innate lymphoid cells through chemoattractant receptorhomologous molecule expressed on TH2 cells. J Allergy Clin Immunol 133: 1184-94 [PMID:24388011]

707. Yamamoto K, Suzuki T, Imamura R, Nagano T, Okabe T and Miyachi H. (2017) Synthesis of both enantiomers of 1,2,3,4-tetrahydroisoquinoline derivative IPPAM-1 and enantio-dependency of its positive allosteric modulation of prostacyclin receptor. Bioorg Med Chem Lett 27: 2567-2570 [PMID:28462839]

708. Yamane H, Sugimoto Y, Tanaka S and Ichikawa A. (2000) Prostaglandin E(2) receptors, EP2 and EP4, differentially modulate TNF-alpha and IL-6 production induced by lipopolysaccharide in mouse peritoneal neutrophils. Biochem Biophys Res Commun 278: 224-8 [PMID:11071876]

709. Yamane S, Karakawa T, Nakayama S, Nagai K, Moriyuki K, Neki S, Suto F, Kambe T, Hirota Y and Kawabata K. (2015) IOP-Lowering Effect of ONO-9054, A Novel Dual Agonist of Prostanoid EP3 and FP Receptors, in Monkeys. Invest Ophthalmol Vis Sci 56: 2547-52 [PMID:25788650]

710. Yamaoka K, Yano A, Kuroiwa K, Morimoto K, Inazumi T, Hatae N, Tabata H, Segi-Nishida E, Tanaka S and Ichikawa A et al.. (2009) Prostaglandin EP3 receptor superactivates adenylyl cyclase via the Gq/PLC/Ca2+ pathway in a lipid raft-dependent manner. Biochem Biophys Res Commun 389: 678-82 [PMID:19769944]

711. Yang H, Zhang J, Breyer RM and Chen C. (2009) Altered hippocampal long-term synaptic plasticity in mice deficient in the PGE2 EP2 receptor. J Neurochem 108: 295-304 [PMID:19012750]

712. Yang J, Xia M, Goetzl EJ and An S. (1994) Cloning and expression of the EP3-subtype of human receptors for prostaglandin E2. Biochem Biophys Res Commun 198: 999-1006 [PMID:8117308]

713. Yang L, Yamagata N, Yadav R, Brandon S, Courtney RL, Morrow JD, Shyr Y, Boothby M, Joyce S and Carbone DP et al.. (2003) Cancer-associated immunodeficiency and dendritic cell abnormalities mediated by the prostaglandin EP2 receptor. J Clin Invest 111: 727-35 [PMID:12618527]

714. Yao C, Hirata T, Soontrapa K, Ma X, Takemori H and Narumiya S. (2013) Prostaglandin E2 promotes Th1 differentiation via synergistic amplification of IL-12 signalling by cAMP and PI3kinase. Nat Commun 4: 1685 [PMID:23575689]

715. Yao C and Narumiya S. (2019) Prostaglandin-cytokine crosstalk in chronic inflammation. $B r J$ Pharmacol 176: 337-354 [PMID:30381825]

716. Yao C, Sakata D, Esaki Y, Li Y, Matsuoka T, Kuroiwa K, Sugimoto Y and Narumiya S. (2009) Prostaglandin E2-EP4 signaling promotes immune inflammation through Th1 cell differentiation and Th17 cell expansion. Nat Med 15: 633-40 [PMID:19465928]

717. Yokotani K, Nakamura K and Okada S. (2003) Prostanoid EP3 and TP receptors-mediated inhibition of noradrenaline release from the isolated rat stomach. Eur J Pharmacol 459: 187-93 [PMID:12524145]

718. Yokotani K, Nishihara M, Murakami Y, Hasegawa T, Okuma Y and Osumi Y. (1995) Elevation of plasma noradrenaline levels in urethane-anaesthetized rats by activation of central prostanoid EP3 receptors. Br J Pharmacol 115: 672-676 [PMID:7582489]

719. Yokotani K, Okada S, Nakamura K, Yamaguchi-Shima N, Shimizu T, Arai J, Wakiguchi H and Yokotani K. (2005) Brain prostanoid TP receptor-mediated adrenal noradrenaline secretion and EP3 receptor-mediated sympathetic noradrenaline release in rats. Eur J Pharmacol 512: 29-35 [PMID:15814087]

720. Yokotani K, Okuma Y and Osumi Y. (1996) Inhibition of vagally mediated gastric acid secretion by activation of central prostanoid EP3 receptors in urethane-anaesthetized rats. Br J Pharmacol 117: 653-6 [PMID:8646410]

721. Yokoyama U, Ishiwata R, Jin MH, Kato Y, Suzuki O, Jin H, Ichikawa Y, Kumagaya S, Katayama Y and Fujita T et al.. (2012) Inhibition of EP4 signaling attenuates aortic aneurysm formation. PLoS ONE 7: e36724 [PMID:22570740]

722. Yokoyama U, Iwatsubo K, Umemura M, Fujita T and Ishikawa Y. (2013) The prostanoid EP4 receptor and its signaling pathway. Pharmacol Rev 65: 1010-52 [PMID:23776144]

723. Yokoyama U, Minamisawa S, Quan H, Ghatak S, Akaike T, Segi-Nishida E, Iwasaki S, Iwamoto M, Misra S and Tamura K et al.. (2006) Chronic activation of the prostaglandin receptor EP4 promotes hyaluronan-mediated neointimal formation in the ductus arteriosus. J Clin Invest 116 : 3026-34 [PMID:17080198]

724. Yoshida K, Oida H, Kobayashi T, Maruyama T, Tanaka M, Katayama T, Yamaguchi K, Segi E, 
Tsuboyama T and Matsushita M et al.. (2002) Stimulation of bone formation and prevention of bone loss by prostaglandin E EP4 receptor activation. Proc Natl Acad Sci USA 99: 4580-5 [PMID:11917107]

725. Yoshida Y, Matsumura H, Nakajima T, Mandai M, Urakami T, Kuroda K and Yoneda H. (2000) Prostaglandin E (EP) receptor subtypes and sleep: promotion by EP4 and inhibition by EP1/EP2. Neuroreport 11: 2127-31 [PMID:10923657]

726. Young RN, Billot X, Han Y, Slipetz DA, Chauret N, Belley M, Metters K, Mathieu MC, Greig GM, Denis D and Girard M. (2004) Discovery and Synthesis of a Potent, Selective and Orally Bioavailable EP4 Receptor Agonist. Heterocycles 64: 437-446

727. Yuhki K, Ushikubi F, Naraba H, Ueno A, Kato H, Kojima F, Narumiya S, Sugimoto Y, Matsushita $\mathrm{M}$ and Oh-Ishi S. (2008) Prostaglandin I2 plays a key role in zymosan-induced mouse pleurisy. $J$ Pharmacol Exp Ther 325: 601-9 [PMID:18256172]

728. Zacharowski K, Olbrich A, Piper J, Hafner G, Kondo K and Thiemermann C. (1999) Selective activation of the prostanoid EP(3) receptor reduces myocardial infarct size in rodents. Arterioscler Thromb Vasc Biol 19: 2141-7 [PMID:10479656]

729. Zhan P, Alander C, Kaneko H, Pilbeam CC, Guan Y, Zhang Y, Breyer MD and Raisz LG. (2005) Effect of deletion of the prostaglandin EP4 receptor on stimulation of calcium release from cultured mouse calvariae: impaired responsiveness in heterozygotes. Prostaglandins Other Lipid Mediat 78: 19-26 [PMID:16303601]

730. Zhang J and Rivest S. (1999) Distribution, regulation and colocalization of the genes encoding the EP2- and EP4-PGE2 receptors in the rat brain and neuronal responses to systemic inflammation. Eur J Neurosci 11: 2651-68 [PMID:10457163]

731. Zhang M, Ho HC, Sheu TJ, Breyer MD, Flick LM, Jonason JH, Awad HA, Schwarz EM and O'Keefe RJ. (2011) EP1(-/-) mice have enhanced osteoblast differentiation and accelerated fracture repair. J Bone Miner Res 26: 792-802 [PMID:20939055]

732. Zhang Y, Guan Y, Schneider A, Brandon S, Breyer RM and Breyer MD. (2000) Characterization of murine vasopressor and vasodepressor prostaglandin E(2) receptors. Hypertension 35: 112934 [PMID:10818076]

733. Zhang Z and Yin H. (2002) Detection of EP1 and FP receptor mRNAs in the iris-ciliary body using in situ hybridization. Chin Med J (Engl) 115: 1226-1228 [PMID:12215298]

734. Zhen G, Kim YT, Li RC, Yocum J, Kapoor N, Langer J, Dobrowolski P, Maruyama T, Narumiya S and Doré S. (2012) PGE2 EP1 receptor exacerbated neurotoxicity in a mouse model of cerebral ischemia and Alzheimer's disease. Neurobiol Aging 33: 2215-9 [PMID:22015313]

735. Zheng Y, Ritzenthaler JD, Sun X, Roman J and Han S. (2009) Prostaglandin E2 stimulates human lung carcinoma cell growth through induction of integrin-linked kinase: the involvement of EP4 and Sp1. Cancer Res 69: 896-904 [PMID:19176380]

736. Zhou W, Blackwell TS, Goleniewska K, O'Neal JF, Fitzgerald GA, Lucitt M, Breyer RM and Peebles RS. (2007) Prostaglandin I2 analogs inhibit Th1 and Th2 effector cytokine production by CD4 T cells. J Leukoc Biol 81: 809-17 [PMID:17135575]

737. Zhou W, Dowell DR, Huckabee MM, Newcomb DC, Boswell MG, Goleniewska K, Lotz MT, Toki S, Yin H and Yao S et al.. (2012) Prostaglandin I2 signaling drives Th17 differentiation and exacerbates experimental autoimmune encephalomyelitis. PLoS ONE 7: e33518 [PMID:22590492]

738. Zhou W, Goleniewska K, Zhang J, Dulek DE, Toki S, Lotz MT, Newcomb DC, Boswell MG, Polosukhin VV and Milne GL et al.. (2014) Cyclooxygenase inhibition abrogates aeroallergeninduced immune tolerance by suppressing prostaglandin I2 receptor signaling. J Allergy Clin Immunol 134: 698-705.e5 [PMID:25042746]

739. Zhu S, Xue R, Zhao P, Fan FL, Kong X, Zheng S, Han Q, Zhu Y, Wang N and Yang J et al.. (2011) Targeted disruption of the prostaglandin E2 E-prostanoid 2 receptor exacerbates vascular neointimal formation in mice. Arterioscler Thromb Vasc Biol 31: 1739-47 [PMID:21636806] 